\title{
Special Analysis for Disposal of High-Concentration l-129 Waste in the Intermediate-Level Vaults at the E-Area Low-Level Waste Facility
}

by

L. B. Collard

Westinghouse Savannah River Company

Savannah River Site

Aiken, South Carolina 29808

This paper was prepared in connection with work done under the above contract number with the U.S. Department of Energy. By acceptance of this paper, the publisher and/or recipient acknowledges the U. S. Government's right to retain a nonexclusive, royalty-free license in and to any copyright covering this paper, along with the right to reproduce and to authorize others to reproduce all or part of the copyrighted paper. 


\section{DISCLAIMER}

This report was prepared as an account of work sponsored by an agency of the United States Government. Neither the United States Government nor any agency thereof, nor any of their employees, makes any warranty, express or implied, or assumes any legal liability or responsibility for the accuracy, completeness, or usefulness of any information, apparatus, product or process disclosed, or represents that its use would not infringe privately owned rights. Reference herein to any specific commercial product, process or service by trade name, trademark, manufacturer, or otherwise does not necessarily constitute or imply its endorsement, recommendation, or favoring by the United States Government or any agency thereof. The views and opinions of authors expressed herein do not necessarily state or reflect those of the United States Government or any agency thereof.

This report has been reproduced directly from the best available copy.

Available for sale to the public, in paper, from: U.S. Department of Commerce, National Technical Information Service, 5285 Port Royal Road, Springfield, VA 22161, phone: (800) 553-6847

fax: (703) 605-6900

email: orders@ntis.fedworld.gov

online ordering: http://www.ntis.gov/ordering.htm

Available electronically at http://www.doe.gov/bridge

Available for a processing fee to U.S. Department of Energy and its contractors, in paper, from: U.S. Department of Energy, Office of Scientific and Technical Information, P.O. Box 62, Oak Ridge, TN 37831-0062, phone: (865) 576-8401

fax: (865) $576-5728$

email: reports@adonis.osti.gov 


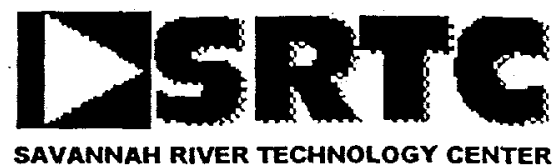

July 27,2000

TO:

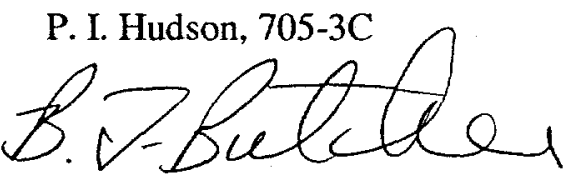

FROM: $\quad$ B. T. Butcher, 773-43A (x5-5810)

\section{TRANSMITTAL OF FINAL SPECIAL ANALYSIS FOR DISPOSAL OF HIGH-} CONCENTRATION 1-129 WASTE IN THE INTERMEDIATE LEVEL VAULT (ILV)

Attached is revision 1 of the report entitled, "Special Analysis for Disposal of High-

Concentration I-129 Waste in the Intermediate Level Vaults at the E-Area Low-Level Waste Facility", WSRC-RP-99-01070, Rev, 1, 7/31/00. This performance assessment special analysis formally documents work performed by SRTC in FY 99 on disposal of I-129 bearing wastewater treatment media and residues in the IL Vault. This revision was prepared to address comments from DOE-SR that arose following publication of revision 0 .

Att.

P.I. Hudson, 703-5C (10 copies)

W.T. Goldston, 703-5C

A.W. Wiggins, $241-246 \mathrm{H}$

C.A. Lucha, 704-22G

W.E. Stevens, 773-A

B.T. Butcher, 773-43A

L.B. Collard, 773-43A

J.R. Cook, 773-43A

D.I. Kaplan, 773-43A

E.L. Wilhite, 773-43A

STI, 4 copies, 703-43A

WPT File, 773-43A 
WSRC-RP-99-01070

\section{SPECIAL ANALYSIS FOR \\ DISPOSAL OF HIGH-CONCENTRATION I-129 WASTE IN THE INTERMEDIATE-LEVEL VAULTS AT THE E-AREA LOW- LEVEL WASTE FACILITY}

Prepared by:

Leonard B. Collard

July 31,2000

Rev. 1

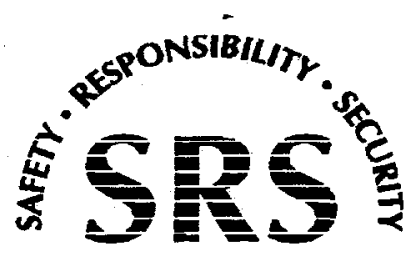


Key Words: I-129 Intermediate Level Vault Performance Assessment

\section{SPECIAL ANALYSIS FOR \\ DISPOSAL OF HIGH-CONCENTRATION I-129 WASTE IN THE INTERMEDIATE-LEVEL VAULTS AT THE E-AREA LOW- LEVEL WASTE FACILITY}

Prepared by:

Leonard B. Collard

July 31,2000

Rev. 1 
ii

WSRC-RP-99-01070

REVIEWS AND APPROVALS

Author

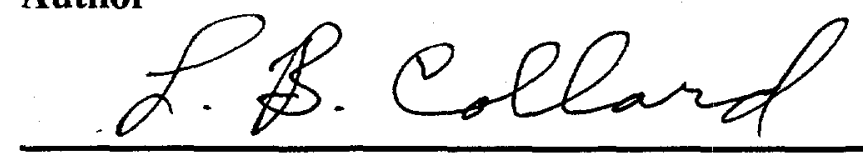

$7 / 26100$

Leonard B. Collard, Waste Processing Technology

Date

Design Check 8. Dilhite

E.L. Wilhite, Waste Processing Technology

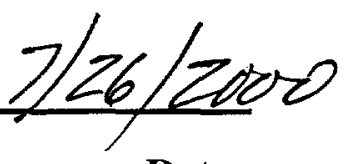

(per Manual E7, Procedure 2.40)

Date
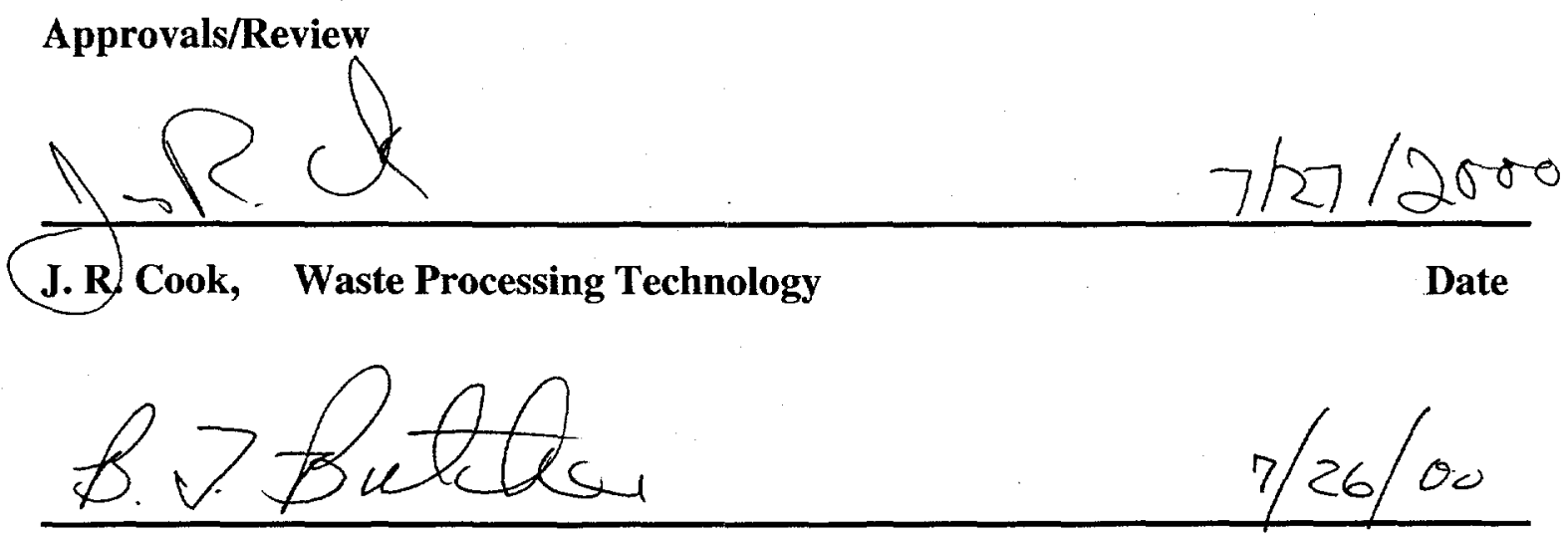

B.T. Butcher, Level 4 Manager, Waste Processing Technology

Date

Pgitudson pf wT EoLDSTON $2 / 26 / 00$

W.T. Goldston, SW Technology and Integration

Date

Rev. 1

July 31,2000 


\section{DISCLAIMER}

This report was prepared as an account of work sponsored by an agency of the United States Government. Neither the United States Government nor any agency thereof, nor any of their employees, make any warranty, express or implied, or assumes any legal liability or responsibility for the accuracy, completeness, or usefulness of any information, apparatus, product, or process disclosed, or represents that its use would not infringe privately owned rights. Reference herein to any specific commercial product, process, or service by trade name, trademark, manufacturer, or otherwise does not necessarily constitute or imply its endorsement, recommendation, or favoring by the United States Government or any agency thereof. The views and opinions of authors expressed herein do not necessarily state or reflect those of the United States Government or any agency thereof. 


\section{DISCLAIMER}

Portions of this document may be illegible in electronic image products. Images are produced from the best available original document. 
TABLE OF CONTENTS

SECTION 1 EXECUTIVE SUMMARY

1. EXECUTIVE SUMMARY.............................................................................................1-3

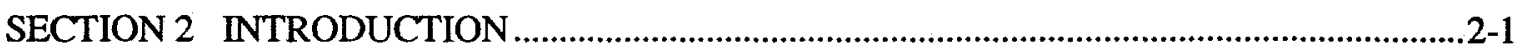

2. INTRODUCTION

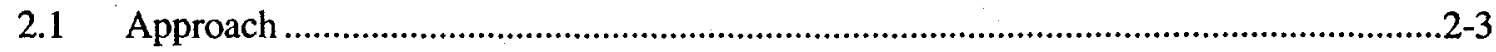

2.2 General Facility Description ....................................................................................2-3

2.2.1 High-Concentration I-129 Waste Disposal in Intermediate-Level Vaults ................2-4

2.2.1.1 Description and Location ..................................................................................2-4

2.2.1.2 Major Design Philosophy ...........................................................................2-4

2.2.1.3 Facility Features ..............................................................................................2-7

2.2.1.4 Waste Characteristics .................................................................................2-8

2.2.1.5 Disposal Concept Considerations and Movement of Waste Through the

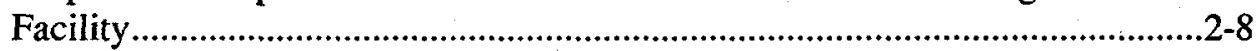

2.2.1.6 Waste Acceptance and Certification .................................................................2-9

2.2.1.7 Land Use Patterns...................................................................................

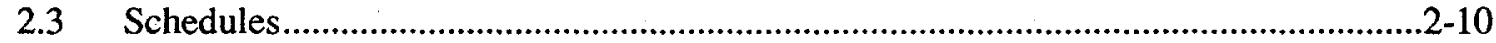

2.3.1 Operation/Waste Receipt.................................................................................2-10

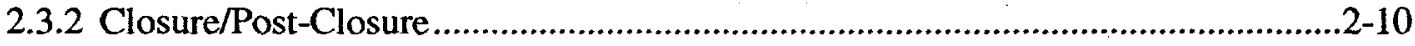

$2.4 \quad$ Related Documents..............................................................................................2-10

2.4.1 Revised Performance Assessment for the E-Area Low-Level Waste Facility .......2-10

2.5 Performance Criteria .............................................................................................2-10

2.6 Summary of Key Assessment Assumptions …………..................................................2-10

SECTION 3 DISPOSAL FACILITY CHARACTERISTICS .........................................................3-1

3. DISPOSAL FACILITY CHARACTERISTICS ................................................................3-3

3.1 Site Characteristics ............................................................................................3-3

3.2 Principal Facility Design Features...........................................................................3-3

3.2.1 Intermediate-Level Vault Closure Concept ..................................................................3-3

3.2.1.1 Water Infiltration and Disposal Unit Cover Integrity.......................................3-3

3.2.1.2 Structural Stability and Inadvertent Intruder Barrier.............................................3-5

3.3 Waste Characteristics .................................................................................................

3.3.1 Intermediate-Level Vaults ........................................................................................

3.3.1.1 Waste Type/Chemical and Physical Form.......................................................

3.3.1.2 Radionuclide Inventory ……......................................................................6-6

3.3.1.3 Waste Volume .......................................................................................................

3.3.1.4 Packaging Criteria ..............................................................................................

3.3.1.5 Pre-Disposal Treatment Methods ........................................................................

3.3.1.6 Waste Acceptance Restrictions ..........................................................................3-7

SECTION 4 ANALYSIS OF PERFORMANCE ………………..................................................

4. ANALYSIS OF PERFORMANCE ...............................................................................4-3

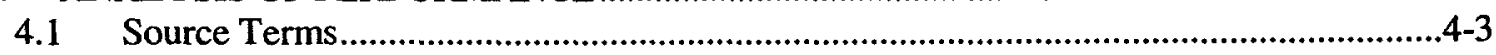

4,1.1 All-Pathways Analysis .............................................................................................4-3

4.1.2 Air Pathways Analysis ………………………………...........................................4-4 


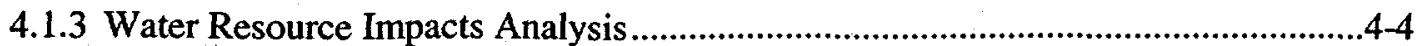

4.1.3.1 Conceptual Model of the Source Term ...........................................................4-4

4.1.3.1.1 Radionuclide Inventory .........................................................................4-4

4.1.3.1.2 Rate of Water Infiltration into Disposal Units .............................................4-4

4.1.3.1.3 Integrity of Barriers to Resist Water Intrusion .............................................4-5

4.1.3.1.4 Composition of Infiltrating Water..........................................................4-6

4.1.3.1.5 Physical/chemical characteristics .............................................................4-6

4.1.3.2 Estimated Releases of Radionuclides............................................................4-8

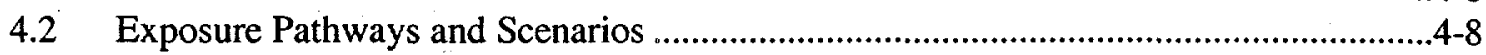

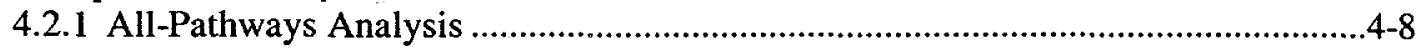

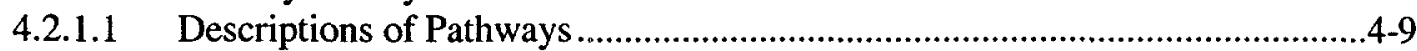

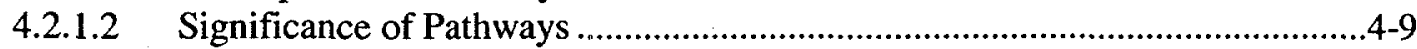

4.2.1.3 Special Considerations for Pathways ...........................................................4-12

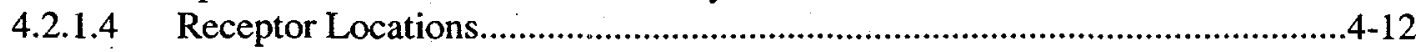

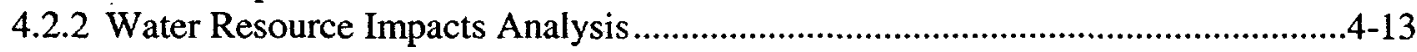

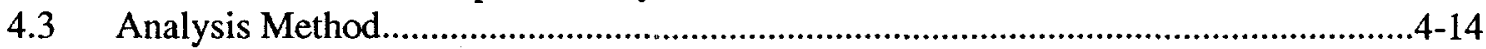

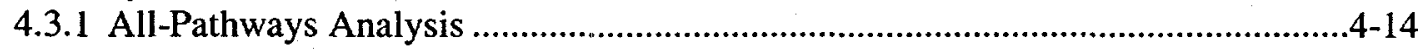

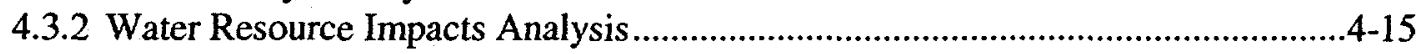

4.3.2.1 Vadose Zone Model of IL Vaults .............................................................4-15

4.3.2.2 Saturated Zone Model of E Area ...........................................................4-20

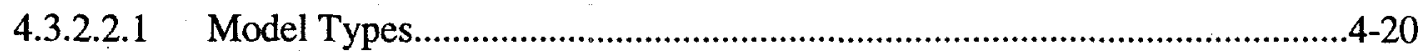

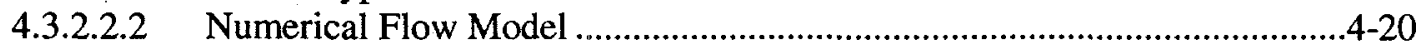

4.3.2.2.3 Numerical Transport Model ...................................................................20

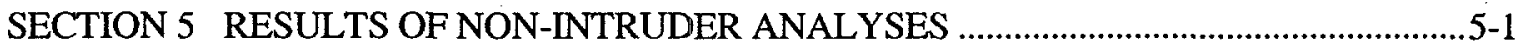

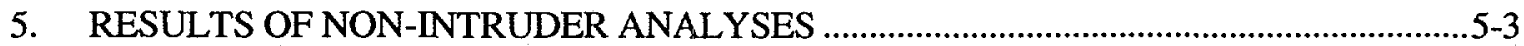

5.1 Results of All-Pathways Analysis and Water Resource Impacts Analysis ....................5-3

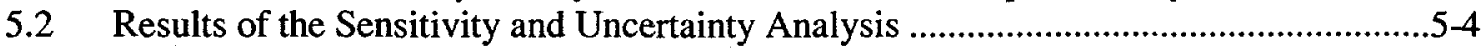

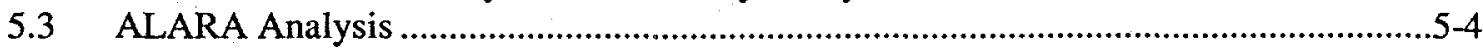

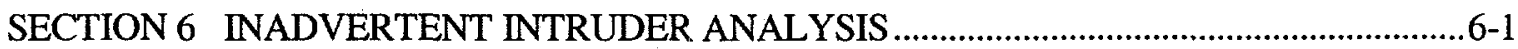

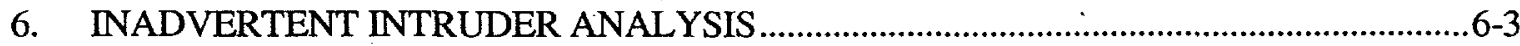

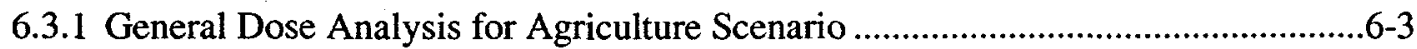

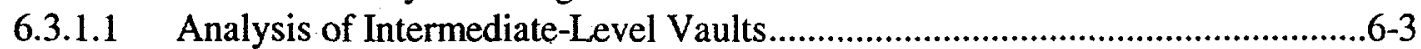

6.3.2 General Dose Analysis for Resident Scenario ..................................................6-5

6.3.2.1 Analysis of Intermediate-Level Vaults..........................................................6-6

6.3.3 Dose Analysis for Post-Drilling Scenario .............................................................6-8

6.4 Sensitivity and Uncertainty in Dose Models for Inadvertent Intruders ..........................6-8

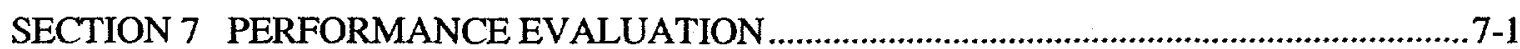

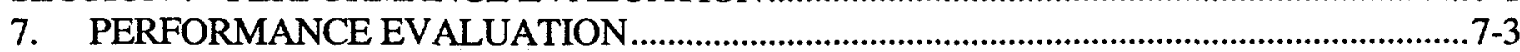

7.1 Comparison of Results to Performance Objectives and Requirements .........................7-3

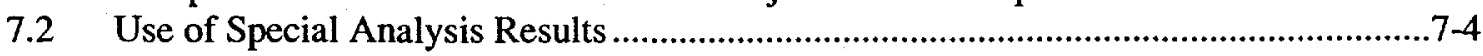

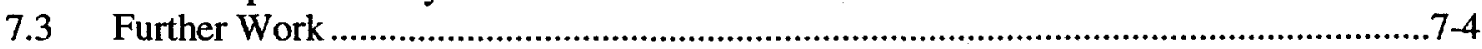

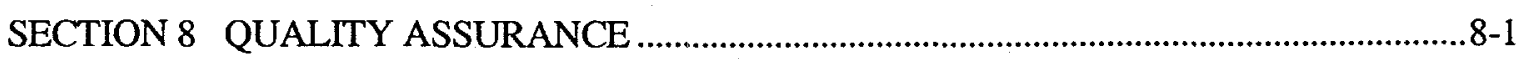

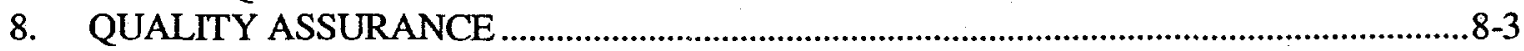


SECTION 9 LIST OF PREPARERS $9-1$

9. LIST OF PREPARERS

SECTION 10 REFERENCES

$10-1$

10. REFERENCES

APPENDIX A PROJECTED INVENTORY FOR HIGH-CONCENTRATION I-129 WASTE

A-1

APPENDIX B SUPPORTING DETAILS OF MODELS AND ASSUMPTIONS

B-1

APPENDIX C RESULTS OF FLOW AND TRANSPORT MODELING C-1 


\section{LIST OF TABLES}

Table 3.2-1

Table 4.1-3

Table 4.1-5

Table 4.2-3

Table 4.3-1

Table 4.3-2

Table 4.3-3

Table 5.1-1

Table 5.1-2

Table 5.1-3

Table 6.3-1

Table 6.3-2

Table 6.3-3

Table 7.1-1

Table A.1

Table B.3-1

Table B.3-2

Table B.3-3

Table B.3-4

Table B.3-5

Table B.3-6

Table B.3-7

Table B.3-8

Table B.3-9

Table B.3-10
Values for hydraulic properties of vault closure design 3-5

Elemental Sorption Coefficients $\left(\mathrm{K}_{d} \mathrm{~s}\right)$ for I-129 in IL Vaults 4-7

Diffusion Coefficients Assumed for Mass Transport Simulations -4-8 Maximum Contaminant Levels for Radionuclides in Groundwater Corresponding to Different Options for Groundwater Protection Requirements $4-14$ Comparison of MCLs and Allowable Groundwater Concentrations Based on the 25 mrem Per Year Performance Objective for Off-Site Individuals 4-14 Hydraulic Conductivity, Porosity, and Characteristics of Materials in IL Vault Conceptual Model.

Estimated Peak Fractional Flux to the Water Table for I-129 Waste Forms .......4-20 Annual EDEs from Drinking Water Pathway Per Unit Concentration of Radionuclides in Water.

Peak Groundwater Concentrations for the High-Concentration I-129 Waste

Simulations.

Calculated I-129 Inventory Limits for One IL Vault Based on the Groundwater

Pathway $.5-5$

Intruder-Based I-129 Disposal Limits for IL Vaults - Agriculture Scenario at 20,000 Years

Intruder-Based I-129 Disposal Limits for IL vaults - Resident Scenario at 100 Years.

Intruder-Based I-129 Disposal Limits for IL vaults - Resident Scenario at 10,000 years

IL Vaults: High-Concentration I-129 Waste Inventory Limits, Limiting

Pathway, and Comparison to Projected Inventory.

Projected Inventory for High-Concentration I-129 Waste Considered for Disposal in the IL Vaults

Radionuclides Considered in Dose Analyses for Off-Site Individuals or Inadvertent Intruders B-3

Internal Dose Conversion Factors (DCFs) for Ingestion and Inhalation of Radionuclides.

External Dose-Rate Conversion Factors for Radionuclides Uniformly Distributed

in $15 \mathrm{~cm}$ of Surface Soil B-4

External Dose-Rate Conversion Factors for Radionuclides Uniformly Distributed in Infinite Thickness of Soil-Equivalent Material. B-4

Annual EDEs from Drinking Water Pathway per Unit Concentration of Radionuclides in Water... B-4

Elemental Plant-to-Soil Concentration Ratios in Vegetables. B-5 Annual EDEs from Vegetable Pathway Per Unit Concentration of Radionuclides in Exhumed Waste for Agriculture Scenario.

Annual EDEs from Soil Ingestion Pathway Per Unit Concentration of Radionuclides in Exhumed Waste for Agriculture Scenario

Annual EDEs from External Exposure in Vegetable Garden Per Unit Concentration of Radionuclides in Exhumed Waste for Agriculture Scenario.

Annual EDEs from External Exposure in Home Per Unit Concentration of Radionuclides in Disposal Units for Agriculture Scenario. 
Table B.3-11 Annual EDEs from Inhalation Exposure in Vegetable Garden Per Unit Concentration of Radionuclides in Exhumed Waste for Agriculture

Scenario. B-5

Table B.3-12 Annual EDEs from Inhalation Exposure in Home per Unit Concentration of Radionuclides in Disposal Units for Agriculture Scenario.

Table B.3-13 Annual EDEs Per Unit Concentration of Radionuclides in Disposal Units from All Exposure Pathways for Agriculture Scenario.

B-6

Table B.3-14 Annual EDEs Per Unit Concentration of Radionuclides in Disposal Units for Resident Scenario B-6

Table B.3-15 Annual EDEs Per Unit Concentration of Radionuclides in Exhumed Waste for Post-Drilling Scenario B-6

Table B.3-16 Summary of All Scenario Dose Conversion Factors (SDCF) for I-129 for Inadvertent Intruder Cases

Table B.3-17 Summary of Radionuclide-Independent Parameter Values Used in Dose Analyses for Off-Site Individuals and Inadvertent Intruders B-8 


\section{LIST QF FIGURES}

Figure 2.2-1 Projected Layout of the E-Area Low-Level Waste Facility $2-5$

Figure 2.2-2

Arrangement of the Intermediate Level Non-Tritium and Intermediate Level

Tritium Vaults $.2-6$

Figure 3.2-1

Figure 4.2-1

Figure 4.3-1

Figure 4.3-2

Figure 4.3-5

Figure 5.1-1

Figure C-1

Vault closure concept (intact cover system)

Pathways to Human Receptors from Subsurface Radionuclides .........................4-10

Conceptual Model of IL vault .....................................................................17

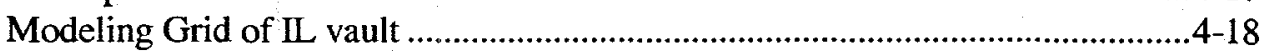

Location of the IL Vaults..............................................................................

Inventory Limits as a Function of Kd ................................................................5-6

Hypothetical Waste $(\mathrm{Kd}=2 \mathrm{ml} / \mathrm{g})$ : PORFLOW Predicted I- 129 Fractional Release

$\mathrm{Ci} /$ year/Ci Inventory) to the Water Table and Normalized Concentration

(pCi/Liter/Ci Inventory) at the 100-meter Well for the Intermediate Level Vaults....

Figure C-2 Hypothetical Waste (Kd=20 ml/g): PORFLOW Predicted I-129 Fractional Release

$\mathrm{Ci} /$ year/Ci Inventory) to the Water Table and Normalized Concentration (pCi/Liter/Ci Inventory) at the 100-meter Well for the Intermediate Level Vaults....

Figure C-3 Hypothetical Waste $(\mathrm{Kd}=200 \mathrm{ml} / \mathrm{g})$ : PORFLOW Predicted I-129 Fractional C-4 Release $\mathrm{Ci} /$ year/Ci Inventory) to the Water Table and Normalized Concentration (pCi/Liter/Ci Inventory) at the 100-meter Well for the Intermediate Level Vaults....

Figure C-4

Activated Carbon $(\mathrm{Kd}=600 \mathrm{ml} / \mathrm{g})$ : PORFLOW Predicted I-129 Fractional Release $\mathrm{Ci} /$ year/Ci Inventory) to the Water Table and Normalized Concentration (pCi/Liter/Ci Inventory) at the 100-meter Well for the Intermediate Level Vaults....

Figure C-5

Hypothetical Waste $(\mathrm{Kd}=1000 \mathrm{ml} / \mathrm{g})$ : PORFLOW Predicted I-129 Fractional Release $\mathrm{Ci} /$ year/Ci Inventory) to the Water Table and Normalized Concentration (pCi/Liter/Ci Inventory) at the 100-meter Well for the Intermediate Level Vaults....

Figure C-6

Dowex $21 \mathrm{~K}$ Resin $(\mathrm{Kd}=2800 \mathrm{ml} / \mathrm{g})$ : PORFLOW Predicted I-129 Fractional Release $\mathrm{Ci} /$ year/Ci Inventory) to the Water Table and Normalized Concentration (pCi/Liter/Ci Inventory) at the 100-meter Well for the Intermediate Level Vaults....

Figure C-7

Hypothetical Waste $(\mathrm{Kd}=2000 \mathrm{~m} / \mathrm{g})$ : PORFLOW Predicted I-129 Fractional Release $\mathrm{Ci} /$ year/Ci Inventory) to the Water Table and Normalized Concentration ( $\mathrm{pCi} /$ Liter/Ci Inventory) at the 100-meter Well for the Intermediate Level Vaults....

Figure C-8 GT-73 (Kd=3100 ml/g): PORFLOW Predicted I-129 Fractional Release $\mathrm{Ci} /$ year/Ci Inventory) to the Water Table and Normalized Concentration (pCi/Liter/Ci Inventory) at the 100-meter Well for the Intermediate Level Vaults.... 


\section{LIST OF ACRONYMS \& ABBREVIATIONS}

\begin{tabular}{|c|c|}
\hline $3 \mathbf{D}$ & three dimensional \\
\hline$\rho_{b}$ & dry bulk density \\
\hline$\rho_{\mathrm{s}}$ & particle density \\
\hline ACRI & Analytical and Computational Research, Inc. \\
\hline ALARA & as low as reasonably achievable \\
\hline ANSI & American National Standards Institute \\
\hline ARAR & applicable or relevant and appropriate requirement \\
\hline ASL & above sea level \\
\hline ASME & American Society of Mechanical Engineers \\
\hline $\mathbf{A T}$ & advanced tensiometer \\
\hline BNFL & British Nuclear Fuels Company \\
\hline${ }^{\circ} \mathrm{C}$ & degrees Centigrade \\
\hline $\mathbf{C A}$ & Composite Analysis \\
\hline CAS & Computer Applications Specialist \\
\hline ce & cubic centimeters \\
\hline CERCLA & Comprehensive Environmental Response, Compensation, and Liability Act \\
\hline CEWU & cement-stabilized encapsulated waste unit \\
\hline CFR & Code of Federal Regulations \\
\hline cfs & cubic feet per second \\
\hline $\mathbf{C i}$ & curie 1 the \\
\hline $\mathbf{C i} / \mathbf{y}-\mathbf{C i}$ & curies per year per curies disposed \\
\hline cm & centimeter \\
\hline $\mathbf{c m} / \mathbf{y}$ & centimeters per year \\
\hline cpu & central processor unit \\
\hline CSEW & cement-stabilized encapsulated waste \\
\hline CRSA & Central Savannah River Area \\
\hline$+\mathbf{d}$ & signifies that a radionuclide has potentially significant daughters \\
\hline DCF & dose conversion factor \\
\hline DCG & DOE Derived Concentration Guide \\
\hline DOC & U.S. Department of Commerce \\
\hline DOE & U.S. Department of Energy \\
\hline $\mathbf{D} / \mathbf{Q}$ & relative deposition \\
\hline DWPF & Defense Waste Processing Facility (at the SRS) \\
\hline DWS & drinking water standards \\
\hline & exponential notation (e.g., $5 E-10=5 \times 10^{-10}=0.0000000005$ ). \\
\hline EDE & effective dose equivalent \\
\hline EH & U.S. DOE Office of Environment, Safety, and Health \\
\hline EIS & Environmental Impact Statement \\
\hline EMOP & E-Area Monitoring Program \\
\hline EPA & U.S. Environmental Protection Agency \\
\hline ETF & Effluent Treatment Facility \\
\hline${ }^{\circ} \mathbf{F}$ & degrees Fahrenheit \\
\hline FACT & Flow and Contaminant Transport Model \\
\hline FEMWASTE & Finite-Element Model of Waste Transport \\
\hline FLASH & Finite Element Computer Code for Variably Saturated Flow \\
\hline ft & feet \\
\hline FY & fiscal year \\
\hline g. & gram \\
\hline
\end{tabular}


GSA

h

HTO

ICRP

IL

in

INEEL

$\mathbf{K}_{\mathbf{d}}$

$\mathbf{K}_{\mathbf{v}}$

$\mathrm{kg}$

$\mathrm{kg} \mathrm{m}^{-2} \mathrm{yr}^{-1}$

km

$\mathbf{k m}^{2}$

L

LAW

L/d

LHS

LLD

LLW

LLWF

M

m

MAP

MCL

MEXAMS

$\mu \mathrm{Ci}$

$\mu \mathrm{g}$

$\mu \mathrm{S} / \mathrm{cm}$

mg

$\mathbf{m L}$

MMI

MPC

mrem

msl

$\mathrm{nCi}$

NPDES

NPL

NQA

NRC

NTU

NWS

ORNL

ORWBG

PA

pc

PCCG

pCi

PI

PNL

QA

RAM
General Separations Area (at the SRS)

hour

tritiated water vapor

International Commission on Radiological Protection

intermediate level

inches

Idaho National Engineering and Environmental Laboratory

sorption coefficient

vertical hydraulic conductivity coefficient

kilograms

kilograms per square meter per year

kilometers

square kilometers

liters

low-activity waste

liters per day

Latin Hypercube Sample

lower limit of detection

low-level waste

Low-Level Waste Facility

moles

meters

PA Maintenance Program

maximum contaminant level

Metals Exposure Analysis Modeling System

microcuries

micrograms

microsiemens per centimeter

milligrams

milliliters

Modified Mercalli Intensity

maximum permissible concentration

millirems

mean sea level

nanocuries

National Pollutant Discharge Elimination System

National Priorities List

Nuclear Quality Assurance

U.S. Nuclear Regulatory Commission

nephelometric turbidity units

National Weather Service

Oak Ridge National Laboratory

Old Radiological Waste Burial Ground (at the SRS)

performance assessment

personal computer

Preconditioned Conjugate Gradient

picocuries

principal investigator

Pacific Northwest Laboratory

quality assurance

random-access memory 


\begin{tabular}{ll} 
RCRA & Resource Conservation and Recovery Act \\
R\&D & research and development \\
\%ROI & percent region of influence \\
RPA & Radiological performance assessment \\
S. or sec & second \\
SA & Special Analysis \\
SAFT3D & Subsurface Analysis Finite Element Model for Flow and Transport in 3 \\
SAR & Dimensions \\
SCDHEC & Safety Analysis Report \\
SDCF & South Carolina Department of Health and Environmental Control \\
SMCL & scenario dose conversion factor \\
SQA & Secondary Maximum Contaminant Level \\
SQC & software quality assurance \\
SRS & software quality control \\
SRTC & Savannah River Site \\
SWD & Savannah River Technology Center \\
T12 & Solid Waste Department of WSRC \\
TDR & halflife \\
U.S & Time-domain reflectometer \\
USDA & United States \\
USGS & U.S. Department of Agriculture \\
UTR & U.S. Geological Survey \\
VAM3DCG & Upper Three Runs \\
& Variably Saturated Analysis Model in Three Dimensions with Preconditioned \\
VZMS & Conjugate Gradient Matrix Solvers \\
WAC & Vadose zone monitoring system \\
WITS & waste acceptance criteria \\
WQS & Waste Information Tracking System \\
WSRC & water quality standard \\
X/Q & Westinghouse Savannah River Company \\
y or yr & relative concentration \\
& year \\
\hline
\end{tabular}


THIS PAGE INTENTIONALLY LEFT BLANK

Rev. 1 
SECTION 1

EXECUTIVE SUMMARY

Rev. 1 
THIS PAGE INTENTIONALLY LEFT BLANK

Rev. 1

July 31,2000 


\section{EXECUTIVE SUMMARY}

This revision was prepared to address comments from DOE-SR that arose following publication of revision 0. This Special Analysis (SA) addresses disposal of high-concentration I-129 wastes in the Intermediate Level (IL) Vaults at the Savannah River Site E-Area Low-Level Waste Facility. This SA addresses both the existing activated carbon vessels already placed in the $\mathbb{I}$ Vault and any type of future waste that contains a high-concentration of I-129. An equation is developed that relates a waste form's vault inventory limit of I-129 to the waste form's measured $\mathrm{K}_{\mathrm{d}}$.

This SA was prepared to meet the requirements of the U.S. Department of Energy Order 435.1 (DOE 1999a). The Order specifies that a performance assessment or SA should provide reasonable assurance that a low-level waste disposal facility will comply with the performance objectives of the Order. The performance objectives require that:

- Dose to representative members of the public shall not exceed 25 mrem $(0.25 \mathrm{mSv})$ in a year total effective dose equivalent from all exposure pathways, excluding the dose from radon and its progeny in air.

- Dose to representative members of the public via the air pathway shall not exceed $10 \mathrm{mrem}(0.10 \mathrm{mSv})$ in a year total effective dose equivalent, excluding the dose from radon and its progeny.

- Release of radon shall be less than an average flux of $20 \mathrm{pCi} / \mathrm{m}^{2} / \mathrm{s}\left(0.74 \mathrm{~Bq} / \mathrm{m}^{2} / \mathrm{s}\right)$ at the surface of the disposal facility. Alternatively, a limit of $0.5 \mathrm{pCi} / 1(0.0185 \mathrm{~Bq} / \mathrm{l})$ of air may be applied at the boundary of the facility.

In addition to the performance objectives, the Order requires, for purposes of establishing limits on the concentrations of radionuclides that may be disposed of near-surface, an assessment of impacts to water resources and to hypothetical persons assumed to inadvertently intrude for a temporary period into the low-level waste disposal facility.

The E-Area Low-Level Waste Facility, located on a 200 -acre site immediately north of the former low-level waste burial site (i.e., 643-7E), provides disposal capacity for solid, low-level, non-hazardous radioactive waste. This facility is planned to contain the following disposal units:

- two large concrete vaults for low-activity waste

- two large concrete vaults for intermediate-level non-tritium and tritium waste

- ten unlined trenches for disposal of soil and rubble with very low activity

- ten unlined trenches for disposal of intimately-mixed cement-stabilized waste

- ten unlined trenches for disposal of cement-stabilized encapsulated waste, and

- one gravel pad for disposal of up to 100 Naval Reactor Component waste containers.

This SA addresses disposal in the IL Vaults of a special category of wastes. These wastes contain high concentrations of I-129 and have measured, waste-specific desorption $\mathrm{K}_{d} \mathrm{~s}$. $\mathrm{K}_{d} \mathrm{~s}$ represent the partitioning of contaminants between the solid waste particles and the liquid that can transport the contaminant. This SA analyzes the transport of radionuclides from the waste to the publicly accessible environment. 
An important factor in estimating the transport of radionuclides to the environment at $\mathrm{E}$ Area is the long-term performance of the engineered features of the $\mathbb{L}$ Vaults. Therefore, degradation of these features, including moisture barriers and concrete waste forms, is addressed in this SA.

To evaluate the transport of I-129 from materials with measured, waste-specific I-129 $\mathrm{K}_{d} \mathrm{~s}$, sitespecific conceptual models were developed to consider:

- exposure pathways and scenarios of potential importance

- potential releases from the facility to the environment

- effects of degradation of engineered features, and

- transport in the environment to a designated point of compliance.

For evaluation of doses to off-site members of the public and impacts on water resources, the point of compliance is the point of highest concentration in groundwater or air more than $100 \mathrm{~m}$ from the disposed waste. For evaluation of doses to inadvertent intruders, the point of compliance is located at the point of highest concentration of radionuclides after a 100 -year institutional control period following closure of the facility.

This SA was used to determine the allowable I-129 inventories in the IL Vaults for materials with measured, waste-specific $\mathrm{K}_{d} \mathrm{~S}$. Allowable I-129 inventory limits were calculated by comparing estimated groundwater concentrations with the Maximum Contaminant Level (MCL, see Section 4.2.2) and by comparing off-site and intruder doses with DOE Order limits on doses. Calculated inventory limits were also compared with the 10 -year projected inventories for this type of waste.

The calculated inventory limit for activated carbon vessels of 7.14E-2 Ci (Section 5.1) is less than the 7.30E-2 $\mathrm{Ci}$ sum (Appendix A) of the existing and projected inventory for the existing $\Pi$ Vault. Thus, not all the projected I-129 inventory can be disposed in the existing ILV. This evaluation is based on the assumption that the entire $\mathrm{IL}$ Vault is filled with the waste being analyzed. Because the $\mathbb{L}$ Vault will contain other wastes as well, appropriate adjustments (i.e., use of sum-of-fractions) are required when calculating the contribution from each waste to the total allowable doses. 
SECTION 2

INTRODUCTION 
THIS PAGE INTENTIONALLY LEFT BLANK 


\section{INTRODUCTION}

This revision was prepared to address comments from DOE-SR that arose following publication of revision 0. This Special Analysis (SA) addresses disposal of wastes with high concentrations of I129 in the Intermediate-Level (IL) Vaults at the operating, low-level radioactive waste disposal facility (the E-Area Low-Level Waste Facility or LLWF) on the Savannah River Site (SRS). This SA provides limits for disposal in the IL Vaults of high-concentration I-129 wastes, including activated carbon beds from the Effluent Treatment Facility (ETF), based on their measured, wastespecific $K_{d} s$.

\subsection{Approach}

This SA was developed using the U.S. Department of Energy's (DOE) Order 435.1, Radioactive Waste Management, supplemented where needed, by the interim guidance for performance assessment (PA) (DOE 1996). The interim guidance that clarifies performance objectives in DOE Order 5820.2A, was used because similar guidance for the new DOE Order is not yet available.

Several steps were taken to streamline this document while completely addressing all requirements. First, screening methodologies were applied where appropriate. Detailed evaluation of exposure scenarios in Section 6 was limited to those that provided the maximum exposure to individuals. Second, only general supporting information was provided, e.g. meteorological data and environmental information, and additional details were referenced. Third, the revised performance assessment for the LLWF (PA revision, WSRC 2000) was referenced where the information or analysis was very similar.

The level of technical detail presented in the report, together with the Appendices, is sufficient to allow a reviewer to reproduce the results of the SA calculations. Where appropriate, intermediate results are provided. For example, the flux of each radionuclide to the water table, which is an intermediate result in the calculation of groundwater concentrations at the point of compliance, is presented in tables and plots. The Appendices include detailed supporting information.

\subsection{General Facility Description}

The E-Area LLWF is the site selected to store and dispose of all low-level radioactive waste generated during at least the next 20 years of SRS operations. The E-Area LLWF site is located on a 200-acre site immediately north of the former LLW burial site. Only 100 acres of the E-Area LLWF have been developed at this time (Fig. 2.2-1); the additional 100 acres will allow for expansion of LLW disposal capacity as needed. The nearest SRS boundary to the E-Area LLWF is about $11 \mathrm{~km}$ to the west. The E-Area LLWF is in a relatively level highland region of SRS at about $90 \mathrm{~m}(300 \mathrm{ft})$ above $\mathrm{msl}$.

The E-Area LLWF is designed to provide containment to reduce radionuclide migration from disposed LLW forms. Low-level waste will be disposed in trenches, concrete vaults, and on waste pads. The concrete vaults include Low-Activity Waste (LAW) Vaults and Intermediate-Level (IL) Vaults. Trench disposal includes rubble and miscellaneous wastes, intimately mixed cementstabilized waste forms (e.g., ashcrete and blowcrete from the Consolidated Incinerator Facility), and cement-stabilized encapsulated waste (CSEW). The waste pads hold naval reactor components. As current disposal units near capacity, additional disposal units will be constructed if needed. 


\subsubsection{High-Concentration I-129 Waste Disposal in Intermediate-Level Vaults}

\subsubsection{Description and Location}

IL Vault locations within the E-Area LLWF are shown in Fig. 2.2-1. Each IL Vault is subdivided into an Intermediate-Level Non-Tritium (ILNT) Vault and an Intermediate-Level Tritium (ILT) Vault. The ILT Vault will be used for disposal and storage of tritium-bearing waste, packed in 10gallon drums, or spent tritium extraction crucibles from which almost all the tritium has been removed, and tritium job control waste (JCW).

The ILT Vault and the ILNT Vault are similar in design. The ILT Vault is structurally identical to the ILNT Vault, except for length and depth. The ILT Vault consists of two cells or subdivided sections within the vault structure and provides approximately $1.6 \times 10^{3} \mathrm{~m}^{3}$ (56,000 cubic feet) of waste disposal capacity (Fig. 2.2-2). As originally conceived, one cell in the ILT Vault is fitted with a silo system to permit the disposal of tritium crucibles. The ILNT Vault consists of seven cells within the vault structure and provides approximately $5.7 \times 10^{3} \mathrm{~m}^{3}$ (approximately 200,000 cubic feet) of waste disposal capacity (Fig. 2.2-2). The base of the IL Vault is at an average elevation of $78 \mathrm{~m}(260 \mathrm{ft})$ above msl. Both the ILT Vault and the ILNT Vault use the same crane for waste container handling, they are immediately adjacent and are closed as a single unit.

\subsubsection{Major Design Philosophy}

Specific design measures were applied to the IL Vault to enhance safe operation, as described below:

1) Water Removal Provisions - The floor of each cell slopes to a drain that runs to a sump in the base slab. Any water accumulating in the sump can be monitored and removed through a $0.15-\mathrm{m}$ diameter riser pipe at the top of the wall. Any water that collects under the vault will flow to dry wells between the ILNT Vault and the ILT Vault. Access to the dry well is through a manhole at grade level.

Each cell has a removable metal rain cover consisting of a steel truss with a metal deck. The roof of the rain cover slopes slightly away from the center to allow water drainage. A crane is used to place the rain cover over the cell when the cell is not operating.

All concrete joints include a waterstop seal that is continuous around all corners and intersections. All exterior concrete surfaces exposed to soil are coated with tar-based waterproofing.

2) Radiation Shielding - Each cell can be covered with reinforced concrete slabs, known as shielding tees, to reduce the radiation level at the edge of the vault. The profile of these slabs is in the shape of the letter " $T$ " so that they can be interlocked to provide 0.5 $m$ of shielding. 


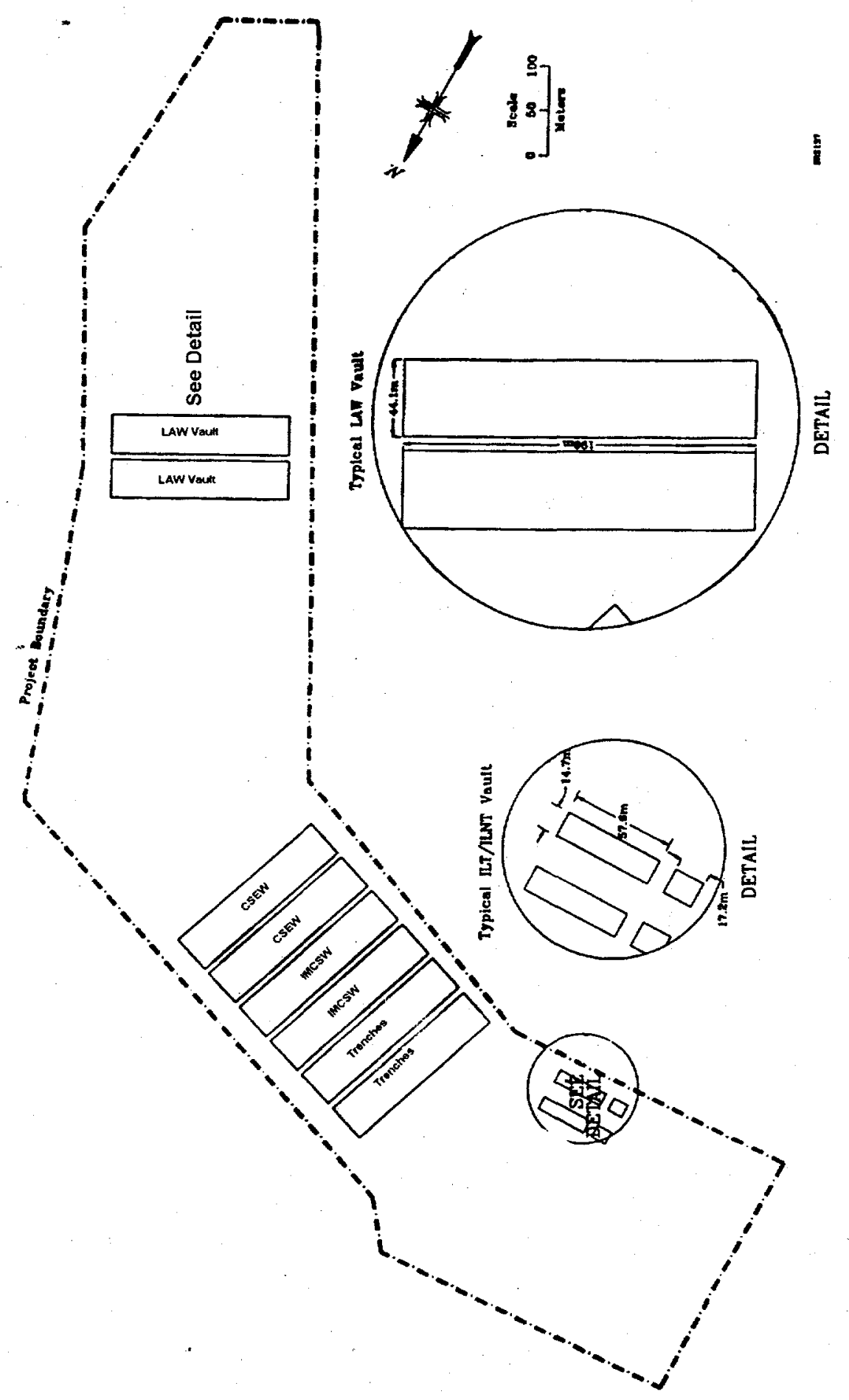

Figure 2.2-1 Projected Layout of the E-Area Low-Level Waste Facility 

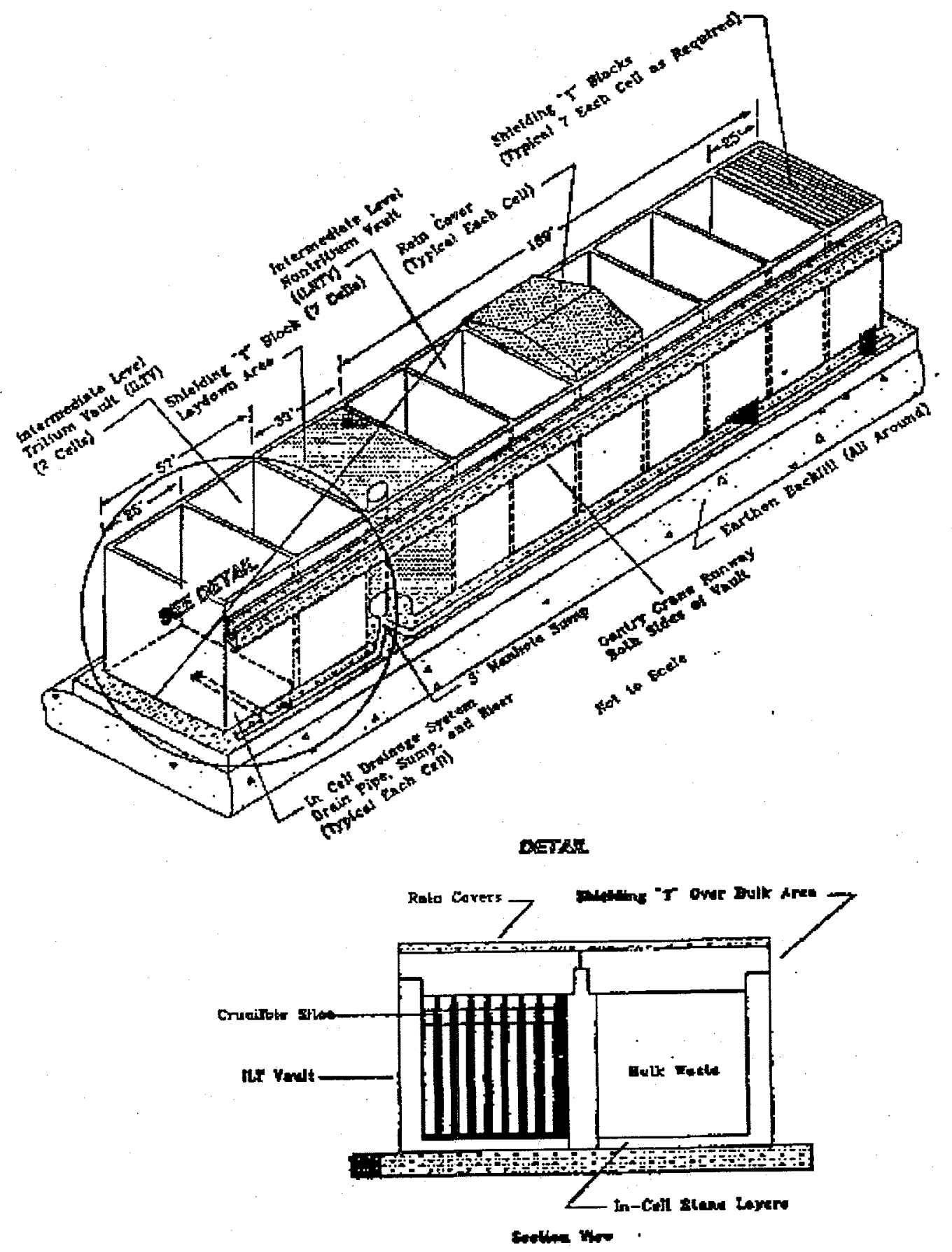

Figure 2.2-2. Arrangement of the Intermediate Level Non-Tritium and Intermediate Level Tritium Vaults 
The IL-Vault is classified as a Hazard Category 3 Facility (WSRC 1996a). However, the vaults were designed to meet the requirements of a Maximum Resistance (High Hazard) structure during the interim and final closure phases. The IL Vault satisfies the criteria for classification as a Standard Resistance (General Use) Structure.

As documented in the Structural Design Criteria (S2889-306-25-0) the IL Vault was designed and constructed to be a maximum resistance structure after closure. Site Specification 7096 requires that a maximum resistance structure be designed to withstand a $0.2 \mathrm{~g}$ earthquake event.

Each IL Vault has three distinct phases of operation and closure as follows:

1) Operating Phase - This phase involves waste emplacement. As each layer of waste containers is completed, grout is poured around and over the containers to form a new working surface for emplacement of the next layer.

2) Interim Closure Phase - After the final layer of waste containers is placed into the cell, a final layer of grout is placed in the cell and is leveled at the wall ledges that support the shielding slabs. A permanent roof slab of reinforced concrete is placed over the nine IL Vault cells. The roof slab is covered with fiberboard and a layer of waterproof membrane roofing.

3) Final Closure Phase - This phase will be performed after all vaults are interim-closed. Final closure consists of placing an earthen cover with an engineered clay cap over the entire E-Area LLWF.

\subsubsection{Facility Features}

The ILNT Vault is a below-grade, reinforced concrete structure approximately 58 meters ( 189 feet) long, 15 meters ( 48 feet) wide, and 9 meters ( 29 feet) deep with a seven-cell configuration (see Fig. 2.2-2). Exterior walls are 0.76 meters (2-1/2 feet) thick; and interior walls forming the cells are 0.46 meter $(1-1 / 2$ feet $)$ thick. Walls are structurally mated to a base slab that is approximately 0.76 meter (2-1/2) thick and extends past the outside of the exterior walls approximately 0.6 meter (2 feet). The base slab is supported on two layers of crushed stone placed on a compacted subgrade. Concrete construction joints are located at defined control joints, with no horizontal joints in any vertical wall.

The ILT Vault consists of two cells with a combined length of approximately $17 \mathrm{~m}(57 \mathrm{ft})$. One cell

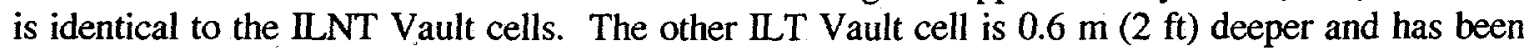
fitted with a silo storage system designed to house tritium crucibles (see Fig. 2.2-2). This cell is equipped with 142 silos, for tritium crucibles and tritium reservoirs. The crucibles are contained in overpacks. After a crucible has been placed in a silo, a $1-\mathrm{m}$ thick shielding plug is installed to reduce radiation exposure from the disposed crucible.

One IL Vault has been constructed, consisting of one ILNT vault and one ILT vault. It is assumed that future IL vault construction will be identical to the existing IL Vault - a combined single-vault configuration of nine cells housing both ILT and ILNT waste. 


\subsubsection{Waste Characteristics}

ETF and ER operations at SRS produce materials with relatively high concentrations of I-129. Because these materials concentrate I-129 from water, they are likely to retain the I-129 longer than other materials and to release it more slowly. The I-129 release rate from each material is calculated from the desorption solid-water partition coefficient $\left(\mathrm{K}_{\mathrm{d}}\right)$, where that coefficient represents the partitioning of contaminants between the solid waste particles and contacting liquid.

Desorption $\mathrm{K}_{d} \mathrm{~s}$ for these materials were measured in the laboratory and input to numerical models. Measured $K_{d} s$ higher than the literature-based value of $30 \mathrm{ml} / \mathrm{g}$ indicate slower release rates that translate into lower groundwater concentrations and lower doses to the public.

The ETF materials that contain high concentrations of $\mathrm{I}-129$ are GT-73 resin and Activated Carbon Vessels. The ER materials are sludge/filtercake, Dowex $21 \mathrm{~K}$ resin, and zeolite. Current plans are to dispose of only the Activated Carbon Vessels in the IL Vaults. Four Activated Carbon Vessels have already been placed in the existing IL Vault and grouted in place. The Activated Carbon Vessels are not radioactive enough to be classified as Intermediate Level waste. However, because of their configuration (i.e., size and weight) they cannot be emplaced in the LAW vault with existing equipment.

\subsubsection{Disposal Concept Considerations and Movement of Waste Through the Facility}

During the Operating Phase of the IL Vault, IL solid wastes are divided into tritium and non-tritium bearing fractions, and are disposed of separately in the ILT Vault and ILNT Vault, respectively. When a vault is being filled with waste, a crane removes the rain cover from the designated cell and any T-blocks that are installed over the designated cell. The crane transfers waste from the waste transport vehicle into the cell.

Waste containers placed in an $\mathbb{L}$ vault cell are periodically encapsulated in grout. Successive grout layers are cured before installing additional waste containers. After waste placement and grouting operations (as needed) are completed, T-blocks are reinstalled and rain covers are replaced.

The Interim Closure Phase commences after the final waste is placed in the IL Vault. A final layer of grout will be placed in each cell and leveled at the wall ledges that support the T-blocks. A permanent roof slab of reinforced concrete will be installed that completely covers the vault cells.

The Final Closure Phase completes the closure by placing an earthen cover with an engineered clay cap over the entire vault area.

Operation of the ILT Vault is similar to that of the ILNT Vault. The ILT Vault receives tritiumbearing waste, packed in either crucibles or 10-gallon containers, and tritium JCW. A permanent roof slab is installed at the start of interim closure.

The crucible-silo system is designed to receive overpacked tritium waste containers. Each crucible

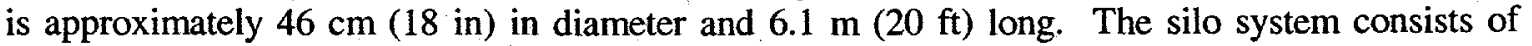
approximately $14250-\mathrm{cm}$ - (20-in-) diameter cylinders, uniformly placed and aligned to form a vertical grid. Each silo is provided with a separate concrete shielding plug. The ILT Vault cell 
operation is the same as that described for the ILNT Vault except that T-blocks are not required for ILT Vault cells containing the silo system, because the shielding plugs provide radiation shielding.

\subsubsection{Waste Acceptance and Certification}

All LLW is subject to the Waste Acceptance Criteria (WAC) of the 1S Procedure Manual (WSRC 1999b). The 1S Manual procedure, WAC 2.02, Low Level Waste Characterization Requirements, provides requirements associated with the development of suitable methods for characterization of waste packages. This procedure establishes the basis to ensure that all LLW packages presented to Solid Waste for treatment, storage, or disposal have been characterized by the generator to reasonably represent the physical, chemical, and radiological contents of the waste package with sufficient accuracy to permit proper segregation, treatment, storage, and disposal.

According to procedure WAC 2.02 , generators must periodically validate the radionuclide content and distribution in their waste streams after their initial certification. The purpose of periodic validation is to demonstrate that the waste stream distribution of the important radionuclides (i.e., those constrained by the WAC) has not changed significantly. The radionuclide content and distribution of all routinely generated SRS waste streams shall be reviewed and validated at least every two years.

The SRS certification procedure requires the generator to characterize the waste using laboratory

- analysis of representative samples. The procedure also requires that a facility sampling plan be used that ensures that samples are representative of the contaminated waste stream and are consistent and appropriate for each waste stream. After sample analysis results are screened, the remaining data shall be evaluated to consider:

- radionuclides identified in the data set compared to historic data sets, and reported values compared to historic sample data for the same waste stream,

- comparisons between in-house analysis results (if available) and independent laboratory results,

- scaling factor ranges relative to similar waste streams and historic data, and

- consistency of specific radionuclide results with gross analysis results.

The procedure indicates that characterization by means of sampling and analysis is the preferred method where it can be used. However, some waste streams cannot be adequately characterized through use of sampling and analysis techniques; therefore, process knowledge is appropriate and necessary.

Process knowledge includes the physical, chemical, and radiological properties of the materials involved in the process that generates the waste, the effect of all aspects of the process on the materials, associated process stream and product specifications, and administrative controls. Sources of process knowledge include historical operating and inventory records, analysis results, direct assay results, technical reports, documents and drawings specifying process areas and equipment, process equipment manuals, process stream or product specifications, documented mass balance information, and procedures. A radioisotopic distribution for a waste stream determined by process knowledge shall be validated using sampling and analysis of representative waste stream samples. 
Materials of the same type are assumed to have the same I-129 desorption $K_{d}$, e.g., all activated carbon from Activated Carbon Vessels is assumed equal. However, the $K_{d}$ has been shown to decrease as the concentration increases. If the I-129 concentration for any vessel is significantly higher than for the material that was measured, then further testing is needed or adjustments in disposal quantities are required.

\subsubsection{Land Use Patterns}

As described in Section 3.1.1.4, the use of land adjacent to the SRS is primarily rural.

\subsection{Schedules}

\subsubsection{Operation/Waste Receipt}

At this time, one IL Vault has been constructed. The next $\mathbb{L}$ Vault will be constructed when needed based on future site activities.

\subsubsection{Closure/Post-Closure}

The entire E-Area LLWF will be closed after it serves its useful life that is expected to last for at least 20 more years.

\subsection{Related Documents}

Section 2.4 of the PA revision (WSRC 2000) contains a list of related documents. The PA revision is another related document for this SA.

\subsubsection{Revised Performance Assessment for the E-Area LLWF}

The performance of a number of waste disposal units was assessed in the PA revision (WSRC 2000 ), including the ILV. That report, however, did not assess the performance of waste packages with high concentrations of specific radionuclides. Thus, this SA is an extension of the PA revision.

\subsection{Performance Criteria}

The information in this section is identical to that in Section 2.5 of the PA revision (WSRC 2000). The exception is that the agriculture inadvertent scenario in this report starts at 20,000 years, because waste excavation for a basement is not credible until then.

\subsection{Summary of Key Assessment Assumptions}

For protection of the public and assessment of impacts on water resources, exposure pathways involving direct ingestion of groundwater are the pathways of dominant concern for this SA (see Section 4). For protection of intruders, the agricultural scenario dominates. It yields doses that are about a factor of 10 greater than the post-drilling scenario and about a factor of 30 greater than the residential scenario (Tables B.3-13, B.3-14, and B-3.15). 
Assumptions of greatest importance to the projection of groundwater concentrations are those that affect the projection of release from the waste forms and subsequent transport to the point of compliance. Release from the waste forms is a strong function of the amount of water infiltrating to the disposal unit, the manner in which radionuclides are bound to waste, physical/chemical sorption properties of individual radionuclides, solubility of radionuclides, and the presence of engineered barriers to water flow.

The amount of infiltrating water and hydraulic properties of the soil matrix are important to the estimation of transport to the water table. However, for failed concrete, over long time periods when steady-state conditions are approached, hydraulic properties become less important, because the flow rate becomes controlled by the rate at which water infiltrates to the waste zone. Ultimately, groundwater concentrations are a function of the rate at which radionuclides reach the water table (affected by the parameters listed above) and of the parameters affecting transport through the aquifer.

Simulation of important release and transport processes requires a number of generally simplifying assumptions. Major assumptions that affect the predicted groundwater concentrations include:

1) moisture barriers (caps) are assumed to fail as soon as vaults fail, at 1,050 years

2) sorption is assumed to be adequately represented by non-site-specific sorption coefficients $\left(K_{d} s\right)$ for many radionuclides and materials, although waste-specific sorption coefficients are required for the high-concentration I-129 wastes

3) I-129 is assumed to exist as surface contamination available for transport

4) the volume of cells in the simulation domain used for the groundwater transport simulations is assumed to be adequately small to avoid introducing unrealistic dilution of the radionuclides after reaching the water table, and

5) the volume of cells is small enough such that numerical dispersion does not introduce unrealistic dilution of the radionuclides in the simulations. Numerical dispersion occurs when a grid element in a numerical model is larger than the distance a molecule may travel by advection in one time step of simulation.

Assumptions of greatest importance to the estimation of dose resulting from release of volatile radionuclides to air have to do with the rate at which volatile radionuclides are released to the atmosphere and the time at which the releases occur.

For estimation of dose to inadvertent intruders, exposure scenario definitions (assumptions) are perhaps most critical to the SA. Probably the most important assumptions are: 1) the inadvertent intruder has no knowledge of prior waste activities at the site; 2) the intruder will build a home or drill a well at the location of disposal units, rather than in uncontaminated areas; 3 ) the intruder. excavates or drills at the earliest time possible relative to degradation estimates for the various materials; and 4) exhumed waste is mixed with uncontaminated soil, and a garden is planted in the resulting mix. These important assumptions tend to maximize calculated dose to the intruder and thus provide a pessimistic evaluation of performance of the facility with respect to impacts on intruders. 
THIS PAGE INTENTIONALLY LEFT BLANK

Rev. 1

July 31,2000 
SECTION 3

DISPOSAL FACILITY CHARACTERISTICS

Rev. 1

July 31,2000 
THIS PAGE INTENTIONALLY LEFT BLANK

Rev. 1

July 31,2000 


\section{DISPOSAL FACILITY CHARACTERISTICS}

\subsection{Site Characteristics}

Site characteristics for high-concentration I-129 waste in the IL Vaults are identical to those for cement-stabilized encapsulated waste trenches at the E-Area LLWF. Thus, Section 3.1 in WSRC 2000 provides the needed site characteristics information for this SA. The only difference is that the seismic events could crack the vaults, rather than the encapsulating material.

\subsection{Principal Facility Design Features}

A key objective for closure of a waste disposal site is to limit moisture flux through the waste, thus minimizing contamination of the underlying groundwater. Because the E-Area LLWF is designed as a controlled release facility, proper closure to meet the objective of limiting moisture flux through the waste will be an integral part of long-term acceptability of the disposal site. Backfilling and final closure of the E-Area LLWF will be delayed for several years, hence a detailed closure design has not been fully developed. A closure concept must be described and tested in models that simulate its performance characteristics.

\subsubsection{Intermediate-Level Vault Closure Concept}

\subsubsection{Water Infiltration and Disposal Unit Cover Integrity}

Each IL Vault will be closed in stages. Individual cells will be closed as they are filled then the entire vault area will be closed. Final closure consists of placing an earthen cover with an engineered clay cap over the entire vault area. This closure activity will be combined with construction of a drainage system and revegetation using bamboo.

The closure concept developed for this SA is illustrated in Fig. 3.2-1. Closure operations begin when an individual cell is filled with waste. The concrete roof of the vault will be installed by tying its reinforcing steel into the reinforcing steel of the vault itself, forming a unified structure. Backfill will be placed around and over the disposal units after all vaults and trenches have been filled, although backfilling may begin slightly earlier.

At least $0.9 \mathrm{~m}$ of backfill will be placed over the vaults. This layer will serve to establish slopes for the overlying layers so that infiltrating water will tend to flow down the slope and away from the vaults, limiting the amount of infiltration into the vaults themselves. Above this layer of backfill, a laterally extensive moisture barrier will be installed. This moisture barrier will consist of $0.76 \mathrm{~m}$ of clay and an overlying layer of $0.3 \mathrm{~m}$ of gravel. A geotextile fabric will be placed over the gravel layer, and a second backfill layer, approximately $0.76-\mathrm{m}$ thick, will be placed over the moisture barrier. Finally, a $0.15-\mathrm{m}$ layer of topsoil will be placed over the top backfill layer. This sequence of layers provides a minimum of $2.9 \mathrm{~m}$ of cover for each vault.

Final closure of the E-Area LLWF will be accomplished by constructing a drainage system and revegetating the site. The drainage system will consist of a system of rip-rap lined ditches that intercept the gravel layer of the moisture barrier. These ditches will divert surface runoff and water intercepted by the moisture barrier away from the disposal site. The drainage ditches will be constructed between rows of vaults and around the perimeter of the E-Area LLWF. 

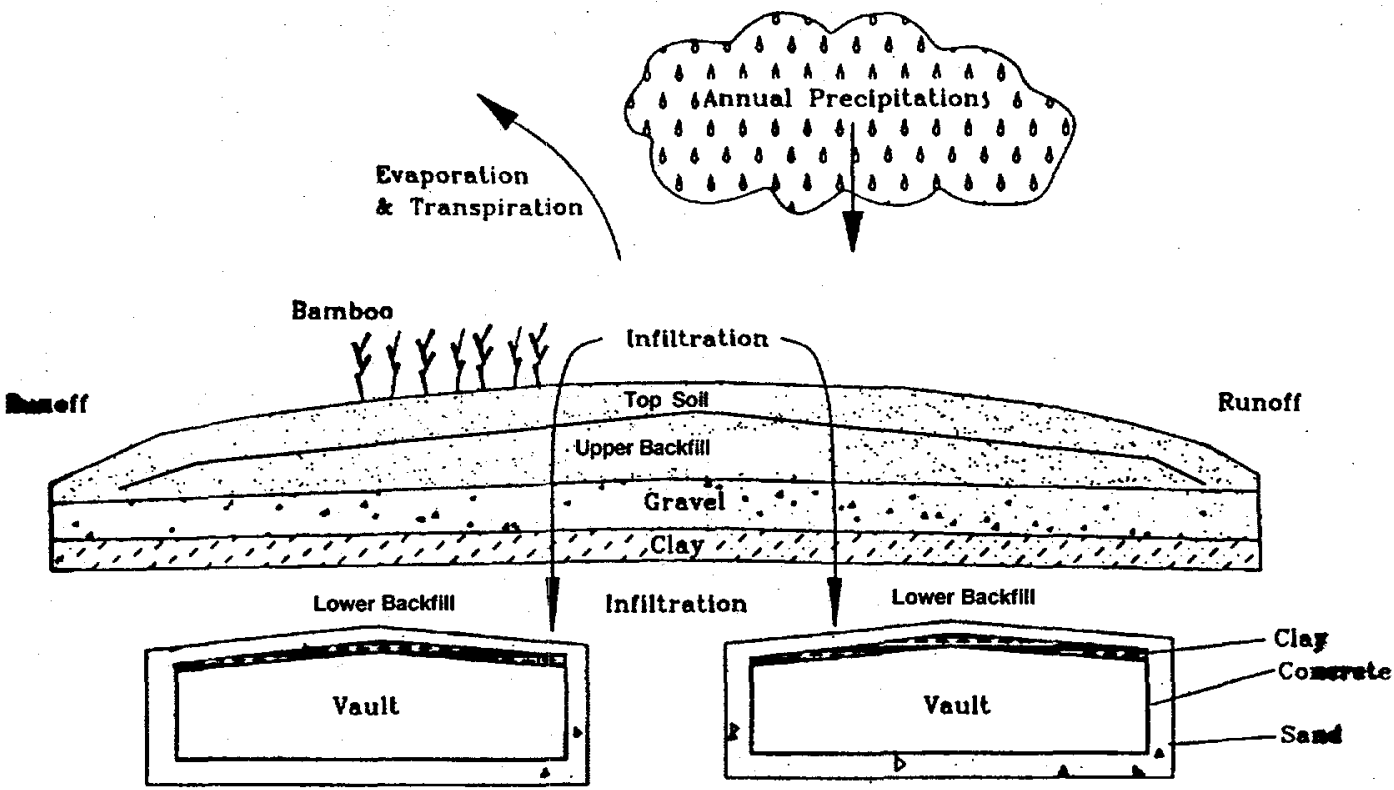

$\nabla$ Water Table

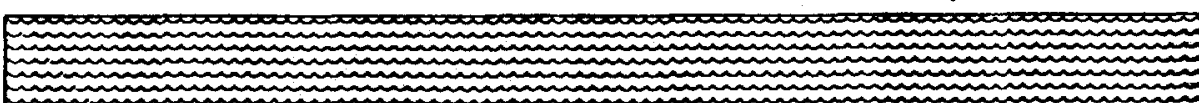

Figure 3.2-1. Vault closure concept (intact cover system) 
The topsoil will be revegetated with bamboo. A study by the USDA Soil Conservation Service (Salvo and Cook 1993) has shown that two species of bamboo (Phyllostachys bissetii and Phyllostachys rubromarginata) will quickly establish a dense ground cover that prevents the growth of pine trees, the most deeply-rooted naturally-occurring plant type at SRS. Bamboo is a shallowrooted climax species that evapotranspirates year-round in the SRS climate, thus, removing a large amount of moisture from the soil and decreasing infiltration into the underlying disposal system.

Performance requirements for the closure concept are expressed in terms of hydraulic properties for the various soil layers (Thompson 1991). These nominal properties are listed in Table 3.2-1. The topsoil and upper backfill layer serve to store and distribute infiltrating water. These layers intercept incoming water and redirect a significant portion in the horizontal direction to drainage ditches installed at the E-Area LLWF. Computer simulations of flow through the cover show that the gravel drainage layer will carry away a major portion of the water that would normally infiltrate at the E-Area LLWF $(40 \mathrm{~cm} / \mathrm{yr})$.

Table 3.2-1 Values for hydraulic properties of vault closure design

\begin{tabular}{cc}
\hline Layer Description & Hydraulic Conductivity $(\mathrm{cm} / \mathrm{s})$ \\
\hline Clay & $1.0 \times 10^{-7}$ \\
Gravel & 0.5 \\
Backfill & $1.0 \times 10^{-5}$ \\
\hline
\end{tabular}

\subsubsection{Structural Stability and Inadvertent Intruder Barrier}

The IL Vaults include features that promote structural stability as follows:

- The vaults are below-grade reinforced concrete structures. All walls are structurally mated to 2.5 -foot thick concrete base slabs that extend approximately 2 feet beyond the outside of the exterior walls. The vaults are designed to withstand loads imposed by Design Basis Accidents and therefore, assure continued structural stability.

- Waste is placed in engineered metal containers before being brought to the vault. The containers are stacked in layers. After a layer of waste containers is placed in a cell, grout will be poured to encapsulate the containers and form a surface for emplacement of the next layer of containers.

- After being filled with waste and layers of grout, the vault will be covered with a top layer of grout. A thick (thickness varies from 2-feet - 3inches to 3-feet - 2 inches) reinforced-concrete roof slab will completely cover all nine cells of the IL Vault. The roof slab will extend over and around the cell-wall stubs and will be covered with a bonded-in-place layer of fiberboard insulation and a layer of waterproof membrane roofing. Structural stability of the $\mathbb{L}$ vault roof is expected for about 1,050 years (Appendix D of WSRC 2000). The roof and grout layer provide a barrier both to water infiltration and to intrusion before that time. 
Confinement features for the $I L$ tritium portion of the $\mathbb{L}$ vault are the same as the ILNT portion. One ILT cell is identical to ILNT cells. The other ILT cell contains silos for disposing of tritium crucibles in silos. The silo system consists of vertical cylinders that are grouted in place, thus providing stabilization and shielding.

\subsection{Waste Characteristics}

Low-level radioactive solid waste may be segregated by the Waste Generator into eight categories. The disposition of waste containers in the E-Area LLWF is based on this segregation. The waste categories are as follows:

1) Low-activity waste

2) Intermediate-level tritium waste

3) Intermediate-level non-tritium waste

5) E-Area trench waste

6) Naval Reactor Components

7) Intimately-mixed cement-stabilized waste

8) Cement-stabilized encapsulated waste

This SA addresses a sub-category of the Intermediate-level not-tritium waste, namely waste with a high I-129 concentration.

\subsubsection{Intermediate-Level Vaults}

\subsubsection{Waste Type/ Chemical and Physical Form}

The IL Vault will be used for disposal of $\mathrm{IL}$ waste. $\mathrm{IL}$ waste is defined at SRS as waste radiating greater than $200 \mathrm{mR} /$ hour at a distance of $5 \mathrm{~cm}$. Intermediate-level waste consists of job control waste (JCW), scrap hardware, contaminated soil and rubble, and wastes in non-standard containers. $\mathbb{L} \mathrm{JCW}$ is primarily highly contaminated lab coats, plastic suits, shoe covers, plastic sheeting, etc. JCW is typically combustible and is contaminated primarily with fission products. Scrap hardware waste consists of reactor hardware, reactor fuel and target fittings, jumpers, and used canyon and tank farm equipment contaminated with fission products and/or induced activity. Contaminated soil and rubble result from cleanup and decommissioning operations. Wastes in non-standard containers are those that normally could be disposed in the LAW vaults, but the size or shape of the container prevents that means of disposal.

All $\amalg$ waste will be packaged in engineered metal or concrete containers that have been approved by Solid Waste Management. The containers will be remotely placed into the vault in layers. $\mathbb{I}$ waste containers will be grouted in place to provide better waste isolation, reduce dose to operators, and improve stacking of additional containers.

\subsubsection{Radionuclide Inventory}

The 10-year projected inventory of high-concentration I-129 waste for the IL Vaults is provided in Appendix A. 


\subsubsection{3 - Waste Volume}

The IL vault provides approximately $5.7 \times 10^{3} \mathrm{~m}^{3}$ of waste capacity for ILNT waste and $1.6 \times 10^{3}$ $\mathrm{m}^{3}$ for ILT waste (Section 2:2.1.1). If disposal limits are not exceeded, waste volumes may approach that capacity for both IL vaults during the period of operation of these units.

\subsubsection{Packaging Criteria}

All LLW is subject to the packaging requirements of the 1S Manual. Most LLW will be received in standard $1.2 \times 1.2 \times 1.8 \mathrm{~m}\left(2.5 \mathrm{~m}^{3}\right)$ metal containers (B25 boxes). Some waste will also be received in standard $0.6 \times 1.2 \times 1.8 \mathrm{~m}\left(1.3 \mathrm{~m}^{3}\right)$ containers (B12 boxes) or 210-L (55-gallon) drums. The LLW may also be received in non-standard engineered concrete or metal containers. These containers shall be pre-approved by Solid Waste Management prior to their receipt at the E-Area LLWF.

Many different containers will be received at the E-Area LLWF. However, all containers are required by the Technical Safety Requirements (TSRs) to be engineered concrete or metal containers that have been approved by Solid Waste. Solid Waste verifies that the container can be safely handled, will not impair vault space utilization, and will satisfactorily contain the waste contents.

B25 and B12 carbon-steel boxes have been used in the past for waste disposal in the SWDF. The boxes are similar in construction, differ in size. The B25 is typically constructed of 14-gauge carbon steel $(1.9 \mathrm{~mm})$ but some B25s are constructed of 12-gauge carbon steel $(2.6 \mathrm{~mm})$ to allow use in the compactor. The B12 is typically constructed of 12-gauge carbon steel.

\subsubsection{Pre-Disposal Treatment Methods}

No pre-disposal treatment methods are currently planned for $\mathbb{L}$ waste.

\subsubsection{Waste Acceptance Restrictions}

Waste acceptance for disposal in the IL vaults must conform to criteria put forth in the SRS WAC (WSRC1999b). 
THIS PAGE INTENTIONALLY LEFT BLANK 
SECTION 4

ANALYSIS OF PERFORMANCE

Rev. 1

July 31,2000 
THIS PAGE INTENTIONALLY LEFT BLANK 


\section{ANALYSIS OF PERFORMANCE}

The methods used to analyze the long-term performance of the high-concentration I-129 waste in the IL Vaults are described in this chapter. Source term development is addressed in Section 4.1, where a discussion of potential mechanisms of contaminant release from the disposal units is provided. In that section, the screening process used to identify potentially significant radionuclides for different analyses is also described.

In Section 4.2, potentially significant exposure pathways and scenarios for off-site members of the public are described. Screening pathways and scenarios are also discussed in this section, as are receptor locations for subsequent analysis.

Finally, in Section 4.3, the conceptual models developed to analyze the fate and transport of I-129 released from the high-concentration I-129 wastes in the IL Vaults for the pathways identified in Section 4.2 are described. Computational methods used to evaluate the models are also discussed.

\subsection{Source Terms}

In this section, mechanisms and factors that affect the rate of potential release of radionuclides from the IL disposal units to the environment are discussed. Screening techniques used to focus analyses on significant processes are also described. After significant processes are identified, conceptual models for release from waste forms and disposal units are presented. These models address releases from initially intact disposal units and releases from units after degradation of engineered barriers has occurred. Simulation models and assumed values of model parameters are discussed. Calculated releases to the environment over time are provided.

\subsubsection{All-Pathways Analysis}

In an all-pathways analysis, the potential for air, groundwater (above or below the water table), surface water, and soil to carry radionuclides from $\mathrm{E}$ Area to off-site locations is considered. The source term analysis for a disposal facility considers how radionuclides might be directly released to these four media. The description of pathways and scenarios for the all-pathways analysis (Section 4.2.1) considers how radionuclides released to a medium may be transported within and between media to locations where human exposure may take place.

The $\mathrm{IL}$ disposal units are subsurface units, with overlying soil extending in excess of $2 \mathrm{~m}$ from the top of the units to the ground surface when closure is complete. Release to the subsurface soil surrounding the waste units by diffusion and advection is probable. Direct release of radionuclides from the disposal units to overlying surface soil, air, or nearby surface water is highly unlikely, except for release of volatile radiological components of waste (i.e., tritium, ${ }^{14} \mathrm{C}$, and radon). Erosion of cropland near the SRS is on the order of $0.08 \mathrm{~cm} / \mathrm{y}$ (from Section 3.1.4.1.6 in the PA revision, WSRC 2000, assuming a soil matrix density of $2650 \mathrm{~kg} / \mathrm{m}^{3}$ ). However, the presence of a final vegetative (i.e., bamboo) cover will lower the erosion potential in a manner similar to that of a successional forest, by a factor of about 400 to 500 (Section 3.1.4.1.6 in WSRC 2000). Thus, natural processes uncovering $I L$ Vaults during the first $1,000,000$ years after disposal is not expected, but credit is only taken for the first 10,000 years. The final vegetative cover will be a climax species that prevents the growth of deep-rooted pine trees native to the area. This deterrent and the vegetative cover's capability to limit other types of biointrusion (see Section 4.2.1) makes the significant movement of nonvolatile radionuclides 
upwards toward the soil surface unlikely. Therefore, the source term analysis focuses on the source of radionuclides released to the groundwater in the vadose, or unsaturated, zone. With this focus, development of the source term for both the all-pathways analysis and the water-resource impacts analysis will be identical and is described in Section 4.1 .3 below.

\subsubsection{Air Pathways Analysis}

The air pathway analysis addresses potential emission of volatile radionuclides from the E-Area LLWF, including the IL Vaults. Screening analyses (Cook and Wilhite 1998) show that only HTO (tritiated water vapor), HT and ${ }^{14} \mathrm{C}$ could produce doses of concern via the air pathway. Therefore, I-129 releases via the air pathway need not be considered further.

\subsubsection{Water Resource Impacts Analysis}

The source term analysis for impacts on water resources addresses the potential release of radionuclides from the IL Vaults to the vadose zone surrounding them. Release may occur when water contacts the waste and radionuclides are leached from the waste form or when radionuclides diffuse from the units. The source term analysis requires development of a conceptual model to represent mechanisms of release and factors affecting the rate of release.

\subsubsection{Conceptual Model of the Source Term}

The rate of release for any particular radionuclide to the subsurface is a function of:

- the quantity of that radionuclide initially disposed of (i.e., radionuclide inventory)

- the rate of water infiltration into disposal units

- integrity of barriers to resist water intrusion over time

- the composition of infiltrating water contacting waste, and

- the physical form, solubility, sorptive, and diffusive behavior of the radionuclide (i.e., their physical/chemical characteristics).

Each of these parameters is discussed below, as it relates to mechanisms of release and to the conceptual model used to simulate the releases. The two-dimensional vadose zone model discussed in Section 4.3.2.1 allows horizontal and vertical water infiltration into the vault and waste release from the vault.

\subsection{Radionuclide Inventory}

Projected inventories are provided in Appendix A.

Screening I-129 for water-resource impacts analysis was not attempted, because the disposed inventory in the $\mathbb{I}$ Vault exceeds the current WAC, so it is known to be a potential problem. Screening of the large projected inventory with respect to intruder doses was not performed either (see Section 6).

\subsection{Rate of Water Infiltration into Disposal Units}

Release of radionuclides from waste is triggered by contact with water that has seeped into the waste disposal units from the surrounding vadose zone. The rate of water infiltration into the disposal units is a function of the infiltration rate of rainwater into the subsurface and the efficiency of engineered barriers that serve to divert water away from the waste in the disposal 
units. Boxes or other containers used to facilitate placement of waste into disposal units are not considered reliable barriers to water infiltration.

The conceptual model of water infiltration considers the types of engineered barriers (e.g., moisture barriers, vaults, grouted waste forms) associated with the disposal units (Section 3.2). Infiltration through these barriers is simulated using the numerical code PORFLOW (Appendix B of WSRC 2000), which provides estimates of rates of water movement through the subsurface soil, engineered barriers, and waste forms to the water table. More in-depth descriptions of the simulation domains used and assumptions made to estimate this transport are provided in Section 4.3.3 of the PA revision (WSRC 2000).

\subsection{Integrity of Barriers to Resist Water Intrusion}

Degradation of engineered barriers is expected to occur over time, thus increasing the influx of water to the wastes. Degradation will affect infiltration barriers, which are constructed for all units, and concrete vaults, containers, and cementitious or solid metal waste forms, which are present in some units.

Infiltration barrier degradation. Degradation of the infiltration barrier (clay/gravel drain system) is expected to occur by a number of natural processes. Potential processes include erosion, intrusion by plants and animals, and external events such as settling or slumping or a seismic event. These processes will reduce the effectiveness of the cover in limiting the vertical moisture flux.

As presently conceived in the closure concept (Section 3.2), shallow-rooted bamboo will be planted on the disposal site and a system of drainage ditches will be constructed to handle surface runoff and diverted infiltration. During the period of active institutional control it is assumed that periodic site inspection would reveal any degradation of the overlying cover and drainage system and corrective actions would be taken. Cover degradation during the institutional control period is therefore likely to be minimal. Sheet erosion will occur, but the final vegetative cover would minimize the effects of this disturbance.

Return of the SRS land to unrestricted use at the end of the active institutional control period may result in a usage conversion to agricultural practices, consistent with past and current land use in the SRS vicinity. Row crop farming, which is consistent with historical practices in the vicinity, would increase the erosive effects of precipitation. Soil erosion rates for cropland near the SRS are on the order of $2 \mathrm{~kg} / \mathrm{m}^{2} / \mathrm{yr}$ (Section 3.1.4.1.6). Erosion is reduced several hundred fold if a dense vegetative cover is present (Section 3.1.4.1.6). This suggests that there will be little erosion as long as the final vegetative layer has not been cleared. However, if the final vegetative layer is cleared, the cover may be eroded down to the gravel layer in as little as 650 years. Erosion of the gravel layer is difficult to predict.

In this analysis, roof failure rather than erosion was considered to be the driving factor for degradation of the infiltration barrier. The cover was assumed to remain fully functional until the roof of the vaults fails. At that time, the permeability of the gravel and clay materials are assumed to be the same as that of the top soil and backfill soil, respectively.

Vault degradation. The concrete vaults are expected to degrade slowly through a combination of physical, chemical, and mechanical processes (Walton et al. 1990). Physical and mechanical degradation processes that produce cracking are of primary concern, because of the concomitant increase in permeability. Shrinkage cracks occur as a result of the temperature cycling during 
curing of concrete structures, and thus are present before the facility closure cover is constructed. This allows for filling the outer portion of the cracks in the vault walls or roof with epoxy prior to closure. Cracking can occur after the vaults have been covered as a result of degradation of the epoxy used to fill shrinkage cracks, foundation settling, or rebar expansion due to corrosion. Eventually, structural failure (collapse) of the vault roofs may occur.

The principal chemical processes that disrupt the integrity of concrete structures are sulfate attack, carbonation, calcium hydroxide leaching, and rebar corrosion. The effects of these processes on vault degradation have been analyzed using a method described in Walton, et al. (1990). The analysis of chemical degradation effects and concomitant structural impacts are discussed in detail in Appendix D of the PA revision (WSRC 2000). The results of this analysis indicated that cracks completely penetrating the $\mathrm{IL}$ vault roofs are most likely to occur around 575 years for the $\mathbb{I L}$ vaults. Vault failure was defined as structural collapse of the vaults. This was estimated to occur at approximately 1,050 years for $\mathbb{L}$ vaults. The degradation scenarios assumed for these vaults utilize these estimates for times that degradation and failure of the vaults occur. For the IL vaults, in which voids are filled in with grout, the hydraulic characteristics of the waste compartment are assumed to mimic those of native soil after roof failure.

Subsidence is an issue that must be considered for all waste disposal units at E Area. For the $\mathbb{L}$ Vaults, all significant voids within the waste form are assumed to be filled with grout. Thus, only minimal subsidence is expected to occur.

\subsection{Composition of Infiltrating Water}

The composition of water infiltrating the disposal units will potentially affect the solubility or sorptive characteristics of radionuclides in the wastes. Water that has infiltrated vaults will have a composition that reflects the interaction of concrete pore water with vadose zone water. The presence of $\mathrm{CO}_{2}$ gas in the soil and calcite present as a weathering product in the cement will buffer the $\mathrm{pH}$ of the water to between 7 and 8. Corrosion products of metals that are present in the disposal units, arising either from waste containers or surface contaminated wastes, may also be present in the water contacting wastes.

\subsection{Physical/chemical characteristics.}

The physical and chemical form of I-129 in high-concentration I-129 wastes disposed in the IL Vaults will vary according to the form the radionuclide is in when disposed and conditions in the disposal unit that may cause a change in form over time. Considerable uncertainty exists regarding conditions in the units over time that may cause a change of form. Therefore, assumptions regarding chemical and physical form generally are based on limited available information derived from consideration of the probable water composition in the waste disposal units, discussed above. Conservative assumptions are generally made regarding physical and chemical forms that tend to overestimate the mobility of radionuclides from the disposal units and thus overestimate the concentrations in groundwater.

However, specific sorption characteristics were assigned to high-concentration I-129 wastes based on laboratory measurements. Those measurements were made under laboratory conditions that approximated vault conditions. The measured $\mathrm{I}-129 \mathrm{~K}_{d} \mathrm{~S}$ are valid only for the specific type of waste form that was tested in the laboratory and only for I-129 concentrations at or below the concentrations for the tested materials. For materials other than the actual waste form, the $\mathrm{K}_{d} \mathrm{~s}$ for I-129 were assigned based on other site-specific tests or on literature values. 
Radionuclides are assumed present as surface contamination that is leached according to laws governing solubility and sorption. Wastes are represented as porous media thus maximizing the surface area of the waste potentially exposed to infiltrating water.

Sorption coefficients $\left(\mathrm{K}_{d} s\right)$ used in the analyses of release from waste forms are listed in Table 4.1-3. Selection of $\mathrm{K}_{d} \mathrm{~s}$ was made according to the following rationale: waste-specific and sitespecific values of soil $\mathrm{K}_{\mathrm{d}} \mathrm{s}$ are considered most appropriate; when available, they were used. Next, the comprehensive listing of default values by Sheppard and Thibault (1990) was consulted for $K_{d} s$ in soil and clay. The sandy soil $K_{d}$ was selected for "soil" because this value tends to be lower than for other soil types and thus is conservative (i.e., may overestimate radionuclide

- mobility) with respect to water-resource impacts. For concrete, a listing of $K_{d} s$ by Bradbury and Sarott (1995) was consulted. For waste in which corrosion products are expected to affect sorption, $\mathrm{K}_{\mathrm{d}} \mathrm{s}$ were developed in Appendix $\mathrm{E}$ (Geochemical Interactions) of the PA revision (WSRC 2000).

Table 4.1-3 Elemental Sorption Coefficients $\left(K_{d} s\right)$ for I-129 in IL Vaults

\begin{tabular}{|c|c|c|c|c|c|c|c|c|c|}
\hline \multirow[b]{3}{*}{ Element } & \multicolumn{9}{|c|}{$\mathrm{K}_{\mathrm{d}}(\mathrm{mL} / \mathrm{g})$} \\
\hline & & Typical & & & Activated & & & Dowex & \\
\hline & Soil ${ }^{\mathrm{a}}$ & $\begin{array}{l}\text { Grouted } \\
\text { Waste }^{b}\end{array}$ & Gravel $^{\mathrm{a}}$ & Clay $^{c}$ & $\begin{array}{l}\text { Carbon } \\
\text { Vessels }^{\text {e,f }}\end{array}$ & $\begin{array}{l}\text { GT-73 } \\
\text { Resin }^{\text {e }}\end{array}$ & $\begin{array}{l}\text { Sludge/ } \\
\text { Filtercake }\end{array}$ & $\begin{array}{l}21 \mathrm{~K} \\
\text { Resin }^{\mathrm{e}}\end{array}$ & Zeolite \\
\hline I & $0.6^{\mathrm{d}}$ & 2 & $0.6^{\mathrm{d}}$ & 1 & 600 & 3100 & Unknown & 2800 & Unknown \\
\hline
\end{tabular}

a Values are for sand from Sheppard and Thibault (1990), unless otherwise noted.

b Values from Bradbury and Sarott (1995) for IL Vaults.

c Values are for clay from Sheppard and Thibault (1990), unless otherwise noted.

d Site-specific value from Hoeffner (1984).

e Waste-specific value from Kaplan, et al. (1999).

f Only waste form planned for disposal in IL Vaults.

Diffusion of radionuclides through porous media is a potentially important means of release from some E-Area waste disposal facilities, because intact engineered barriers limit convective transport. For a given porous material, it is reasonable to assume that apparent diffusion coefficients (molecular diffusion coefficients corrected for tortuosity of the porous medium) are similar for all radionuclides because molecular diffusivities in water do not vary significantly. Apparent diffusion coefficients will vary, however, between porous materials because of differences in tortuosity. Tortuosity cannot be measured directly, but apparent diffusion coefficients have been obtained empirically for conservative (nonsorbing, nonreactive, nondecaying) compounds. Apparent diffusion coefficients assumed for the various porous materials encountered are listed in Table 4.1-5. Calculation of diffusional release is part of the mass transport simulations described in Section 4.3 .2 below. 
Table 4.1-5 Diffusion Coefficients Assumed for Mass Transport Simulations

\begin{tabular}{lll}
\hline \multicolumn{1}{c}{ Material } & $\begin{array}{c}\text { Apparent } \\
\text { Diffusivity } \\
\left(\mathrm{cm}^{2} / \mathrm{s}\right)\end{array}$ & \multicolumn{1}{c}{ Source } \\
\hline $\begin{array}{l}\text { Top soil and native } \\
\text { soil }\end{array}$ & $5 \times 10^{-6}$ & Freeze and Cherry, 1979 \\
$\begin{array}{l}\text { Gravel } \\
\text { Clay }\end{array}$ & $1 \times 10^{-5}$ & $\begin{array}{l}\text { assumed equal to molecular diffusivity without } \\
\text { tortuosity correction } \\
\text { Assumed to be less than value for soil, due to } \\
\text { increased tortuosity of the more porous clay } \\
\text { assumed same as for top soil and native soil } \\
\text { Liam, et al. 1992 }\end{array}$ \\
$\begin{array}{l}\text { Concrete and } \\
\text { cementitious waste }\end{array}$ & $\begin{array}{l}1.5 \times 10^{-6} \\
1 \times 10^{-8}\end{array}$ & \begin{tabular}{l} 
Liam, \\
\hline
\end{tabular}
\end{tabular}

\subsubsection{Estimated Releases of Radionuclides}

Computational analysis of the release of radionuclides from the waste to the surrounding vadose, or unsaturated, zone environment of the disposal units is an integral part of the total analysis of transport from the waste to the point of compliance for water-resource impacts analysis. This total analysis is described in detail in Section 4.3.3. A separate accounting of quantity of radionuclides released from the waste forms before transport in the vadose zone is not readily available. However, the fractional release of radionuclides to the saturated zone (i.e., fraction of original inventory released as a function of time) is readily available. Tabulated results of these calculations are provided in Section 4.3.2.

\subsection{Exposure Pathways and Scenarios}

The source-term analysis in Section 4.1 provides estimates of release of radionuclides from the waste disposal units to the immediate environment. These releases are considered with respect to how radionuclides might be further dispersed and ultimately lead to exposures to off-site members of the public. To evaluate exposures in terms of stated performance objectives (Section 2.5) significant pathways and scenarios relevant to estimating exposures for the all-pathways analysis and the water-resource impacts analysis must be identified. Note that the air-pathway analysis was screened out in Section 4.1.2.

\subsubsection{All-Pathways Analysis}

To evaluate the potential sources of off-site contamination, numerous pathways to human exposure from buried LLW are considered. A diagram of pathways to human receptors from a subsurface source of radionuclides is shown in Fig. 4.2-1. Arrows represent pathways of radionuclide movement from the source, between media (compartments represented by boxes), and eventually to a human receptor. Solid arrows represent dominant pathways, while dotted arrows represent insignificant pathways. The pathways identified in this figure are for sources undisturbed by human intrusion. Pathways pertinent to intruder exposures are addressed separately in Section 6. 


\subsubsection{Descriptions of Pathways}

From the subsurface source, radionuclides can move directly into any of three media, represented by the first column of boxes in Fig. 4.2-1. Radionuclides may diffuse in the air-filled voids in the soil to the air, be moved to the surface (cover) soil by burrowing animals or deep tree roots, or be leached by infiltrating water and transported to underlying aquifers or isolated perched-water zones. The groundwater compartment represents aquifers and any isolated perched-water zones.

Volatile radionuclides from the air compartment may be transported in air and inhaled by a human receptor. These radionuclides may exchange (arrows in both directions) with the cover soil. These radionuclides may be deposited on the cover soil, and radionuclides from the cover soil may become airborne, completing the exchange process. Volatile radionuclides from the air compartment may exchange with terrestrial biota, such as crops and cattle. Volatile radionuclides may be deposited on crops or cattle, and they may become airborne again. Volatile radionuclides may be deposited on surface water and become airborne again.

Cover soil radionuclides can be directly ingested by humans, such as by a child consuming dirt or by eating vegetables that are incompletely washed. These radionuclides can be exchanged with terrestrial biota. Uptake by crops and cattle can occur or they can redeposit radionuclides on the cover soil. Exchange with surface water can occur from events such as runoff and flooding. Exchange with groundwater is also possible via leaching and irrigation.

Groundwater compartment radionuclides can be directly ingested by humans. These radionuclides can be exchanged with terrestrial biota. In this particular instance, irrigation of crops can be significant (see Section 4.2.1.2), but deep roots releasing radionuclides to the groundwater is not considered to be significant because of a thick ( 15 feet) cover and the bamboo. Radionuclides from the groundwater compartment may reach surface water at locations where there are seeps or streams. However, surface water does not contaminate groundwater, because the streams on the SRS are gaining streams and do not recharge groundwater.

The second column of compartments consists of Terrestrial Biota and Surface Water. Terrestrial biota radionuclides can be directly ingested by a human as crops, beef, or milk are consumed or through activities such as swimming or wading. Terrestrial biota radionuclides can exchange with surface water as cattle enter and leave streams.

Surface water radionuclides can be directly ingested by humans if surface water serves as a source of drinking water. These radionuclides can exchange with creek sediment and with aquatic biota, such as fish, because there is continual contact.

The third column of compartments consists of Creek Sediment and Aquatic Biota. The creek sediment radionuclides exchange with aquatic biota when plants or fish contact it. Creek sediments can directly affect a human wading in a stream. A human can directly ingest aquatic biota through consumption of fish, frogs, turtles, crayfish, or other aquatic creatures.

\subsubsection{Significance of Pathways}

In this section, rationale for determining the significance of pathways will be presented by working from right-to-left through Fig. 4.2-1. Special considerations for pathways are presented in the following subsection. 


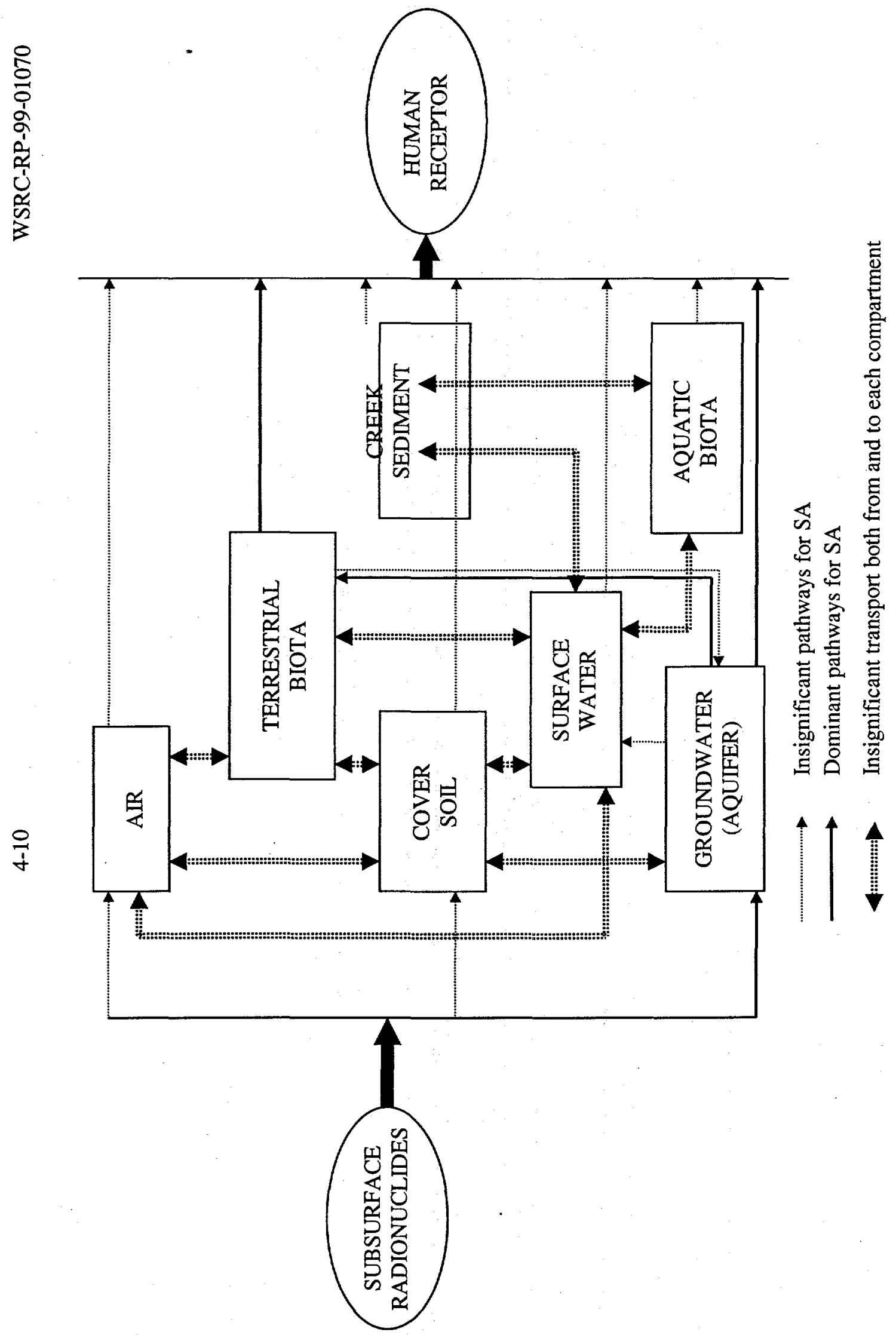


The third column of compartments consists of Creek Sediment and Aquatic Biota. Exposure from consuming contaminated fish, frogs, turtles, crayfish and similar aquatic creatures in the aquatic biota compartment is not considered to be significant health risk, because dilution is considerable in the nearby creeks. Groundwater radionuclide concentrations near the disposal units are expected to exceed surface water concentrations by orders of magnitude. Thus, ingestion of aquatic biota is expected to result in lower exposures than from direct ingestion of groundwater. A possible exception is C-14 in fish as shown in the Composite Analysis (WSRC $1997 \mathrm{~b}$ ), but C-14 is not applicable for the I-129 analysis in this report.

There is only slight opportunity for a human to be exposed to creek sediment compartment radionuclides. Concentrations in creek sediments likely will be much lower than concentrations in groundwater, causing radionuclides traveling along pathways through this compartment to be insignificant in terms of possible exposures.

The second column of compartments consists of Terrestrial Biota and Surface Water. There is a significant exposure risk from consumption of contaminated crops, beef, or milk in the terrestrial biota compartment. Groundwater is the primary compartment feeding the terrestrial biota compartment, hence arrows connecting the subsurface radionuclides, the groundwater compartment, the terrestrial biota compartment and the human receptor are all solid, thick lines. Little I-129 can reach the cover soil, except through irrigation. However, irrigation of cover soil by groundwater is practiced only occasionally in the SRS region, due to normally abundant precipitation during the growing season (Murphy 1990). Hence, although this pathway poses a significant risk, the risk is reduced by the limited irrigation.

There is only a slight exposure risk from surface water radionuclides, because concentrations are much lower than they are for the groundwater. Exchanges with terrestrial biota are much less significant than those from irrigation, because that exchange is primarily with deep-rooted trees that are not ingested by human receptors.

The first column of compartments consists of Air, Cover Soil and Groundwater (Aquifer). I-129 is not a highly volatile radionuclide so the air pathway is insignificant. There is only a slight exposure risk from cover soil radionuclides, because direct human ingestion is minimal. Direct ingestion by a human of the groundwater radionuclides is significant, due to high concentrations. The arrows from the subsurface radionuclides to the groundwater compartment and to the human receptor thus are solid, thick lines.

Based on the discussion above, only two sets of transport pathways are considered to be of significant consequence to off-site members of the public and are considered further in this SA. These pathways, indicated by solid arrows in Fig. 4.2-1, include:

1) leaching of the waste form resulting in contamination of groundwater local to $E$ Area and direct ingestion of that groundwater

2) leaching of the waste form resulting in contamination of groundwater local to $\mathrm{E}$ Area, irrigation of livestock and crops, and ingestion of meat and milk from livestock that drink the contaminated irrigation water or ingestion of crops irrigated with that groundwater 


\subsubsection{Special Considerations for Pathways}

Both pathways of concern in the all-pathways analysis include groundwater. A special consideration for the groundwater pathway is contaminant movement as colloids. Radionuclides may move through groundwater either as dissolved constituents or in a suspended colloidal form. Colloidal migration is a very dynamic process. As suspended colloids encounter slight changes in water chemistry or flow rate along a flow path, they may either deposit on the immobile soil surfaces or become mobilized. Therefore, colloidal transport in natural aquifer media can be viewed as a process with attributes similar to those governing sorption and desorption of elements and compounds. Colloidal forms are not explicitly addressed in this analysis for two reasons, discussed below.

First, colloidal forms are not directly addressed in this analysis because reliable means of predicting site-specific colloidal influences on solute migration are not available. The types of colloids present are not readily measured, and thus the sorptive potential and stability of the colloids cannot be projected. Second, colloids migrate according to complex physical and chemical immobilization and remobilization mechanisms. These mechanisms are not easily determined in non-idealized media such as natural aquifer materials. Because of these and other uncertainties, conservative assumptions are used in the SA to assure that these indeterminate effects attributable to colloids will not have a significant influence on the results.

For liquid transport computations used in this analysis, a sorption coefficient, normally referred to as a $K_{d}$, is used to represent the partitioning of a radionuclide between the solid and liquid phases. Coefficients for each radionuclide are empirically determined and are calculated from experimental tests that either measure "liquid phase" and solid phase concentrations of radionuclides or measure the retardation that occurs as a result of reversible sorption processes when liquid constituents move through a porous medium. "Liquid phase" in both of these measurements is defined as that portion of the experimental media that passes through a filter of a specified pore size. Because of this definition, the "liquid phase" may actually contain colloids that pass through the filter. This colloidal material is very sorptive because the particles are small with a very high surface-to-volume ratio. Thus, the colloidal fraction passing through the filter with the liquid tends to artificially increase the "liquid phase" concentration, which decreases the $\mathrm{K}_{\mathrm{d}}$ of the porous media being tested. Because an experimental $\mathrm{K}_{d}$ may be too low, calculated doses from liquid pathways will be conservative.

\subsubsection{Receptor Locations}

The nearest location from the disposal site for off-site members of the public depends on the time after disposal. During the period of active institutional control, i.e., for the first 100 years after facility closure, off-site members of the public are assumed to be located no closer to the disposal site than the present boundary of the SRS. After active institutional control ceases, off-site members of the public could be located as close as $100 \mathrm{~m}$ from any of the E-Area disposal units (the buffer stated in DOE Order 435.1, DOE 1999a). 
Doses to the off-site public from contaminated groundwater exposure pathways at $100-\mathrm{m}$ distances from the disposal units are not considered during active institutional control due to the following reasons:

1) the design and closure concepts for the disposal units that are intended to inhibit infiltration of precipitation, and

2) the considerable distance from the disposal site to the present boundary of the SRS.

Thus, during the period of active institutional control, the closest member of the public is considered to be at the SRS site boundary. Doses during the active institutional control period are ignored, because the doses at the site boundary should be much lower than later doses from 100$m$ well water. During the active institutional control period contaminated groundwater will discharge to surface streams within the SRS and considerable dilution will be provided by the streams.

In summary, for dose analyses an off-site member of the public is assumed to use water from a well for domestic purposes. That well is assumed to be at least $100 \mathrm{~m}$ from the vaults where the maximum concentrations of radionuclides in groundwater are projected to occur after loss of active institutional control.

\subsubsection{Water Resource Impacts Analysis}

The information in this section is summarized from sections 2.5.2 and 4.2.3 of the PA revision (WSRC 2000), except that this report is limited to I-129. In the PA revision, three options were considered to develop the performance measure for the water resource impacts analysis.

In the first option, the MCLs for radionuclides in groundwater are those specified in current EPA standards (promulgated in 1976) for radioactivity in drinking water. The current standards include: 1) a limit on concentration of $5 \mathrm{pCi} / \mathrm{L}$ for ${ }^{226} \mathrm{Ra}$ and ${ }^{228} \mathrm{Ra}$ combined; 2) a limit on concentration of $15 \mathrm{pCi} / \mathrm{L}$ for gross alpha-particle activity, including ${ }^{226} \mathrm{Ra}$ but excluding radon and uranium; and 3) a limit on dose equivalent to whole body or any organ of 4 mrem per year from all man-made beta/gamma-emitting radionuclides. The current standards also specify that the calculation of the concentration of any man-made beta/gamma-emitting radionuclide causing a dose equivalent of 4 mrem to whole body or any organ shall be based on a drinking water intake of $2 \mathrm{~L} /$ day and data for converting activity intakes of radionuclides to doses published by the U.S. Department of Commerce (DOC) (1963). Two exceptions are that the MCLs of $20,000 \mathrm{pCi} / \mathrm{L}$ for tritium $\left({ }^{3} \mathrm{H}\right)$ and $8 \mathrm{pCi} / \mathrm{L}$ for ${ }^{90} \mathrm{Sr}$ are prescribed.

The second option is the same as the first, except the concentration of beta-gamma emitting radionuclides are determined using updated dosimetry data. The third option used the MCLS proposed by the EPA in 1991. These options were developed to aid in determining the appropriate performance measure. Interpretation of the CERCLA regulation indicated that option 1 (i.e., current drinking water standards) must be used.

The I-129 Maximum Contaminant Levels (MCLs) for the three options of specifying the performance measure for groundwater impacts analysis are given in Table 4.2-3. All MCLs are given in units of $\mathrm{pCi} / \mathrm{L}$ to facilitate comparisons of the different options, even though the primary standard for beta/gamma-emitting radionuclides in all options is a dose limit rather than a limit on concentration. 
Table 4.2-3 Maximum Contaminant Levels for Radionuclides in Groundwater Corresponding to Different Options of Groundwater Impacts Requirements ${ }^{\mathrm{a}}$

\begin{tabular}{clll}
\hline Radionuclide & ${\text { Option } 1^{\mathrm{b}}}^{\mathrm{b}}$ & Option $2^{\mathrm{b}}$ & Option $3^{\mathrm{b}, \mathrm{c}}$ \\
\hline${ }^{129} \mathrm{I}$ & 0.5 & 0.6 & 21 \\
\hline
\end{tabular}

${ }^{a}$ Different options are described in Section 2.5.2 of WSRC 2000 and Section 4.2.2.

${ }^{b}$ Values are in units of $\mathrm{pCi} / \mathrm{L}$, unless otherwise noted.

c Value calculated by EPA (1991), unless otherwise noted.

To compare the dose from the drinking water pathway relative to the dose from the milk and meat pathways, ${ }^{129} \mathrm{I}$ was examined using an $\mathrm{F}_{\mathrm{m}}$ of 0.01 and an $\mathrm{F}_{\mathrm{f}}$ of $7.0 \mathrm{E}-3$ (Baes, et. al 1984). The drinking water pathway dose is more than 7 times greater than the dose from the milk and meat pathways.

\subsection{Analysis Method}

The conceptual models developed for analyzing potential transport for radionuclides from the IL Vault disposal units of E Area to the points of compliance associated with the performance objectives are described in this section. Methods used to implement these models, assumptions made in implementation, and justification for the assumptions are also discussed.

\subsubsection{All-Pathways Analysis}

Based on the discussion in Section 4.2.2 the only I-129 exposure pathway of concern for the allpathways analysis is the pathway that involves direct ingestion of groundwater. In large part, the analysis of this pathway is identical to that for the water-resource impacts analysis, and thus is described in Section 4.3.2. Doses to the off-site members of the public from ingesting contaminated groundwater beyond the $100-\mathrm{m}$ buffer zone around all disposal units were not directly estimated. Rather, comparisons of maximum projected groundwater concentrations with the more restrictive of either MCLs (Table 4.2-3) or allowable concentrations based on the 25mrem per year performance objective were made. The allowable concentrations were calculated by dividing the 25 mrem per year value by the EDE per unit concentration in drinking water (Table B.3-5, Appendix B.3). A composite listing of MCLs and allowable concentrations based on the $25 \mathrm{mrem} / \mathrm{yr}$ limit is given in Table $4.3-1$.

Table 4.3-1 Comparison of MCLs and Allowable Groundwater Concentrations Based on the 25 mrem Per Year Performance Objective for Off-Site Individuals

\begin{tabular}{lcl}
\hline Radionuclide & $\begin{array}{c}\mathrm{MCL},{ }^{\mathrm{a}} \\
\mathrm{pCi} / \mathrm{L}\end{array}$ & Allowable Concentration Based on 25 mrem per Year, $\mathrm{pCi} / \mathrm{L}^{\mathrm{b}}$ \\
\hline${ }^{129} \mathrm{I}$ & 0.5 & 130 \\
\hline a & Option 1, Table 4.2-3. & \\
b & Calculated from Table B.3-5
\end{tabular}




\subsubsection{Water-Resource Impacts Analysis}

The analysis for water-resource impacts requires that transport of radionuclides from the waste disposal units to the compliance points for groundwater impacts (Section 2.5.2 in WSRC 2000) be simulated. To conduct these simulations, conceptual models were developed representing the disposal units and surrounding vadose zone to facilitate computation of radionuclide transport to the aquifer. A conceptual model for transport in the saturated zone was also developed. The conceptual models define how features of the disposal units and the subsurface environment are represented in the numerical models used to conduct the transport simulations. The key assumptions and values of parameters assumed for this analysis are described below.

Conceptual models of radionuclide transport are of two main types: models describing vadose, or unsaturated, zone transport (which include transport through disposal unit barriers); and a model describing transport through the saturated zone beneath the water table to the point of compliance. The vadose zone model is unique to the disposal unit's design characteristics that influence the flow of water and transport of radionuclides through the materials present. The saturated zone model represents the aquifer units underneath all E-Area disposal units; therefore, only one saturated zone conceptual model is needed for the entire facility.

Results of the saturated zone model simulations are reported in terms of the maximum groundwater concentration at the compliance point per $\mathrm{Ci}$ of each radionuclide disposed in an $\mathrm{IL}$ Vault. This fractional concentration is compared to the MCL or to the allowable concentration based on the 25-mrem all-pathways performance objective, when the latter is more restrictive than MCL (see Section 4.2.2). This comparison (dividing the MCL by the fractional concentration) yields an inventory limit for each radionuclide, which is reported in Section 5.

\subsubsection{Vadose Zone Model of IL Vaults}

Release of radionuclides from the IL vaults to the vadose zone will occur when water enters the vaults, contacts the waste, dissolves or desorbs radionuclides, and subsequently exits the vaults (Section 4.1.3). Diffusion may also occur. Factors affecting this release are the rates of water movement through the vaults and waste and the solubility, sorption, and decay characteristics of the radionuclides. Once in the surrounding vadose zone, transport of radionuclides will be influenced by the same factors, but for different materials through which the radionuclides travel.

The conceptual model of the IL vaults considers movement of water and radionuclides through the vadose zone and waste disposal units in 2-dimensions. The 2-dimensional model represents the right half of a transverse section through an IL vault and the surrounding porous media, as shown in Fig. 4.3-1. Analysis in 2-dimensions is sufficient for this problem, because releases along the length of the vaults are expected to be uniform except at each end of a vault. Releases from the end-planes of the vaults are expected to be insignificant relative to releases from the combined areas represented by the bottoms and sides of the vaults, and thus no corrections are made to account for these releases. The results in 2-dimensions, which assume a unit width in the third dimension, are readily adapted to 3 -dimensions. 
The upper part of the domain of the IL vault conceptual model is the ground surface (Fig 4.3-1). The lower part of the domain is the water table. Directly beneath the ground surface is top soil, underlain by the sloped ( $2 \%$ grade) gravel and clay layers of the infiltration barrier. Water prohibited from infiltrating by the clay layer is assumed to flow to a conceptual drain, representing any means of diverting water from the vaults. It is assumed that drainage around individual vaults is sufficient to carry excluded water away from the vaults during the time that the infiltration barrier is intact (100 years). Underneath the infiltration barrier is the backfill used to fill under, to the sides, and over the constructed and filled vaults. Finally, the concrete roof, walls, and floor of the vaults are represented, as well as the waste placed in the vaults. The base

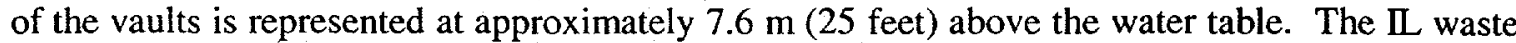
is to be grouted in place or enclosed in concrete. However, the grout is only assumed to maintain a high $\mathrm{pH}$ level which actually reduces the $K_{d}$ for I-129 (Kaplan, 1999). The entire waste volume was assumed to consist only of the waste form. Although voids will exist for tritium crucibles and some other waste forms, release from the vaults during the intact phase will be controlled by high $\mathrm{Kd}$ waste. A discretization of the IL vault domain is shown in Fig. 4.3-2.

The barrier at the right side of the IL vault domain, adjacent to the drain, represents a location far enough from the vaults that flow is expected to be vertical and unaffected by the flow of water diverted around the low permeability vaults. No lateral flow is expected at this location and an imaginary barrier was added so that water from the conceptual drain does not reenter the interior of the domain at this point. The left side of the IL vault domain is a line of symmetry midway through the transverse section of the IL vault. Symmetry forces flow at this point to be vertical.

The conceptual model for the $\mathrm{IL}$ vault depicted in Fig. 4.3-1 defines the vertical and lateral extent of the simulation domain used to perform flow and mass transport computations. The domain discretization (Fig. 4.3-2) includes about 2700 small elements (a $43 \times 63$ grid) for which the flow and transport equations are solved numerically. The PORFLOW code (Appendix B of WSRC 2000) was used for flow and transport simulations.

To solve the flow equations, boundary conditions and hydraulic properties of the materials present in the simulation domain were specified. The top of the domain is a constant flux boundary, where net infiltration (rainfall less evapotranspiration and other losses) is applied. An infiltration rate of $40 \mathrm{~cm} / \mathrm{yr}$ is assumed (Appendix B). The bottom of the domain is a constant head boundary, maintained by the presence of the water table. The left and right boundaries are no flow boundaries, where flow is essentially vertical and parallel to these boundaries, as described above.

Hydraulic properties of the materials present in the simulation domain were assigned according to a complex rationale described in Appendix C of WSRC 2000. Assignment of these properties requires spatial averaging, such that each of these materials is treated as if they are homogeneous and isotropic porous media. These properties change with time, according to the degree of degradation assumed to have occurred in the vaults. For the $\mathrm{IL}$ vaults, three different conditions occur over time (Table 4.1.3, Section 4.1.3, of WSRC 2000):

- the intact condition, occurring from the time of closure to 575 years post-closure

- the degraded condition, occurring between 575 and 1050 years post-closure

- the failed condition, occurring after roof failure, which is estimated to occur at 1050 years post-closure (Appendix D of WSRC 2000). 


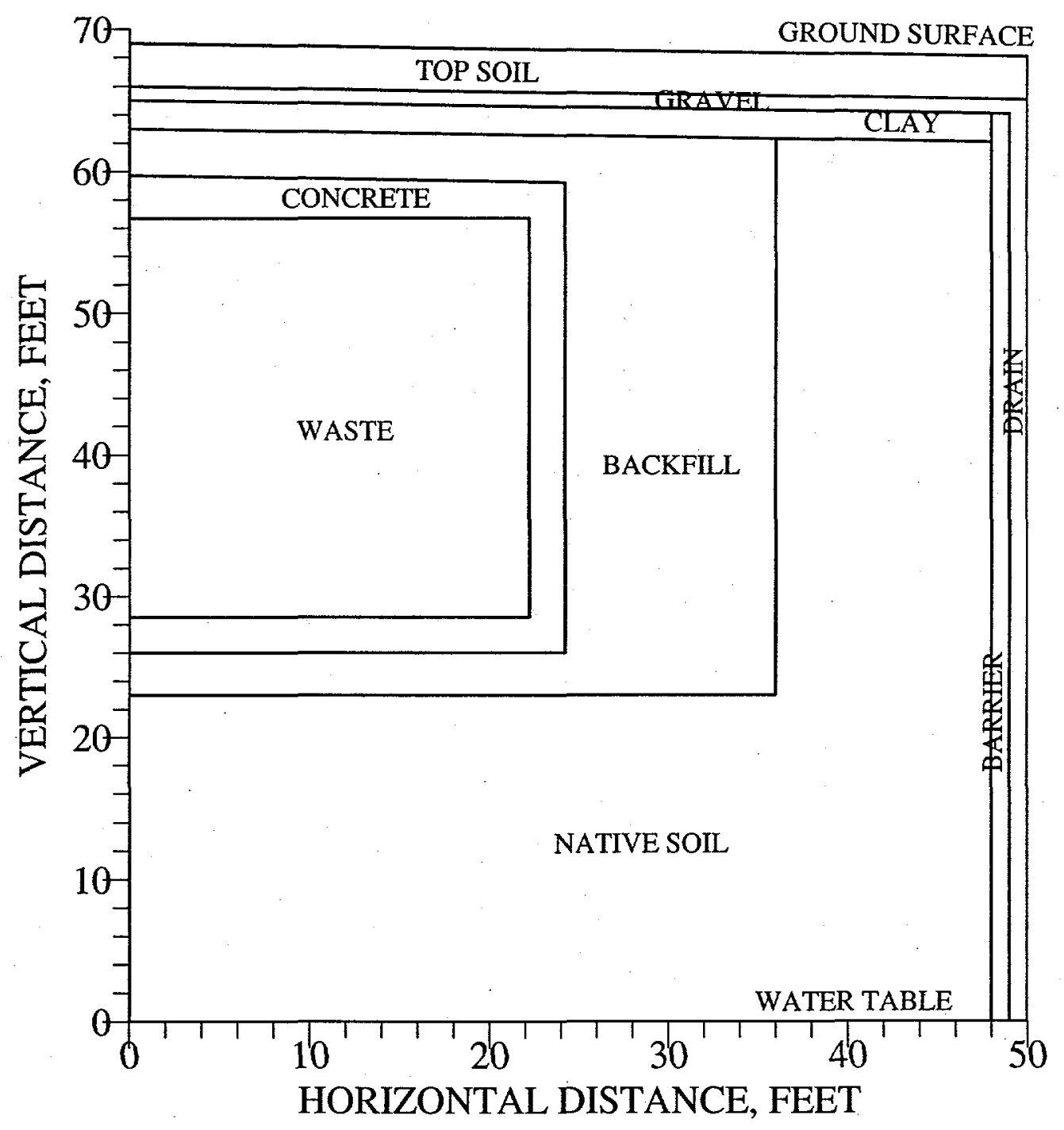

Figure 4.3-1. Conceptual model of IL vault 


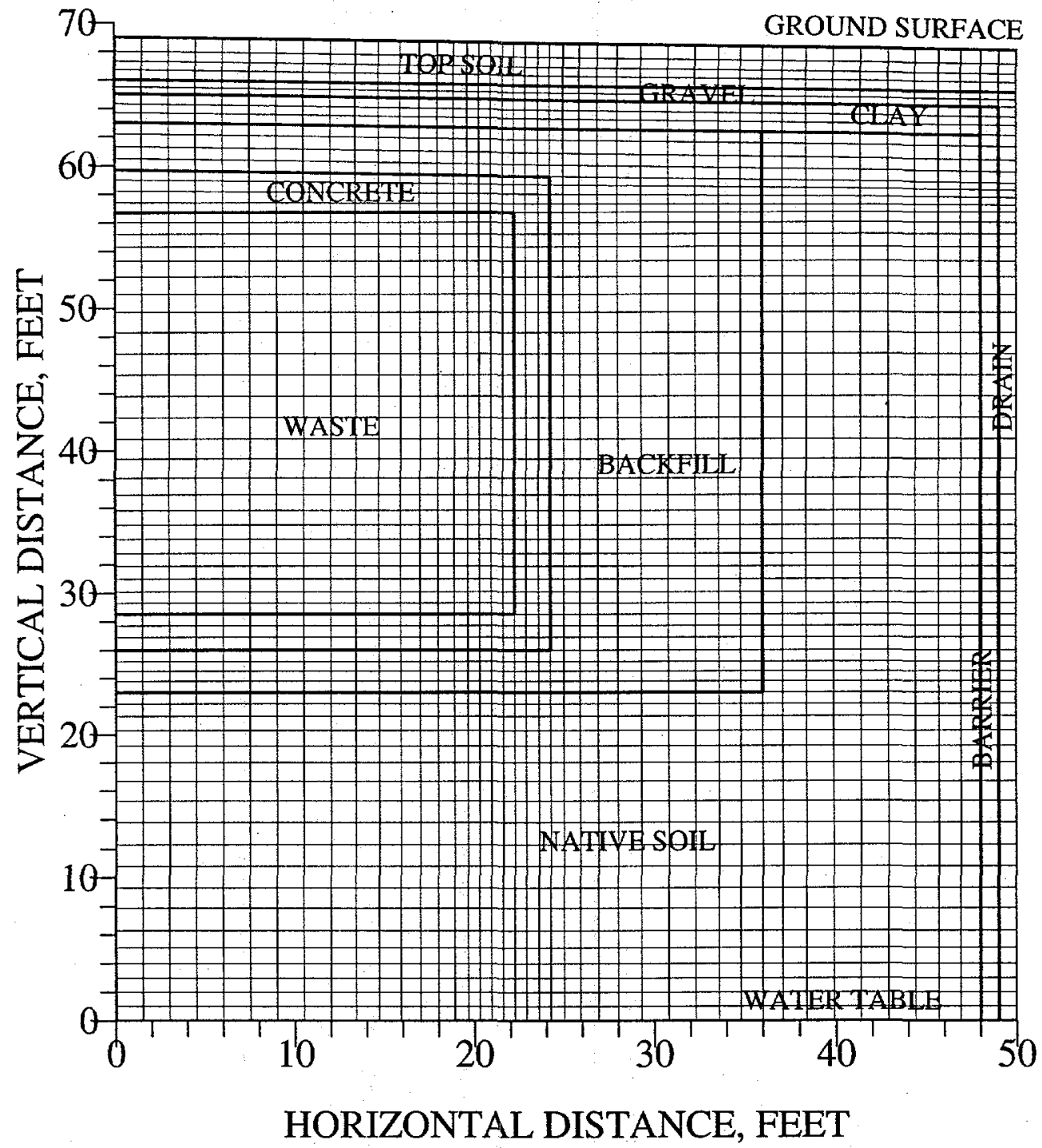

Figure 4.3-2. Modeling grid of IL vault 
Table 4.3-2 lists the hydraulic conductivity, porosity, and type of moisture characteristic curve assumed for each material under these three conditions. Steady-state simulations of flow were conducted for the three conditions defined for the IL vaults.

Table 4.3-2 Hydraulic Conductivity, Porosity, and Characteristics of Materials in IL Vault Conceptual Model

\begin{tabular}{|c|c|c|c|c|c|c|c|}
\hline \multirow[b]{3}{*}{ Material. } & \multirow{2}{*}{\multicolumn{3}{|c|}{$\begin{array}{r}\text { Hydraulic Conductivity (cm/s) } \\
\text { Scenario (years) }\end{array}$}} & \multirow{2}{*}{\multicolumn{2}{|c|}{$\begin{array}{l}\text { Porosity Characteristic C } \\
\text { Scenario (years) }\end{array}$}} & \multirow{2}{*}{\multicolumn{2}{|c|}{$\begin{array}{l}\text { urve Used } \\
\text { Scenario (years) }\end{array}$}} \\
\hline & & & & & & & \\
\hline & $\begin{array}{l}\text { Intact } \\
\text { (0 to 575) }\end{array}$ & $\begin{array}{l}\text { Degraded } \\
(575 \text { to } 1050)\end{array}$ & $\begin{array}{l}\text { Failed } \\
\text { (1050 and up) }\end{array}$ & $\begin{array}{l}\text { All } \\
\text { (0 and up) }\end{array}$ & $\begin{array}{l}\text { Intact } \\
\text { (0 to } 575 \text { years) }\end{array}$ & $\begin{array}{l}\text { Degraded } \\
\text { (575 to 1050) }\end{array}$ & $\begin{array}{l}\text { Failed } \\
\text { (1050 and up) }\end{array}$ \\
\hline Top Soil & $1 \times 10^{-3}$ & $1 \times 10^{-3}$ & $1 \times 10^{-3}$ & 0.38 & Top Soil & Top Soil & Top Soil \\
\hline Gravel & $1 \times 10^{-2}$ & $1 \times 10^{-2}$ & $1 \times 10^{-3}$ & 0.38 & Gravel & Gravel & Top Soil \\
\hline Clay & $1 \times 10^{-6}$ & $1 \times 10^{-6}$ & $1 \times 10^{-5}$ & 0.57 & Clay & Clay & Native Soil \\
\hline Backfill Soil & $1 \times 10^{-6}$ & $1 \times 10^{-6}$ & $1 \times 10^{-5}$ & 0.51 & Backfill Soil & Backfill Soi] & Native Soil \\
\hline Native Soil & $1 \times 10^{-5}$ & $1 \times 10^{-5}$ & $1 \times 10^{-5}$ & 0.42 & Native Soil & Native Soil & Native Soil \\
\hline Concrete & $1 \times 10^{-10}$ & $1 \times 10^{-7}$ & $1 \times 10^{-5}$ & 0.18 & Concrete & Backfill Soil & Native Soil \\
\hline Waste & $1 \times 10^{-10}$ & $1 \times 10^{-7}$ & $1 \times 10^{-5}$ & 0.18 & Concrete & Backfill Soil & Native Soil \\
\hline Drain & $1 \times 10^{-1}$ & $1 \times 10^{-1}$ & $1 \times 10^{-5}$ & 0.38 & Gravel & Gravel & Native Soil \\
\hline Barrier & $1 \times 10^{-10}$ & $1 \times 10^{-10}$ & $1 \times 10^{-5}$ & 0.18 & Concrete & Concrete & Native Soil \\
\hline
\end{tabular}

Mass transport simulations were run using the steady-state flow fields generated for all three scenarios, and were based on an initial activity of $1 \mathrm{Ci}$ of I-129 present in one IL vault. Simulations were conducted for each type of I-129 waste using its measured $\mathrm{K}_{\mathrm{d}}$. Boundary conditions for mass transport were assumed as follows: at the top and bottom of the domain, a concentration of zero was assigned, which corresponds to the assumption that contaminants reaching either boundary are rapidly swept away from the vicinity of contact. This assumption serves to maximize the simulated diffusive flux through the domain, which is driven by concentration gradients, and thus, is conservative. At the left side of the domain, a no-flux boundary was assigned because of symmetry with the left half of the vault. At the right side of the domain, a no-flux boundary was assigned because of the drain.

$\mathrm{K}_{\mathrm{d}}$ 's listed in Table 4.1-3 were used for each I-129 waste form. Apparent diffusion coefficients from Table 4.1-5 were assumed. Longitudinal and transverse dispersivities were assumed to be zero $\mathrm{cm}$. This assumption may delay simulated arrival of the leading edge of a plume at the water table slightly, but it is conservative because the plume is more concentrated by neglecting dispersion. Estimated fluxes at the water table are reported as $\mathrm{Ci} / \mathrm{yr}$ per $\mathrm{Ci}$ initially in the disposal unit. These reporting units facilitate calculation of inventory limits, and are readily scaled to the initial inventory of each radionuclide listed in Appendix A.

Peak fractional fluxes to the water table for I-129 waste forms simulated are given in Table 4.3-3. Hypothetical waste forms with $K_{d}$ s that were expected to cover the $K_{d}$ range for actual waste were also modeled and their peaks are shown in Table 4.3-3. The peak fluxes for all waste forms occur soon after roof failure, which is estimated to occur at 1050 years.

This peaking behavior occurs primarily because of the jump in infiltration when the roof fails. The volumetric flow is increased by the jump in water speed accompanied by an increase in the volume of water present in the vadose zone as the saturation increases. For all cases, once contamination is released from the waste it moves rather quickly through the underlying materials because the I-129 $\mathrm{K}_{d}$ is low in each material. I-129 in concrete has a low $\mathrm{K}_{d}$ of $2 \mathrm{ml} / \mathrm{g}$ and I-129 in the underlying vadose zone materials has an even lower $\mathrm{K}_{d}$ of $0.6 \mathrm{ml} / \mathrm{g}$. Movement through the aquifer is quick because of the high aquifer water speed and the low I-129 $\mathrm{K}_{\mathrm{d}}$. 
Table 4,3-3. Estimated peak fractional flux to the water table for I-129 waste forms

\begin{tabular}{|c|c|c|c|c|c|}
\hline $\begin{array}{c}\text { I-129 } \\
\text { Waste Form }\end{array}$ & $\begin{array}{c}\mathbf{K}_{\mathbf{d}} \\
\mathrm{ml} / \mathrm{g}\end{array}$ & $\begin{array}{c}\text { Peak fractional } \\
\text { flux to water } \\
\text { table } \\
\mathrm{Ci} / \mathrm{yr} \text { per } \mathrm{Ci} \\
\text { inventory } \\
\end{array}$ & $\begin{array}{c}\text { Time of } \\
\text { peak flux } \\
\text { Yr } \\
\end{array}$ & $\begin{array}{c}\text { Peak Normalized } \\
\text { Concentration at } \\
100-m \text { Well } \\
\text { PCi/L per Ci } \\
\text { inventory }\end{array}$ & $\begin{array}{c}\text { Time of } \\
\text { peak flux } \\
\text { Yr } \\
\end{array}$ \\
\hline Hypothetical & 2 & $1.63 \mathrm{E}-2$ & 1100 & 975.5 & 1120 \\
\hline Hypothetical & 20 & $1.71 \mathrm{E}-3$ & 1120 & 104.8 & 1140 \\
\hline Hypothetical & 200 & $1.71 \mathrm{E}-4$ & 1120 & 10.52 & 1140 \\
\hline $\begin{array}{l}\text { Activated } \\
\text { Carbon }^{\mathrm{a}}\end{array}$ & 600 & $5.70 \mathrm{E}-5$ & 1120 & 3.506 & 1140 \\
\hline Hypothetical & 1000 & $3.42 \mathrm{E}-5$ & 1120 & 2.104 & 1140 \\
\hline $\begin{array}{l}\text { Dowex } 21 \mathrm{~K} \\
\text { Resin }\end{array}$ & 2800 & $1.90 \mathrm{E}-5$ & 1120 & 1.169 & 1140 \\
\hline Hypothetical & 2000 & $1.71 \mathrm{E}-5$ & 1120 & 1.052 & 1140 \\
\hline GT-73 & 3100 & $1.10 \mathrm{E}-5$ & 1120 & 0.6786 & 1140 \\
\hline
\end{tabular}

${ }^{a}$ Waste form planned for disposal in IL Vaults

\subsubsection{Saturated Zone Model of E Area}

\subsection{Model Types}

To calculate peak groundwater concentrations at the points of compliance for the all-pathways analysis and water-resource impacts analysis, transport in the saturated zone of radionuclides leached from the waste disposal units and reaching the water table must be evaluated. There are two main components to this evaluation: 1) development and simulation of a saturated flow model; and 2) development and simulation of a contaminant transport model for the saturated zone.

\subsection{Numerical Flow Model}

The numerical flow model for the IL Vaults is identical to that for cement-stabilized encapsulated waste trenches at the E-Area LLWF. Thus, Section 4.3.3.2.2 in WSRC 2000 provides the needed description of the numerical flow model for this SA.

\subsection{Numerical Transport Model}

The numerical transport model for the $\mathrm{IL}$ Vaults is identical to that for cement-stabilized encapsulated waste trenches at the E-Area LLWF. Thus, Section 4.3.3.2.3 in WSRC 2000 provides the needed description of the numerical transport model for this SA. The only difference is that the source term is produced in the IL Vault, rather than in trenches.

Locations of the IL Vaults were interpreted in terms of this simulation grid. Two vaults were represented on this grid as shown in Figure 4.3-5. Results of the transport simulations are provided in tables in Section 5 and shown graphically in Appendix C. 


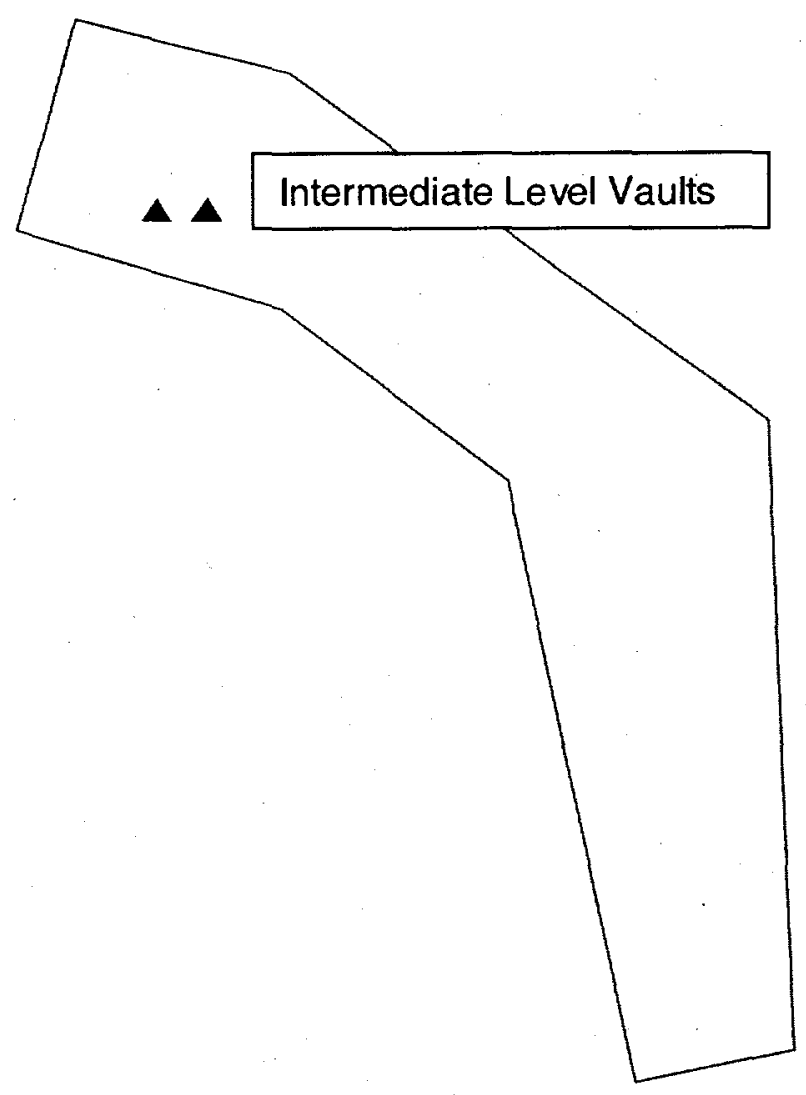

Figure 4.3-5. Location of the IL Vaults 
THIS PAGE INTENTIONALLY LEFT BLANK 
SECTION 5

RESULTS OF NON-INTRUDER ANALYSES 
THIS PAGE INTENTIONALLY LEFT BLANK

Rev. 1

July 31,2000 


\section{RESULTS OF NON-INTRUDER ANALYSES}

In this section, the results of the analysis of performance of the IL Vaults in the E-Area LLWF are presented for non-intruder scenarios. As described in Section 4.2, the analyses focus on ingestion of radionuclides in groundwater for the all-pathways and water-resource impacts analysis. In Section 5.1, projected groundwater concentrations and calculated inventory limits used in evaluating performance objectives for protection of the public and performance requirements to assess water-resource impacts (Section 2.5) are presented. In Section 5.2, the results of sensitivity and uncertainty analyses are discussed, to gain perspective on the meaning of the results in Section 5.1. Finally, in Section 5.3, application of the As Low As Reasonably Achievable (ALARA) process to the design and operation of the IL Vaults in the E-Area LLWF is discussed.

\subsection{Results of All-Pathways Analysis and Water-Resource Impacts Analysis}

Section 4.2 established that the only significant pathway of concern for the all-pathways analysis is groundwater ingestion, with the endpoint of the analysis being evaluation of dose. The endpoint of the water-resource impacts analysis is estimated groundwater concentrations at the same compliance point as that used in evaluating protection of the public: the point of highest concentration outside a $100-\mathrm{m}$ buffer zone around disposal units. The performance objective of $25 \mathrm{mrem} / \mathrm{yr}$ for protection of the public in the all-pathways analysis can readily be converted to an allowable groundwater concentration limit. The $25 \mathrm{mrem} / \mathrm{yr}$ limit is divided by the EDE of any given radionuclide per unit concentration in groundwater (Table 5.1-1). Therefore, endpoints of performance measures for protection of the public and analysis of water-resource impacts can both be expressed in terms of groundwater concentration in this SA. The following discussion addresses results of the all-pathways analysis and water-resource impacts analysis together, because the same calculated groundwater concentrations can be used to evaluate each performance measure.

Table 5.1-1 Annual EDEs from Drinking Water Pathway Per Unit Concentration of Radionuclides in Water

\begin{tabular}{ll}
\hline & EDE \\
Radionuclide & rem/yr per $\mu \mathrm{Ci} / \mathrm{L}$ \\
\hline${ }^{129} \mathrm{I}$ & $2.0 \mathrm{E}+02$ \\
\hline
\end{tabular}

The methods for calculating groundwater concentrations at the compliance point for protection of the public and for water-resource impacts analysis were described in Section 4.3. Briefly, groundwater concentrations at the compliance point were calculated by using the vadose zone models (simulated with PORFLOW) to calculate contaminant flux to the water table as a function of time. Fractional fluxes ( $\mathrm{Ci} / \mathrm{yr}$ per $\mathrm{Ci}$ disposed) were estimated and used as the source term to the saturated zone model. Groundwater concentrations ( $\mathrm{pCi} / \mathrm{L}$ per $\mathrm{Ci}$ disposed) were then calculated using PORFLOW. Results of the PORFLOW analyses are shown graphically in Appendix C. 
The greundwater concentrations presented in this section are in normalized units $(\mathrm{pCi} / \mathrm{L}$ per $\mathrm{Ci}$ ) to facilitate computation of inventory limits for IL Vaults. Ultimately, the more restrictive of either the MCLs (in $\mathrm{pCi} / \mathrm{L}$ ) or allowable concentrations (in $\mathrm{pCi} / \mathrm{L}$ ) based on the $25 \mathrm{mrem} / \mathrm{yr}$ performance objective can be divided by the normalized groundwater concentrations to derive an inventory limit. Calculated inventory limits, based on the peak groundwater concentrations, are also presented in this section.

Table 5.1-2 provides the maximum projected groundwater concentrations of radionuclides at the compliance point for protection of the public and for water-resource impacts analysis, normalized to a one- $\mathrm{Ci}$ source of each waste form listed in the inventory (Appendix A). In Table 5.1-3, calculated inventory limits based on the peak groundwater concentrations up to 10,000 years are given. Inventory limits for two vaults are calculated by dividing the concentration limit by the peak groundwater concentration. Because flux results from the vadose zone model were split between two cells in the aquifer model (representing locations below two IL Vaults), the inventory limits for one vault is calculated by halving the limit for two vaults.

The inventory limits form an essentially linear relationship with the $\mathrm{K}_{\mathrm{d}}$. The data points from Table 5.1-3 are plotted in Figure 5.1-1. The best-fit linear equation is as follows:

$$
\text { Inventory Limit }(\mathrm{Ci} / \text { vault })=1.188 \mathrm{E}-4 * \mathrm{~K}_{\mathrm{d}}(\mathrm{ml} / \mathrm{g})+1.504 \mathrm{E}-6
$$

The data are more nearly linear at the higher $\mathrm{K}_{\mathrm{d}}$ values. This equation can be used to estimate the inventory limits for high-concentration I- 129 wastes with measured $\mathrm{K}_{d}$ values.

\subsection{Results of the Sensitivity and Uncertainty Analysis}

The sensitivity and uncertainty analysis is discussed in the similarly titled section in the PA revision (WSRC 2000).

\subsection{ALARA Analysis}

The ALARA analysis is discussed in the similarly titled section in the PA revision (WSRC 2000). 
Table 5.1-2 Peak Groundwater Concentrations for the High-Concentration I-129 Waste Simulations

\begin{tabular}{lccc}
\hline Waste Form & $\begin{array}{c}\mathrm{Kd} \\
\mathrm{ml} / \mathrm{g}\end{array}$ & $\begin{array}{c}\text { Peak up to } 10,000 \text { years } \\
\mathrm{pCi} / \mathrm{L} \text { per } \mathrm{Ci}\end{array}$ & $\begin{array}{c}\text { Time of peak } \\
\mathrm{yr}\end{array}$ \\
\hline Hypothetical & 2 & 975.5 & 1120 \\
Hypothetical & 20 & 104.8 & 1140 \\
Hypothetical & 200 & 10.52 & 1140 \\
Activated Carbon & 600 & 3.506 & 1140 \\
Hypothetical & 1000 & 2.104 & 1140 \\
Dowex 21K & 2800 & 1.169 & 1140 \\
Hypothetical & 2000 & 1.052 & 1140 \\
GT-73 & 3100 & 0.6786 & 1140 \\
\hline
\end{tabular}

${ }^{a}$ Estimated with PORFLOW

${ }^{b}$ Waste form planned for disposal in IL Vaults

Table 5.1-3 Peak Groundwater Concentrations for the High-Concentration I-129 Waste Simulations

\begin{tabular}{|c|c|c|c|c|}
\hline Waste Form & $\begin{array}{l}\mathrm{K}_{\mathrm{d}} \\
\mathrm{ml} / \mathrm{g}\end{array}$ & $\begin{array}{l}\mathrm{MCL}^{\mathrm{a}} \\
\mathrm{pCi} / \mathrm{L}\end{array}$ & $\begin{array}{l}\text { Peak groundwater } \\
\text { concentration up to } \\
10,000 \text { years } \\
\text { pCi } / \mathrm{L} \text { per } \mathrm{C} i\end{array}$ & $\begin{array}{c}\text { Calculated inventory } \\
\text { limit }^{\mathrm{c}} \\
\mathrm{Ci} / \text { vault }^{2}\end{array}$ \\
\hline Hypothetical & 2 & .5 & 975.5 & $2.56 \mathrm{E}-4$ \\
\hline Hypothetical & 20 & .5 & 104.8 & $2.39 \mathrm{E}-3$ \\
\hline Hypothetical & 200 & .5 & 10.52 & $2.38 \mathrm{E}-2$ \\
\hline Activated Carbon & 600 & .5 & 3.506 & $7.14 \mathrm{E}-2$ \\
\hline Hypothetical & 1000 & .5 & 2.104 & $1.19 \mathrm{E}-1$ \\
\hline Dowex $21 \mathrm{~K}$ & 2800 & .5 & 1.169 & $2.08 \mathrm{E}-1$ \\
\hline Hypothetical & 2000 & .5 & 1.052 & 2.27E-1 \\
\hline GT-73 & 3100 & .5 & 0.6786 & $3.57 \mathrm{E}-1$ \\
\hline
\end{tabular}

a The MCL is more restrictive than the allowable concentration based on a $25 \mathrm{mrem} / \mathrm{yr}$ performance objective (Table 4.3-1)

b Peak concentration is per Ci disposed of in two IL Vaults.

c Calculated by dividing the "Concentration limit" by the "Peak groundwater concentration" and dividing by 2 to normalize to one IL Vault.

Waste form planned for disposal in IL Vaults 


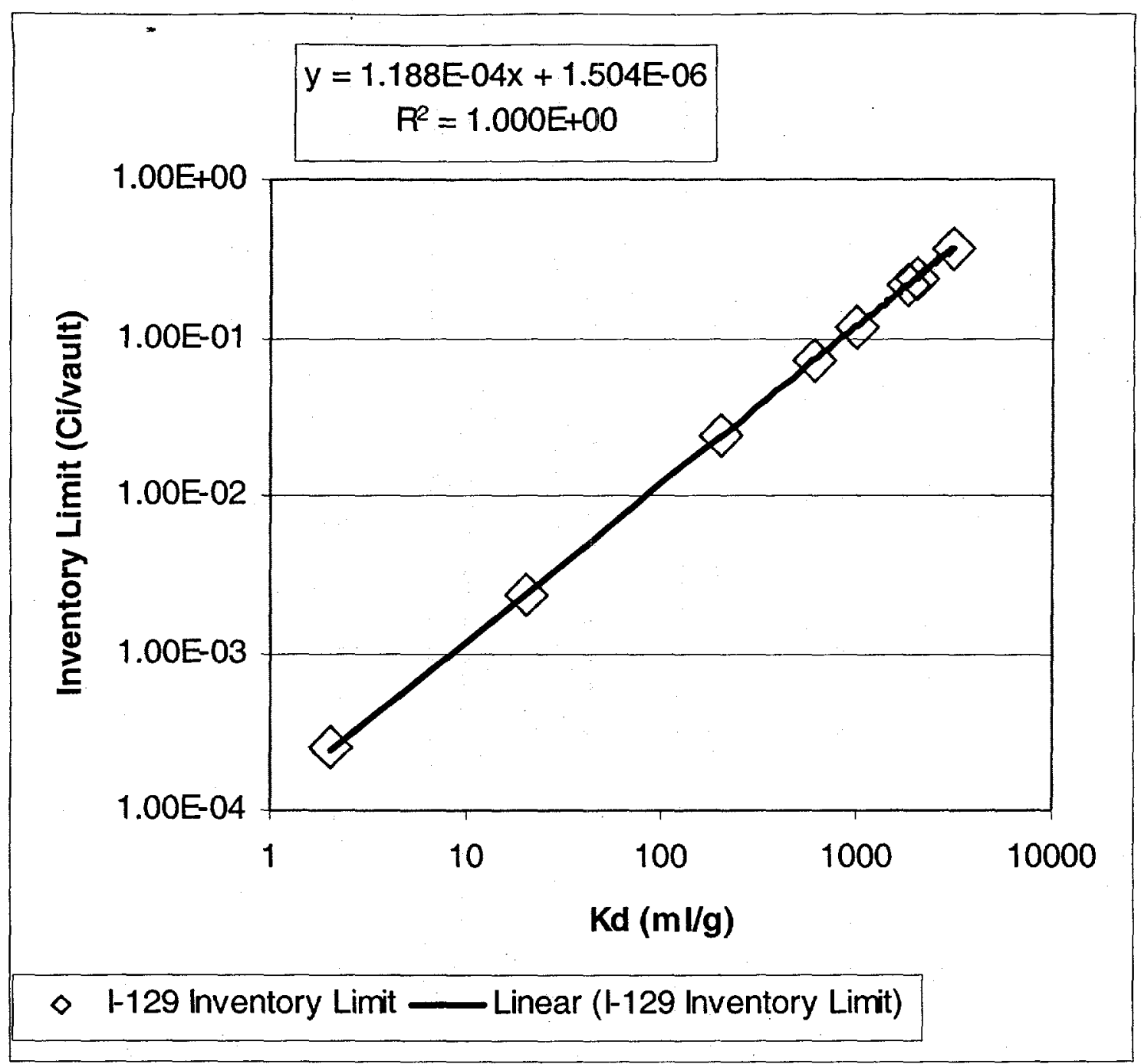

Figure 5.1-1 Inventory Limits as a Function of $K_{d}$ 
SECTION 6

INADVERTENT INTRUDER ANALYSIS

Rev. 1

July 31,2000 
THIS PAGE INTENTIONALLY LEFT BLANK

Rev. 1

July 31,2000 


\section{INADVERTENT INTRUDER ANALYSIS}

Section 6 is identical to Section 6 in the PA revision (WSRC 2000) until Section 6.3.1, where the dose analyses commence, with minor distinctions. The distinctions are as follows:

- the only disposal unit considered is the $\mathbb{I L}$ Vault

- the only radionuclide of interest is I- 129 .

\subsubsection{General Dose Analysis for Agriculture Scenario}

Application of the models in Equations 6.3-1 through 6.3-5 to the IL Vaults produced the results of the dose analysis for the intruder-agriculture scenario.

\subsubsection{Analysis of Intermediate-Level Vaults}

Because of the design of the IL vaults, the agriculture scenario involving direct excavation into the waste is not expected to become credible until long after disposal. Because the waste will be located well below the ground surface, a considerable amount of erosion will need to occur before the waste could be accessed by normal excavation procedures for a home. Then, the concrete roof and layer of uncontaminated grout above the waste are expected to preclude excavation into the waste for as long as they maintain their physical integrity. The assumed performance of the three barriers to excavation into waste is discussed below.

The current closure concept for the IL vaults calls for an earthen cover above the concrete roof of thickness about $3 \mathrm{~m}$ (Sect. 3.2). From data provided in Sect. 3.1.4.1, the average erosion rate for cropland near the SRS is about $2 \mathrm{~kg} / \mathrm{m}^{2}$ - yr, or $1.4 \mathrm{~mm} / \mathrm{yr}$ assuming a reasonable average bulk density of cover soils of $1400 \mathrm{~kg} / \mathrm{m}^{3}$. This erosion rate probably is an upper-bound estimate for the earthen cover, because an estimated erosion rate for natural successional forests (see Sect. 3.1.4.1) is about $0.003 \mathrm{~mm} / \mathrm{yr}$. Excavation for a home normally is assumed to extend no more than about $3 \mathrm{~m}$ below the ground surface (NRC 1981; Oztunali and Roles 1986). The total thickness of the concrete roof and layer of uncontaminated grout above the waste in the IL vaults is expected to be about $1.7 \mathrm{~m}$ (see Sect. 3.2); therefore, at least $2.7 \mathrm{~m}$ of the earthen cover would need to erode before a significant thickness of the waste (about $1 \mathrm{~m}$ ) would be accessible during excavation, such that significant exposures according to the agriculture scenario could occur. Using the estimated erosion rates given above, the time required for $2.7 \mathrm{~m}$ of cover material to erode is estimated to be about 2,000 years and perhaps as long as 900,000 years. The very low erosion rate for natural successional forests is difficult to justify for such a long time. However, a gravel layer about $0.9 \mathrm{~m}$ below the surface in the current closure concept undoubtedly would inhibit further erosion once the gravel layer is exposed. Therefore, erosion to a depth necessary to permit normal excavation into the waste presumably will not occur for at least several thousand years after disposal.

The models for degradation of the concrete roof are described in Section 4.1.3.1 and Appendix D of the PA revision (WSRC 2000). As indicated in Table 4.1-3 of the PA revision, the roof above an IL vault is expected to maintain its integrity for about 1,000 years after disposal, and collapse of the roof is expected to occur at about that time. If the roof were in the form of rubble after collapse, which probably represents a worst-case scenario, excavation through the collapsed roof could occur at that time. 
After the concrete roof over an IL vault fails, the layer of uncontaminated grout above the waste presumably must weather almost entirely to soil-equivalent material before excavation into the waste would become credible. To estimate the weathering rate of grout, this material is assumed to resemble carbonate rock (e.g., limestone) in its weathering properties. Available data summarized by Ketelle and Huff (1984) indicate that the weathering rate of carbonate rock in regions near the SRS is in the range 35 to $100 \mathrm{~mm}$ per 1,000 years. For purposes of this analysis, a weathering rate for the layer of uncontaminated grout of $100 \mathrm{~mm}(0.1 \mathrm{~m})$ per 1,000 years is assumed. This value applies to the expected infiltration rate of water in native soil of $40 \mathrm{~cm} / \mathrm{yr}$ (see Appendix B.1.1) and, thus, applies at times after the concrete roof has failed at about 1,000 years after disposal. A weathering rate at the upper end of the range of reported values for carbonate rock is chosen, because grout should have a somewhat higher porosity than average carbonate rock and correspondingly be more susceptible to weathering by infiltrating water.

The nominal thickness of the uncontaminated grout layer above the waste in the $\mathbb{L}$ vaults is $3 \mathrm{ft}$ $(90 \mathrm{~cm})$. Dividing the thickness of the grout by the weathering rate of $100 \mathrm{~mm}$ per 1,000 years leads to an estimate of 9,000 years. This estimate is based on the assumption that essentially all the grout layer must weather to soil-equivalent material before excavation into waste becomes credible. This estimate shows that even in the absence of a concrete roof, the layer of uncontaminated grout above the waste should prevent excavation into the waste for many thousands of years after disposal.

The analysis described above assumes that excavation into the waste could occur as soon as the concrete roof has failed and the layer of uncontaminated grout above the waste has weathered to soil-equivalent material. This assumption probably is conservative because the space between waste packages in the IL vaults will be backfilled with grout, and the top layer (about $1 \mathrm{~m}$ ) of this grout presumably must weather to soil-equivalent material before significant excavation into the waste could occur. The weathering rate of this material presumably would be about the same as for the grout layer above the waste described above. Therefore, about 10,000 years presumably would be required for a $1-\mathrm{m}$ thick layer of grouted waste to weather to soil-equivalent material. This time is in addition to the time required for weathering of the grout above the waste.

In summary, the concrete roof above the vaults, the layer of uncontaminated grout above the waste, and the grouting of the waste are expected to be effective barriers to excavation into the waste for many thousands of years after disposal. An analysis of the expected performance of the earthen cover above the $I L$ vaults, the concrete roof and the grout layers in the vaults indicates that excavation into the waste probably is not credible for at least 20,000 years after disposal. The gravel layer in the earthen cover, which will be placed about $3.5 \mathrm{~m}$ above the waste, presumably will be quite erosion-resistant, and a typical excavation to a depth of about $3 \mathrm{~m}$ below the gravel surface would not access waste. Even if the gravel layer were subject to the same erosion rate as native soil, the time required for a sufficient thickness of the cover to erode so that about $1 \mathrm{~m}$ of waste would be accessible by excavation should be at least several thousand years and could approach one million years if the current erosion rate for natural successional forests at the SRS is sustained.

From the analysis of the earthen cover and engineered barriers for the $\mathrm{IL}$ vaults presented above, it is clear that the intruder-agriculture scenario is not credible for well beyond 1,000 years. Furthermore, only long-lived radionuclides in the waste possibly could be of concern in an 
analysis of the agriculture scenario for inadvertent intruders. In this analysis, results are presented for 20,000 years after disposal, which is the earliest time that the engineered barriers are expected to have failed sufficiently to permit excavation into a layer of waste about $1-\mathrm{m}$ thick.

The results of the dose analysis for the agriculture scenario are given in Table 6.3-1. The results were calculated using Equations 6.3-4 and 6.3-5. The scenario dose conversion factors (SDCFs) for the long-lived radionuclides of concern are given in Table 6.3-1 of the PA revision. The SDCF is the EDE divided by the concentration of interest. The geometrical reduction factor for the $\mathbb{I}$ vaults is 0.4 . The fraction of the initial inventory of radionuclides remaining in the vaults at the various times after disposal, which takes into account radioactive decay and mobilization and transport in water, was calculated using the PORFLOW computer code.

Table 6.3-1 Intruder-based I-129 disposal limits for IL vaults - agriculture scenario at 20,000 years

\begin{tabular}{lccccc}
\hline & $\begin{array}{c}\mathrm{Kd} \\
\mathrm{ml} / \mathrm{g}\end{array}$ & $\begin{array}{c}\text { Time of } \\
\text { Assessment } \\
(\mathrm{yr})\end{array}$ & $\begin{array}{c}\text { Fraction } \\
\text { Remaining }^{\mathrm{a}}\end{array}$ & $\begin{array}{c}\text { Concentration } \\
\text { Limit }^{\mathrm{b}} \\
\left(\mu \mathrm{Ci} / \mathrm{m}^{3}\right)\end{array}$ & $\begin{array}{c}\text { Inventory } \\
\text { Limit }^{\mathrm{c}} \\
(\mathrm{Ci} / \mathrm{vault})\end{array}$ \\
\hline Waste Form & 600 & 20,000 & 0.502 & 6000 & 34 \\
\hline Activated Carbon & 600 & Used conservative & 10,000 year inventory to lessen computer simulation time & \\
b Limit on average concentration in disposed waste; obtained from Eq. 6.3-5 & \\
c Limit on inventory per vault; obtained from Eq. 6.3-4, assuming a vault volume of $5.7 \mathrm{E} 3 \mathrm{~m}^{3}$.
\end{tabular}

The results of the analysis are given in two forms, both of which are based on the dose limit for inadvertent intruders of 100 mrem per year. The first set of results is in the form of limits on average concentrations of radionuclides in the waste. The second set of results is in the form of limits on total activity of radionuclides in each vault.

The results in Table 6.3-1 may be interpreted as follows. The maximum dose would occur at the time after disposal at which the agriculture scenario first becomes credible, and the results at 20,000 years represent lower-bound estimates of limits on average concentrations and inventories of radionuclides in waste.

\subsubsection{General Dose Analysis for Resident Scenario}

Two bounding assumptions have been used in the dose analysis for the resident scenario for inadvertent intruders. In the first case, the intruder is assumed to reside in a home located immediately on top of an intact concrete roof or other engineered barrier above a disposal unit, and the scenario is assumed to be credible immediately following loss of active institutional control at 100 years after disposal. In the second case, the home is assumed to be located immediately on top of the waste in a disposal unit, but the scenario is assumed not to occur until the concrete roof and any other engineered barriers above the waste have lost their integrity and can be penetrated during excavation.

In both bounding cases for the resident scenario, the intruder is assumed not to excavate into the waste itself while constructing a home on the disposal site. Thus, the only exposure pathway of 
concern for this scenario is external exposure to photon-emitting radionuclides in the waste while residing in the home. The only differences between the two bounding cases are the time at which the scenario is assumed to become credible, as described above, and the amount of shielding between the source region (i.e., the waste) and the receptor location.

The resident scenario is potentially relevant at any time following the 100 -year institutional control period until the agriculture scenario becomes credible. Once the agriculture scenario becomes credible, the resident exposure becomes irrelevant because the agriculture scenario includes the resident scenario.

The SDCFs obtained from the model for estimating dose to an inadvertent intruder for the resident scenario are summarized in Table 6.3-2 in the PA revision (WSRC 2000). For all units, the geometrical reduction factors are listed in Table 6.3-4 in the PA revision (WSRC 2000). The remainder of this section discusses application of the model represented by Equations 6.3-4 and 6.3-5 to the IL Vaults in E Area.

\subsubsection{Analysis of Intermediate-Level Vaults}

As described previously, the IL vaults will be constructed with a concrete roof of average thickness about $90 \mathrm{~cm}$ and a layer of uncontaminated grout above the waste of thickness about 90 $\mathrm{cm}$. Thus, the total thickness of these engineered barriers is about $1.8 \mathrm{~m}$, and this thickness of shielding would apply to the resident scenario for the $\mathbb{I L}$ vaults at 100 years after disposal when all engineered barriers are assumed to be intact and impenetrable by normal excavation procedures.

As described in Appendix B.3.3, the $1.8 \mathrm{~m}$ thickness of shielding in the $\mathbb{L}$ vaults is sufficient to reduce the external dose to very low levels for any conceivable concentrations of photon-emitting radionuclides in the waste. Therefore, in the dose analysis for the $\mathbb{L}$ vaults at 100 years after disposal, the conservative assumption is made that only the layer of uncontaminated grout above the waste is present to provide shielding. For purposes of this analysis, the thickness of the grout layer is assumed to be $100 \mathrm{~cm}$. This value is slightly greater than the planned thickness and is intended to take into account the somewhat greater shielding provided by any metal waste containers and waste forms in the IL vaults compared with the shielding provided by soilequivalent material.

The results of the dose analysis for the resident scenario at 100 years after disposal are given in Table 6.3-2. The results are calculated in the same manner as those for the agriculture scenario using Eqs. 6.3-4 and 6.3-5, and the SDCFs are those for $100 \mathrm{~cm}$ of shielding in Table 6.3-2 of the PA revision. The fraction remaining was calculated using PORFLOW. The geometrical reduction factor of 0.4 was assumed (Table 6.3-4 of the PA revision).

The results in Table 6.3-3 are expected to be quite pessimistic, and thus, the derived concentration and inventory limits are identified as worst-case conditions. As described above, the assumed thickness of shielding of $100 \mathrm{~cm}$ for these calculations greatly underestimates the amount of shielding that would be provided by an intact concrete roof and the uncontaminated layer of grout above the waste. 
Table 6.3-2 Intruder-based I-129 disposal limits for IL vaults - resident scenario at 100 years

\begin{tabular}{lccccc}
\hline Waste Form & $\begin{array}{c}\mathrm{Kd} \\
\mathrm{ml} / \mathrm{g}\end{array}$ & $\begin{array}{c}\text { Time of } \\
\text { Assessment } \\
(\mathrm{yr})\end{array}$ & $\begin{array}{c}\text { Fraction } \\
\text { Remaining }\end{array}$ & $\begin{array}{c}\text { Concentration } \\
\text { Limit }^{\mathrm{a}} \\
\left(\mu \mathrm{Ci} / \mathrm{m}^{3}\right)\end{array}$ & $\begin{array}{c}\text { Inventory Limit } \\
(\mathrm{Ci} / \mathrm{vault})\end{array}$ \\
\hline Activated Carbon & 600 & 100 & $1.0 \mathrm{E}+00$ & $\mathrm{c}$ & $\mathrm{c}$ \\
\hline a & Limit on average concentration in disposed waste; obtained from Eq. $6.3-5$ &. \\
b & Limit on inventory per vault; obtained from Eq. 6.3-4, assuming a vault volume of $5.7 \mathrm{E} 4 \mathrm{~m}^{3}$. \\
c & EDE negligible with the $100 \mathrm{~cm}$ shielding of intact vault.
\end{tabular}

As described previously, the second bounding case for the resident scenario for the $\mathrm{IL}$ vaults is based on the assumption that the intruder's home is located immediately on top of exposed waste in a disposal unit, but that the excavation for the home does not penetrate into the waste itself, because the grout at the depth of the top layer of waste is still intact. Therefore, this variation of the resident scenario could not reasonably occur until the concrete roof above the vaults has lost its integrity and the layer of uncontaminated grout above the waste has weathered to soilequivalent material. An analysis described previously in presenting the results for the agriculture scenario indicates that the earliest the second bounding case for the resident scenario could occur is about 10,000 years after disposal.

The results of the dose analysis for the resident scenario at 10,000 years after disposal are given in Table 6.3-3 and again are obtained using Equations 6.3-4 and 6.3-5. The SDCFs in this case are those for no shielding in Table 6.3-2 of the PA revision. Only long-lived radionuclides are of concern at this time.

Table 6.3-3 Intruder-based I-129 disposal limits for IL vaults - resident scenario at 10,000 years

\begin{tabular}{cccccc}
\hline Waste Form & $\begin{array}{c}\mathrm{Kd} \\
\mathrm{ml} / \mathrm{g}\end{array}$ & $\begin{array}{c}\text { Time of } \\
\text { Assessment } \\
(\mathrm{yr})\end{array}$ & $\begin{array}{c}\text { Fraction } \\
\text { Remaining }\end{array}$ & $\begin{array}{c}\text { Concentration Limit } \\
\left(\mu \mathrm{Ci} / \mathrm{m}^{3}\right)\end{array}$ & $\begin{array}{c}\text { Inventory Limit }^{\mathrm{b}} \\
\left(\mathrm{Ci} / \mathrm{vault}^{\mathrm{m}}\right)\end{array}$ \\
\hline Activated Carbon & 600 & 10,000 & $1.0 \mathrm{E}+00$ & $1.8 \mathrm{ES}$ & 1,000 \\
\hline
\end{tabular}

${ }^{2}$ Limit on average concentration in disposed waste; obtained from Eq. 6.3-5

${ }^{b}$ Limit on inventory per vault; obtained from Eq. $6.3-4$, assuming a vault volume of $5.7 \mathrm{E} 4 \mathrm{~m}^{3}$.

The assumption that residence on top of exposed waste could occur at 10,000 years after disposal may also be pessimistic for the IL vaults. Even if the gravel layer were exposed by this time, it presumably would be quite resistant to further erosion. Because the top of the gravel layer will be about $3.5 \mathrm{~m}$ above the top layer of waste and an excavation for a home is assumed to extend no more than $3 \mathrm{~m}$ below the ground surface, an excavation at 10,000 years probably would not extend to the depth of waste. The additional shielding provided by the remaining layer of uncontaminated material between the bottom of the excavation and the waste has not been taken into account in the dose analysis. 
In contrast to the dose analysis for the agriculture scenario, there is no need to perform a dose analysis for the resident scenario at times after residence on top of exposed waste first becomes credible. At later times the top layer of waste presumably would begin to weather to soilequivalent material and the agriculture scenario, which always results in a higher dose per unit concentration of radionuclides, then becomes the scenario of concern.

\subsubsection{Dose Analysis for Post-Drilling Scenario}

The post-drilling scenario is potentially relevant for any disposal units for which drilling into the waste may occur before the agriculture scenario becomes credible. In the $\mathrm{IL}$ vaults, the waste will be grouted, and drilling into the waste is not expected to be a credible occurrence until the grout essentially has weathered to soil-equivalent material, at which time the agriculture scenario becomes credible. Because the agriculture scenario always results in more restrictive disposal limits for radionuclides than the post-drilling scenario for the same time, the post-drilling scenario need not be considered further in the IL vaults.

\subsection{Sensitivity and Uncertainty in Dose Models for Inadvertent Intruders}

The sensitivity and uncertainty analysis for the $\mathbb{L}$ Vaults is similar to that in the PA revision (WSRC 2000). The PA revision focused on six parameters. Those parameters and the factors of uncertainty for each of them are as follows:

\section{Parameter}

Atmospheric mass loading of

contaminated surface soil

Consumption of contaminated soil

Exposure time for working in a garden

Exposure time for residing in a home

Fractions of initial radionuclide inventory

remaining in the waste

Plant-to-soil concentration factors

\author{
Factors of Uncertainty \\ Not applicable \\ 1 order of magnitude \\ 3 \\ 2 \\ For high $\mathrm{Kd}$ contaminants this is primarily a \\ function of radioactive decay, so very little \\ uncertainty \\ 1 to 3 orders of magnitude.
}

The major difference between the PA revision (WSRC 2000) and this report is that this report only considers I-129 with varying $\mathrm{K}_{d} \mathrm{~s}$. The most important factor in determining whether or not the WAC derived from dose analyses for inadvertent intruders are likely to be reasonable is the credibility of the assumed exposure scenarios, i.e., whether the assumed exposure scenarios reasonably could occur at a particular disposal facility, rather than any estimates of uncertainties in the results due to uncertainties in model parameters. 


\section{SECTION 7}

PERFORMANCE EVALUATION

Rev. 1

July 31,2000 
THIS PAGE INTENTIONALLY LEFT BLANK

Rev. 1

July 31,2000 


\section{Performance evaluation}

The purpose of this waste-specific SA of the E-Area LLWF is to fulfill the DOE Order 435.1 requirement that such an assessment be prepared and maintained for any LLW disposal facility located at a DOE field site. In this chapter of the SA, a comparison of the SA results to DOE Order is provided and the utility of the results in developing operational limits is discussed. Ongoing or planned investigations that are needed in support of the SA process are also discussed.

\subsection{Comparison of Results to Performance Objectives and Requirements}

The performance objectives and assessment requirements of DOE Order 435.1 for LLW disposal are listed in Section 2.5. In essence these objectives put forth dose limits for members of the public that are not to be exceeded through consideration of credible pathways. The requirements establish that impacts on water resources and inadvertent intruders are to be assessed.

For the groundwater impacts requirement, it has been determined that compliance with current, not proposed, EPA standards is required because of the interpretation of CERCLA regulations by the State of South Carolina. However, if and when EPA changes those standards, the inventory limits presented in this report must be recalculated.

To evaluate the performance of the E-Area LLWF with respect to protection of the public from releases to water, soil, plants, and animals and with respect to impacts on water resources, groundwater concentrations were estimated for a uniformly loaded vault and compared with the more restrictive of either allowable groundwater concentrations based on a $25 \mathrm{mrem} / \mathrm{yr}$ dose (the performance objective for protection of off-site members of the public from radionuclides released to any media but the atmosphere) or MCLs (the performance measure for impacts on water resources). Based on this comparison, inventory limits for the $\mathbb{L}$ Vaults for wasteforms with high concentrations of I-129 were developed as a function of $K_{d}$ (Section 5.1). Inventory limits resulting from atmospheric releases of radionuclides were determined to be inconsequential (Section 4.1.2). For inadvertent intruders, inventory limits were calculated and presented in Section 6, based on a comparison of estimated doses to intruders with the $100 \mathrm{mrem} / \mathrm{yr}$ limit on EDE for continuous exposure. The I-129 limit for the activated carbon wasteform in the ILV is 0.0714 curies per vault.

In this section, the calculated inventory limit for the activated carbon wasteform is compared to the projected inventory for this wasteform. The result of the comparison is presented in Table 7.1-1.

The inventory limit for a single IL Vault is presented in the second column of this table. It is the lowest limit calculated after consideration of all intruder scenarios, groundwater pathways, and air pathways for up to 10,000 years after closure of the facility. The third column identifies the limiting pathway, the intruder scenario, or groundwater or air pathway that provides this lowest limit. The fourth column lists the projected inventory of each waste form (from Appendix A) for the existing IL Vault. Finally, the fifth column in the table is the ratio of the inventory limit to the projected inventory. 
Table 7.1-1 IL Vaults: High-Concentration I-129 Waste Inventory Limit, Limiting Pathway, and Comparison to Projected Inventory

\begin{tabular}{|c|c|c|c|c|}
\hline Waste Form & $\begin{array}{l}\text { Inventory limit }{ }^{a} \\
\text { Ci per vault }\end{array}$ & $\begin{array}{l}\text { Limiting } \\
\text { pathway }\end{array}$ & $\begin{array}{c}\text { Projected inventory } \\
\text { for one } \mathrm{IL} \mathrm{Vault} \\
\text { Total Ci }\end{array}$ & $\begin{array}{l}\text { Ratio of inventory limit } \\
\text { to projected inventory }\end{array}$ \\
\hline Activated Carbon & $7.14 \mathrm{E}-2$ & gw & $7.30 \mathrm{E}-2$ & 0.98 \\
\hline \multicolumn{5}{|c|}{$\begin{array}{l}\text { Inventory limit based on consideration of peak groundwater concentration outside } 100 \text {-m buffer } \\
\text { zone around disposal units (Section 5) and inadvertent intruder doses (Section 6). } \\
\text { Identifies whether intruder scenario, groundwater ingestion pathway ("gw"), or air pathway is } \\
\text { most restrictive with respect to developing inventory limits. } \\
\text { A ratio that is one or greater indicates that the projected inventory is less than the estimated } \\
\text { inventory limit. }\end{array}$} \\
\hline
\end{tabular}

For the activated carbon wasteform, the calculated inventory limit is slightly smaller than the projected inventory. Thus, at present, not all the projected inventory can be accepted for disposal. However, the projected inventories are highly uncertain. The actual future inventory may be less than the projected inventory for two reasons as follows:

1. Future site activities may diminish, thus reducing the amount of waste generated.

2. On average, I-129 concentrations for future activated carbon vessels may be less than the concentration used for projections. Activated carbon vessels already in the IL Vault have an average I-129 content of $4.8 \mathrm{E}-4 \mathrm{Ci}$ per vessel. Vessel \#9, awaiting disposal, was characterized at $7.11 \mathrm{E}-3 \mathrm{Ci}$. The higher value was used as an estimate for all future vessels. The projected inventory using a weighted average of the five vessels would be $2.53 \mathrm{E}-2 \mathrm{Ci}$ versus the Table $7.1-1$ value of $7.30 \mathrm{E}-2 \mathrm{Ci}$.

Even if the actual future inventory exceeds the inventory limit for the existing IL Vault, mitigating measures are available. Waste could be stored until the second $\mathbb{I L}$ Vault is constructed. Waste could be repackaged and sent to the LAW vault, because the Activated Carbon Vessels are not true intermediate-level waste; only the configuration (i.e., size and weight) of the waste prevents its direct disposal in the LAW vault. Alternatively, waste could be disposed off-site.

\subsection{Use of Special Analysis Results}

The information in this section is identical to that in Section 7.3 of the PA revision (WSRC 2000). A special addition in this report is an equation developed to help estimate the inventory limits for high-concentration I-129 waste forms that may have $\mathrm{K}_{\mathrm{d}} \mathrm{s}$ measured in the future. That equation was presented and discussed in Section 5.1 and is as follows:

$$
\text { Inventory Limit }(\mathrm{Ci} / \mathrm{vault})=1.188 \mathrm{E}-4 * \mathrm{~K}_{\mathrm{d}}(\mathrm{ml} / \mathrm{g})+1.504 \mathrm{E}-6 \text {. }
$$

This equation allows inventory limits and ultimately WAC to be developed for different future high-concentration wasteforms without requiring a new or revised SA.

\subsection{Further Work}

The information in this section is identical to that in Section 7.4 of the PA revision (WSRC 2000). 
SECTION 8

QUALITY ASSURANCE

Rev. 1

July 31,2000 
THIS PAGE INTENTIONALLY LEFT BLANK

Rev. 1

July 31,2000 


\section{QUALITY ASSURANCE}

The information in this section is identical to that in Section 8 of the PA revision (WSRC 2000). 
THIS PAGE INTENTIONALLY LEFT BLANK

Rev. 1 
SECTION 9

LIST OF PREPARERS

Rev. 1

July 31,2000 


\section{LIST OF PREPARERS}

Collard, Leonard B.

M.S. Civil Engineering - University of Arizona

B.A. Duke University - Mathematics and Economics

Experience: Mr. Collard has over 15 years of experience in subsurface flow and contaminant transport modeling. He has over 20 years of experience in modeling. He worked for over 11 years at Hanford before coming to SRS. His contributions at SRS have supported Solid Waste, working on the Performance Assessment, Composite Analysis and Special Analyses and have supported High-Level Waste, developing a three-dimensional flow and transport model. 
THIS PAGE INTENTIONALLY LEFT BLANK

Rev. 1 
SECTION 10

\section{REFERENCES}

Rev. 1 
THIS PAGE INTENTIONALLY LEFT BLANK

Rev. 1

July 31,2000 


\section{0. - REFERENCES}

The references cited in this report are listed Section 10 of the PA revision (WSRC 2000), except that additional references and newer revisions are added as follows:

Kaplan, D.I., S.M. Serkiz, and N.C. Bell. 1999. 1-129 Desorption from SRS Water Treatment Media from the Effluent Treatment Facility and the F-Area Groundwater Treatment Facility, WSRCTR-99-270, Westinghouse Savannah River Company, Aiken, South Carolina.

Liam, K.C., S.K. Roy, and D.O. Northwood. 1992. Chloride Ingress Measurements and Corrosion Potential Mapping Study of a 24-Year-Old Reinforced-Concrete Jetty Structure in a Tropical Marine-Environment, Magazine of Concrete Research, V44, N160 (Sep), ISSN: 0024-9831, pp. 205-215.

WSRC. 1999a. Safety Analysis Report Savannah River Site Solid Waste Management Facility (U), WSRC-SA-22, Rev.2, September 1999.

WSRC. 1999b. WSRC 1S Savannah River Site Waste Acceptance Criteria Manual, Procedure WAC 3.17 Low Level Radioactive Waste Acceptance Criteria, Rev. 2 (U), June 1999.

WSRC. 2000. Radiological Performance Assessment for the E-Area Low-Level Waste Facility, WSRC-RP-94-218, Rev.1, January 31, 2000. 
THIS PAGE INTENTIONALLY LEFT BLANK

Rev. 1

July 31,2000 
APPENDIX A

PROJECTED INVENTORY FOR HIGH-CONCENTRATION I-129 WASTE 
THIS PAGE INTENTIONALLY LEFT BLANK

Rev. 1 
The I-129 inventory projected over ten years for activated carbon vessels from the Effluent Treatment Facility is shown in Table A.1.

Table A.1 Projected Inventory for High-Concentration I-129 Waste Considered for Disposal in the IL Vaults

\begin{tabular}{ll}
\hline \multicolumn{1}{c}{ Waste Form } & Projected Inventory $(\mathrm{Ci})^{\mathrm{a}}$ \\
\hline Existing Activated Carbon Vessels in IL Vault & $1.92 \mathrm{E}-3$ \\
Future Activated Carbon Vessels & $7.11 \mathrm{E}-2$ \\
Total in Activated Carbon Vessels & $7.30 \mathrm{E}-2$ \\
\hline
\end{tabular}

${ }^{a}$ Walliser, 1999.

\section{REFERENCE}

Walliser, S.A., Interoffice Memo SWD-ETF-99-078, December, 1999 - attached. 
OSR 31-688 (Rev 11-20-97)

Stores. $26-8910.00$

\section{WESTINGHOUSE SAVANNAH RIVER COMPANY INTEROFFICE MEMORANDUM}
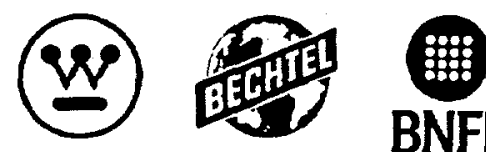

BNFL

SWD-ETF-99-078

December 15, 1999

Leonard Collard, 773-43A

Waste Disposal and Env. Develop

From: $\quad$ S.A. Walliser, 704-23H, 8-1862

ETF Facility Support

Subject: Projections of Resin and Carbon Wastes

The purpose of this memo is to formalize the projections of both GT-73 resin and activated carbon wastes which were contained in various email messages.

\section{Activated Carbon}

Carbon vessel \#9 was sampled in January, 1998, for radionuclides for the purpose of revising/upgrading the carbon waste stream characterization. The I-129 concentration was reported as $301 \mathrm{pCi} / \mathrm{g}$, resulting in an I-129 loading of 7.11E-03 Ci for the vessel. The details of this calculation are shown in Attachment 1.

The annual low level waste forecast for ETF has projected one spent carbon vessel per year. This results in a ten year inventory projection of 7.11E-02 Ci I-129. See Attachment 3.

\section{Organic Removal System GT-73 Resin}

The Organic Removal System, Mercury Removal Column \#2, GT-73 resin was sampled July, 1998 , for radionuclides for the purpose of upgrading the GT-73 resin waste stream characterization. The I-129 concentration was initially reported as $0.0483 \mathrm{pCi} / \mathrm{g}$ (GEL Lab lower limit of detection value); however, subsequent reanalysis indicated $36.3 \mathrm{pCi} / \mathrm{g}$ (SRT-ADS-991227). Using the SRTC value, this correlates to $3.71 \mathrm{E}-05 \mathrm{Ci}$ I-129 per vessel. The sample results and calculations are shown in Attachment 2.

The low level waste forecast for ETF has projected three OR GT-73 vessel volumes every two year. This results in a ten year inventory projection of 5.57E-04 Ci I-129. See Attachment 3.

\section{Ion Exchange System GT-73 Resin}

The Ion Exchange GT-73 resin columns were not sampled up through 1998. Based on the configuration of the ETF process systems, ETF Engineering estimated that the IX GT-73 resin 
would only be subject to about $1 / 10^{\text {th }}$ of the I-129 adsorbed by the carbon. Thus, the IX GT-73 I129 concentration was estimated to be $3.6 \mathrm{pCi} / \mathrm{g}$. This estimation has been subsequently confirmed with more recent sampling and analysis (see Attachment 2, Footnote \#1). The 3.6 $\mathrm{pCi} / \mathrm{g}$ concentration correlates to $5.77 \mathrm{E}-06 \mathrm{Ci} \mathrm{I}-129$ per vessel.

The low level waste forecast for ETF included two IX GT-73 vessel volumes every two years. This results in a ten year inventory projection of 5.77E-05 Ci I-129. See Attachment 3. 
Should-you have any questions, please advise.

\section{Attachments}

Cc: $\quad$ N. Roddy

D. Sink

S. Wiggins

T. Lookabill

M. Birk

D. Collins

L. Rykken

T. Butcher

ETF Files

Rev. 1 
SWD-ETF-99-078

December 10, 1999

Page 3 of 5

\section{Attachment 1}

ETF Carbon Vessel \#9

Sampled: Jan 1998, SRS Site Sample Management Id 98037-1

\begin{tabular}{|l|c|c|}
\hline Nuclide & $\begin{array}{c}\text { Sample Results } \\
\text { (pCi/g) }\end{array}$ & $\begin{array}{c}\text { Calculated } \\
\text { (Ci/vessel) }\end{array}$ \\
\hline $\mathrm{H}-3$ & 1690 & $3.99 \mathrm{E}-02$ \\
\hline $\mathrm{C}-14$ & 24.7 & $5.83 \mathrm{E}-04$ \\
\hline $\mathrm{Ni}-59$ & 11.5 & $2.71 \mathrm{E}-04$ \\
\hline $\mathrm{Tc}-99$ & 21.3 & $5.03 \mathrm{E}-04$ \\
\hline $\mathrm{l}-129$ & 301 & $7.11 \mathrm{E}-03$ \\
\hline $\mathrm{Cs}-137$ & 45.9 & $1.08 \mathrm{E}-03$ \\
\hline $\mathrm{Ba}-137 \mathrm{~m}$ & 43.4 & $1.02 \mathrm{E}-03$ \\
\hline $\mathrm{U}-233 / 234$ & 1.57 & $3.71 \mathrm{E}-05$ \\
\hline $\mathrm{Np}-237$ & 4.03 & $9.51 \mathrm{E}-05$ \\
\hline $\mathrm{Pu}-239 / 240$ & 86 & $2.03 \mathrm{E}-03$ \\
\hline Am-241 & 14.8 & $3.49 \mathrm{E}-04$ \\
\hline $\mathrm{U}-238$ & 2.98 & $7.04 \mathrm{E}-05$ \\
\hline $\mathrm{Pu}-238$ & 177 & $4.18 \mathrm{E}-03$ \\
\hline $\mathrm{Pu}-241$ & 239 & $5.64 \mathrm{E}-03$ \\
\hline $\mathrm{Pu}-242$ & 1.57 & $3.71 \mathrm{E}-05$ \\
\hline $\mathrm{Co}-60$ & 4.21 & $9.94 \mathrm{E}-05$ \\
\hline $\mathrm{Sr}-90$ & 11.8 & $2.79 \mathrm{E}-04$ \\
\hline & & $6.33 \mathrm{E}-02$ \\
\hline
\end{tabular}

Conversion Factors:

$454 \mathrm{~g} / \mathrm{lb}$

$1.00 \mathrm{E}+12 \mathrm{pCi} / \mathrm{Ci}$

\section{Carbon Vessel Weights:}

70,000 lbs gross wt typical

$18,000 \mathrm{lbs}$ tare wt

52,000 lbs waste wt

Waste weight content consists of spent carbon, adsorbed organics, biological growth, and moisture.

Calculated by: S. A. Walliser, $6 / 1 / 99$

For the purposes of waste forecasting and disposal, a carbon vessel is manifested as $1032 \mathrm{ft} 3$. 
SWD-ETF-99-078

December 10, 1999

Page 4 of 5

\section{Attachment 2}

ETF Organic Removal (OR), Mercury Removal Column \#2 (GT-73 Resin)

Sampled: July 1998 (Documented in SWD-ETF-99-005)

And Estimated Ion Exchange (IX), Mercury Removal Column Radionuclides

\begin{tabular}{|c|c|c|c|c|}
\hline Nuclide & $\begin{array}{l}\text { Adjusted OR } \\
\text { Sample Result } \\
\text { (pCi/g) }\end{array}$ & $\begin{array}{l}\text { OR Spent } \\
\text { Resin } \\
\text { (Ci/ft3) }\end{array}$ & $\begin{array}{l}\text { Calculated } \\
\text { OR Hg Col } \\
\text { (Ci/vessel) }\end{array}$ & $\begin{array}{l}{ }^{2} \text { Estimated } \\
\text { IX Hg Col } \\
\text { (Ci/vessel) }\end{array}$ \\
\hline $\mathrm{H}-3$ & 343 & $7.79 \mathrm{E}-06$ & 3.50 E-04 & $5.45 E-04$ \\
\hline C-14 & 33.6 & $7.63 E-07$ & 3.43E-05 & $5.34 \mathrm{E}-05$ \\
\hline $\mathrm{Ni}-59$ & 1.48 & $3.36 \mathrm{E}-08$ & $1.51 \mathrm{E}-06$ & $2.35 E-06$ \\
\hline Co-60 & 195 & 4.43E-06 & $1.99 \mathrm{E}-04$ & $3.10 E-04$ \\
\hline Sr-90 & 2370 & $5.38 \mathrm{E}-05$ & $2.42 E-03$ & 3.77E-03 \\
\hline$Y-90$ & 2370 & $5.38 E-05$ & $2.42 E-03$ & $3.77 E-03$ \\
\hline Tc-99 & 84 & 1.91E-06 & $8.58 E-05$ & 1.33E-04 \\
\hline $1-129$ & $0.0483^{\prime}$ & $1.10 E-09$ & $4.93 E-08$ & $7.67 E-08$ \\
\hline I-129 (reanalysis) & 36.3 & $8.24 E-07$ & 3.71E-05 & 5.77E-06 \\
\hline Cs-137 & 10,100 & $2.29 E-04$ & 1.03E-02 & $1.60 \mathrm{E}-02$ \\
\hline $\mathrm{Ba}-137 \mathrm{~m}$ & 9554.6 & $2.17 E-04$ & $9.76 E-03$ & $1.52 \mathrm{E}-02$ \\
\hline $\mathrm{Np}-237$ & 0.0439 & $9.97 E-10$ & $4.48 \mathrm{E}-08$ & $6.98 \mathrm{E}-08$ \\
\hline Pu-238 & 246 & $5.58 E-06$ & 2.51E-04 & 3.91E-04 \\
\hline Am-241 & 109 & 2.47E-06 & 1.11E-04 & $1.73 \mathrm{E}-04$ \\
\hline $\mathrm{Pu}-241$ & 5020 & $1.14 \mathrm{E}-04$ & $5.13 \mathrm{E}-03$ & $7.98 E-03$ \\
\hline U-233 & 8.84 & $2.01 E-07$ & $9.03 E-06$ & $1.40 E-05$ \\
\hline U-234 & 8.84 & $2.01 \mathrm{E}-07$ & $9.03 E-06$ & $1.40 \mathrm{E}-05$ \\
\hline U-235 & 1.45 & $3.29 E-08$ & 1.48E-06 & $2.30 E-06$ \\
\hline $\mathrm{Pu}-239$ & 1050 & $2.38 \mathrm{E}-05$ & $1.07 \mathrm{E}-03$ & $1.67 \mathrm{E}-03$ \\
\hline & & TOTAL: & 3.22E-02 & 5.00E-02 \\
\hline
\end{tabular}

Conversion Factors:

$454 \mathrm{~g} / \mathrm{lb}$

$1.00 \mathrm{E}+12 \mathrm{pCi} / \mathrm{Ci}$

Resin Density:

$50 \mathrm{lb} / \mathrm{ft} 3$

OR Hg Col Resin Volume:

$45 \mathrm{ft} 3$

IX Hg Col Resin Volume:

$70 \mathrm{ft} 3$

1. IX GT-73 resin $1-129$ concentration is estimated to be $1 / 10^{\text {th }}$ of the OR GT-73 value due to process configuration. Subsequent analysis by SRTC (ADS Id 3-134077) 
SWD-ETF-99-078

December 10, 1999

Page 5.of 5

showed $3.13 \mathrm{pCi} / \mathrm{g}$, thus confirming Engineering's original estimation.

Calculated by S. A. Walliser, 6/2/99, modified 12/14/99

\section{Attachment 3}

ETF Waste Projection Summary

(Based on 1998 sampling data)

\begin{tabular}{|l|c|c|c|}
\hline & Carbon & OR GT-73 & IX GT-73 \\
\hline $\mathrm{I}-129(\mathrm{pCi} / \mathrm{g})$ & 301 & 36.3 & 3.63 \\
\hline Waste Weight or Vol & $52,000 \mathrm{lbs}$ & $45 \mathrm{ft} 3$ & $70 \mathrm{ft} 3$ \\
\hline Curies (I-129) per Vessel & $7.11 \mathrm{E}-03$ & $3.71 \mathrm{E}-05$ & $5.77 \mathrm{E}-06$ \\
\hline Expected Waste Generation Rate & 1 vessel/year & $\begin{array}{c}3 \text { vessel volumes } \\
\text { every two years }\end{array}$ & $\begin{array}{c}2 \text { vessel volumes } \\
\text { every two years }\end{array}$ \\
\hline Ten Year Projection (I-129 Ci) & $7.11 \mathrm{E}-02$ & $5.57 \mathrm{E}-04$ & $5.77 \mathrm{E}-05$ \\
\hline
\end{tabular}

The density of damp GT-73 resin is $50 \mathrm{lb} / \mathrm{ft} 3$ 
THIS PAGE INTENTIONALLY LEFT BLANK

Rev. 1

July 31,2000 


\section{APPENDIX B}

SUPPORTING DETAILS OF MODELS AND ASSUMPTIONS

Rev. 1

July 31,2000 
THIS PAGE INTENTIONALLY LEFT BLANK

Rev. 1 
Appendix B provides details of models and assumptions that support the information provided in Sections 4 through 6 of the main body of this SA.

\section{B.1 VADOSE ZONE MODELS}

Vadose zone models were developed to analyze the release and transport of radionuclides from the waste facility to the aquifer.

\section{B.1.1 Infiltration}

Because Section B.1.1 is independent of the facility, it is identical to Section C.1.1 in the PA revision (WSRC 2000).

\section{B.1.2 Supporting Data for the Conceptual Vadose Zone Model}

This section is identical to Section C.1.2.3 in the PA revision (WSRC 2000).

\section{B.2 SATURATED ZONE MODEL}

Section B.2, discussing the saturated zone model, is identical to Section C. 2 in the PA revision (WSRC 2000).

\section{B.3 INTRUDER MODELS}

Section B.3, discussing intruder models, is identical to Section C.3 in the PA revision (WSRC 2000); except that no screening was performed, only high-concentration $1-129$ wastes were considered, and the results are different. Parameters for the I-129 analysis were extracted from PA revision tables and are presented below. For clarification, $\rho_{\mathrm{s}}$ is the dry bulk density of soil $\left(\mathrm{kg} / \mathrm{m}^{3}\right)$. The overall factor of EDE per unit concentration can be conveniently referred to as the scenario dose conversion factor (SCDF) as shown in Table B.3-16.

Table B.3-1 Radionuclides Considered in Dose Analyses for Off-site Individuals or Inadvertent Intruders

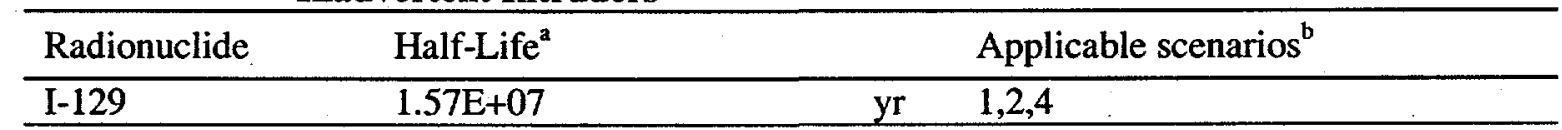

${ }^{a}$ Values from Kocher (1981).

b 1 = groundwater transport pathway, off-site individuals;

2 = agriculture scenario, inadvertent intruders;

$3=$ resident scenario, inadvertent intruders;

$4=$ post-drilling scenario, inadvertent intruders. 
Table B.3-2 Internal Dose Conversion Factors (DCFs) for Ingestion and Inhalation of Radionuclides

\begin{tabular}{lll}
\hline Radionuclide & $\begin{array}{l}\text { Ingestion } \mathrm{DCF}^{\mathrm{a}} \\
\mathrm{Rem} / \mu \mathrm{Ci}\end{array}$ & $\begin{array}{l}\text { Inhalation } \mathrm{DCF}^{\mathrm{b}} \\
\mathrm{Rem} / \mu \mathrm{Ci}\end{array}$ \\
\hline
\end{tabular}

\begin{tabular}{rrr}
$\mathrm{I}-129$ & $2.8 \mathrm{E}-01 \quad 1.8 \mathrm{E}-01$ \\
\hline
\end{tabular}

a Fifty-year EDEs from USDOE 1988; when values are given for more than one GI-tract absorption fraction, value corresponding to higher absorption fraction is adopted.

b Fifty-year EDEs from USDOE 1988; when more than one DCF is given for different lung clearance classes, the clearance class giving the highest DCF is selected, except as noted.

Table B.3-3 External Dose-Rate Conversion Factors for Radionuclides Uniformly Distributed in $15 \mathrm{Cm}$ of Surface Soil

Radionuclide Rem/yr per $\mathrm{uCi} / \mathrm{m}^{3 \mathrm{a}}$

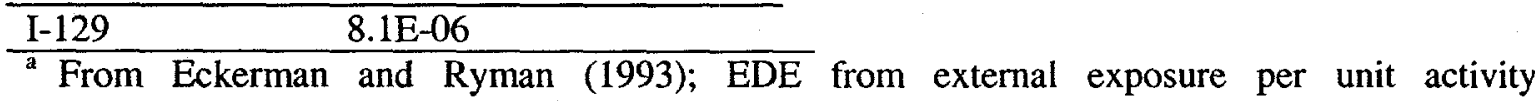
concentration in soil at distance of $1 \mathrm{~m}$ from source region.

Table B.3-4 External Dose-Rate Conversion Factors for Radionuclides Uniformly Distributed in Infinite Thickness of Soil-Equivalent Material

\begin{tabular}{llll}
\hline Radionuclide & $\begin{array}{l}\text { Dose-rate factor } \\
\text { No shielding }\end{array}$ & $\begin{array}{l}\text { Dose-rate factor } \\
\text { Rem } / \text { yr per } \mu \mathrm{Ci} / \mathrm{m}^{3}\end{array}$ & $\begin{array}{l}\text { Dose-rate factor } \\
\text { Rem shielding }\end{array}$ \\
& Re per $\mu \mathrm{Ci} / \mathrm{m}^{3}$ & $\begin{array}{l}100 \mathrm{~cm} \text { shielding } \\
\text { Rem } / \mathrm{yr} \text { per } \mu \mathrm{Ci} / \mathrm{m}^{3}\end{array}$ \\
\hline $\mathrm{I}-129$ & $8.1 \mathrm{E}-06$ & -- & -- \\
\hline
\end{tabular}

${ }^{a}$ From Eckerman and Ryman (1993); EDE rates from external exposure per unit activity concentration in soil at distance of $1 \mathrm{~m}$ from source region.

b Represent EDE rates from external exposure per unit activity concentration in soil at distance of $1 \mathrm{~m}$ from source region; are based on calculations for monoenergetic photon sources (Kocher and Sjoreen 1985) and energies and intensities of photons emitted in decay of radionuclides (Kocher 1981).

Table B.3-5 Annual EDEs from Drinking Water Pathway Per Unit Concentration of Radionuclides in Water

\begin{tabular}{ll}
\hline Radionuclide & EDE \\
& rem/yr per $\mu \mathrm{Ci} / \mathrm{L}$ \\
\hline $\mathrm{I}-129$ & $2.0 \mathrm{E}+02$ \\
\hline
\end{tabular}


Table B.3-6 Elemental Plant-to-Soil Concentration Ratios in Vegetables

Element $B_{v}{ }^{a, b}$

$\frac{\mathrm{I}}{\mathrm{a} \mu \mathrm{Ci} / \mathrm{kg} \text { fresh weight in vegetation per } \mu \mathrm{Ci} / \mathrm{kg} \text { dry weight in soil. }}$

b Except as noted, values are based on concentration ratios reported on basis of dry weight of vegetation given in Fig. 2.2 of Baes et al. (1984) multiplied by a factor of 0.43 to convert to fresh weight of vegetation (Baes et al. 1984).

Table B.3-7 Annual EDEs from Vegetable Pathway Per Unit Concentration of Radionuclides in Exhumed Waste for Agriculture Scenario

\begin{tabular}{ll}
\hline Radionuclide & $\begin{array}{l}\text { EDE } \\
\left(\mathrm{rem} / \mathrm{yr} \text { per } \mu \mathrm{Ci} / \mathrm{m}^{3}\right)\end{array}$ \\
\hline $\mathrm{I}-129$ & $7.9 \mathrm{E}-05$ \\
\hline
\end{tabular}

Table B.3-8 Annual EDEs from Soil Ingestion Pathway Per Unit Concentration of Radionuclides in Exhumed Waste for Agriculture Scenario

\begin{tabular}{ll}
\hline Radionuclide & $\begin{array}{l}\text { EDE } \\
\left(\mathrm{rem} / \mathrm{yr} \operatorname{per} \mu \mathrm{Ci} / \mathrm{m}^{3}\right)\end{array}$ \\
\hline $\mathrm{I}-129$ & $1.5 \mathrm{E}-06$ \\
\hline
\end{tabular}

Table B.3-9 Annual EDEs From External Exposure in Vegetable Garden Per Unit

\begin{tabular}{ll} 
& Concentration of Radionuclides in Exhumed Waste for Agriculture \\
\hline Radionuclide & $\begin{array}{l}\mathrm{EDE} \\
\left(\mathrm{rem} / \mathrm{yr} \mathrm{per} \mu \mathrm{Ci} / \mathrm{m}^{3}\right)\end{array}$ \\
\hline $\mathrm{I}-129$ & $1.6 \mathrm{E}-08$ \\
\hline
\end{tabular}

Table B.3-10 Annual EDEs from External Exposure in Home Per Unit Concentration of Radionuclides in Disposal Units for Agriculture Scenario

\begin{tabular}{ll}
\hline Radionuclide & $\begin{array}{l}\text { EDE } \\
\left(\mathrm{rem} / \mathrm{yr} \operatorname{per} \mu \mathrm{Ci} / \mathrm{m}^{3}\right)\end{array}$ \\
\hline $\mathrm{I}-129$ & $2.8 \mathrm{E}-06$ \\
\hline
\end{tabular}

Table B.3-11 Annual EDEs from Inhalation Exposure in Vegetable Garden Per Unit \begin{tabular}{lcc} 
& Concentration of Radionuclides in Exhumed Waste for Agriculture Scenario \\
\hline Radionuclide & EDE
\end{tabular} I-129 $\left(\mathrm{rem} / \mathrm{yr}\right.$ per $\left.\mu \mathrm{Ci} / \mathrm{m}^{3}\right)$

$2.1 \mathrm{E}-10$


Table B.3-12 Annual EDEs from Inhalation Exposure in Home Per Unit Concentration of Radionuclides in Disposal Units for Agriculture Scenario

\begin{tabular}{ll}
\hline Radionuclide & $\begin{array}{l}\text { EDE } \\
\left(\text { rem } / \text { yr per } \mu \mathrm{Ci} / \mathrm{m}^{3}\right)\end{array}$ \\
\hline $\mathrm{I}-129$ & $5.1 \mathrm{E}-09$ \\
\hline
\end{tabular}

Table B.3-13 Annual EDEs Per Unit Concentration of Radionuclides in Disposal Units from All Exposure Pathways for Agriculture Scenario

\begin{tabular}{ll}
\hline Radionuclide & $\begin{array}{l}\mathrm{EDE} \\
\left(\mathrm{rem} / \mathrm{yr} \text { per } \mu \mathrm{Ci} / \mathrm{m}^{3}\right)\end{array}$ \\
\hline $\mathrm{I}-129$ & $8.4 \mathrm{E}-05$ \\
\hline
\end{tabular}

Table B.3-14 Annual EDEs Per Unit Concentration of Radionuclides in Disposal Units for Resident Scenario

\begin{tabular}{|c|c|c|}
\hline \multirow[b]{2}{*}{ Radionuclide } & \multicolumn{2}{|l|}{$\mathrm{EDE}\left(\mathrm{rem} / \mathrm{yr}\right.$ per $\left.\mu \mathrm{Ci} / \mathrm{m}^{3}\right)$} \\
\hline & No Shielding $^{2} \quad 45 \mathrm{~cm}$ shielding ${ }^{\mathrm{b}}$ & $100 \mathrm{~cm}$ shielding ${ }^{\mathrm{c}}$ \\
\hline $\mathrm{I}-129$ & $2.8 \mathrm{E}-06$ & $-\cdots+$ \\
\hline \multicolumn{3}{|c|}{$\begin{array}{l}\text { Results apply to all disposal unit at times when engineered barriers which provide shielding } \\
\text { above the waste are assumed to have lost their physical integrity. }\end{array}$} \\
\hline \multicolumn{3}{|c|}{$\begin{array}{l}\text { Results apply to LAW vaults at } 100 \text { years after facility closure, when the roofs of the vaults are } \\
\text { assumed to be intact and residence on unshielded waste is not credible. }\end{array}$} \\
\hline \multicolumn{3}{|c|}{$\begin{array}{l}\text { c Results apply to } \mathrm{IL} \text { vaults at } 100 \text { years after facility closure, when the roofs of the vaults and } \\
\text { uncontaminated grout layer over the waste are assumed to be intact and residence on }\end{array}$} \\
\hline
\end{tabular}

Table B.3-15 Annual EDEs Per Unit Concentration of Radionuclides in Exhumed Waste for Post-Drilling Scenario

\begin{tabular}{ll}
\hline Radionuclide & $\begin{array}{l}\text { EDE } \\
\left(\mathrm{rem} / \mathrm{yr} \text { per } \mu \mathrm{Ci} / \mathrm{m}^{3}\right)\end{array}$ \\
\hline $\mathrm{I}-129$ & $8.1 \mathrm{E}-06$ \\
\hline
\end{tabular}


Table B.3-16 Summary of All Scenario Dose Conversion Factors (SDCF) for I-129 for Inadvertent Intruder Cases

\begin{tabular}{|c|c|c|c|c|c|c|c|c|c|c|c|c|c|c|}
\hline SCENARIO & SDCF & DCF & uw & uv & us & ua & Biv & La & ug & us & fa & fs & $\mathbf{s}$ & deltas \\
\hline Offsite:Water & $2.0 E+02$ & 0.28 & 730 & & & & & & & & & & & \\
\hline Ag:Vegetable & 7.9E-05 & 0.28 & & 90 & & & 2.2E-02 & & & & & 0.2 & & 1400 \\
\hline Ag:Soil & 1.5E-06 & 0.28 & & & 3.7E-02 & & & & & & & 0.2 & & 1400 \\
\hline Ag:ExtGarden & 1.6E-08 & 8.1E-06 & & & & & & & 0.01 & & & 0.2 & & \\
\hline Ag:AirGarden & 2.1E-10 & 0.18 & & & & 8000 & & $1.0 \mathrm{E}-07$ & & & 0.01 & 0.2 & & 1400 \\
\hline Ag:ExtHouse & 2.8E-06 & 8.1E-06 & & & & & & & & 0.5 & & & 0.7 & \\
\hline $\begin{array}{l}\text { Ag:AirHouse } \\
\text { Ag:All }\end{array}$ & $\begin{array}{l}\text { 5.1E-09 } \\
8.4 E-05\end{array}$ & 0.18 & & & & 8000 & & $1.0 \mathrm{E}-08$ & & & 0.5 & 1 & & 1400 \\
\hline Res:ExtHouse & 2.8E-06 & & & & & & & & & & & & & \\
\hline $\begin{array}{l}\text { Ag:Subtotal- } \\
\text { NoHouse }\end{array}$ & 8.1E-05 & & & & & & & & & & & & & \\
\hline PostDrill:All & 8.1E-06 & & sam & ie as & Ag:Sub & otalNc & House, $b$ & ut soil mi) & xing (f & fs) of & 0.02 & rath & r the & an 0.2 \\
\hline
\end{tabular}

Note: SDCF calculated by multiplying all nonzero factors, except that "deltas" is a nonzero divisor 
Table B.3-17. Summary of Radionuclide-Independent Parameter Values Used in Dose Analyses for Off-Site Individuals and Inadvertent Intruders

\begin{tabular}{|c|c|c|}
\hline Parameter description & Symbol & Parameter value \\
\hline Consumption of contaminated drinking water ${ }^{a}$ & $\mathrm{U}_{\mathrm{w}}$ & $730 \mathrm{~L} /$ year \\
\hline Consumption of contaminated vegetables ${ }^{b}$ & $\mathrm{U}_{\mathrm{v}}$ & $90 \mathrm{~kg}$ (fresh weight) per year \\
\hline Density of soil ${ }^{\mathrm{b}}$ & $\rho_{\mathrm{s}}$ & $1,400 \mathrm{~kg} / \mathrm{m}^{3}$ \\
\hline $\begin{array}{l}\text { Dilution factor for mixing of exhumed waste } \\
\text { with native soil in vegetable garden }\end{array}$ & $f_{s}$ & $\begin{array}{l}0.2^{\mathrm{c}} \\
0.02^{\mathrm{d}}\end{array}$ \\
\hline Consumption of contaminated soil ${ }^{\mathrm{b}}$ & $\mathrm{U}_{\mathrm{s}}$ & $0.037 \mathrm{~kg} /$ year \\
\hline $\begin{array}{l}\text { Exposure times - } \\
\text { working in garden } \\
\text { residing in home }\end{array}$ & $\begin{array}{l}\mathrm{U}_{\mathrm{g}} \\
\mathrm{U}_{\mathrm{h}}\end{array}$ & $\begin{array}{l}1 \% \text { per year } \\
50 \% \text { per year }\end{array}$ \\
\hline $\begin{array}{l}\text { Shielding factor for external exposure during } \\
\text { indoor residence }\end{array}$ & $S$ & 0.7 \\
\hline Air intake (breathing rate) ${ }^{b}$ & $\mathrm{U}_{\mathrm{a}}$ & $8,000 \mathrm{~m}^{3} /$ year \\
\hline $\begin{array}{l}\text { Atmospheric mass loading of contaminated } \\
\text { surface soil - } \\
\text { working in garden } \\
\text { residing in home } \\
\text { c }\end{array}$ & $\mathrm{L}_{\mathrm{a}}$ & $\begin{array}{l}10^{-7} \mathrm{~kg} / \mathrm{m}^{3} \\
10^{-8} \mathrm{~kg} / \mathrm{m}^{3}\end{array}$ \\
\hline
\end{tabular}

a Parameter applies to exposure of off-site individuals.

${ }^{b}$ Parameter applies to agriculture and post-drilling scenarios for inadvertent intruders.

${ }^{c}$ Parameter applies to agriculture scenario for inadvertent intruders.

d Parameter applies to post-drilling scenario for inadvertent intruders.

e Parameter applies to agriculture and resident scenarios for inadvertent intruders. 
APPENDIX C

RESULTS OF FLOW AND TRANSPORT MODELING

Rev. 1 
THIS PAGE INTENTIONALLY LEFT BLANK

Rev. 1 


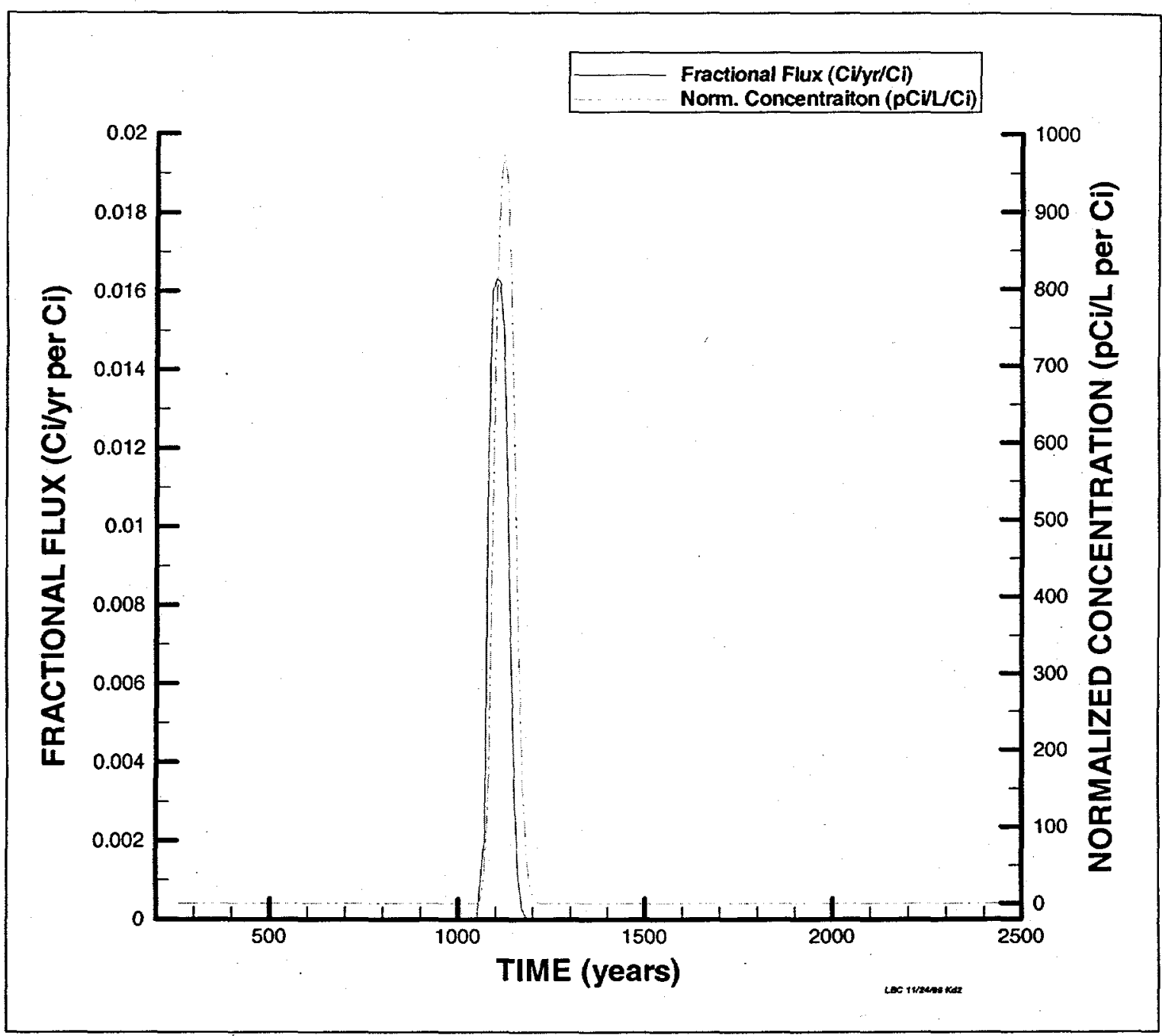

Figure C-1. Hypothetical waste (Kd=2 ml/g): PORFLOW predicted I-129 fractional release ( $\mathrm{Ci} / \mathrm{year} / \mathrm{Ci}$ inventory) to the water table and normalized concentration $(\mathrm{pCi} / \mathrm{L} / \mathrm{Ci}$ inventory) at the 100-meter well for the Intermediate Level Vaults 


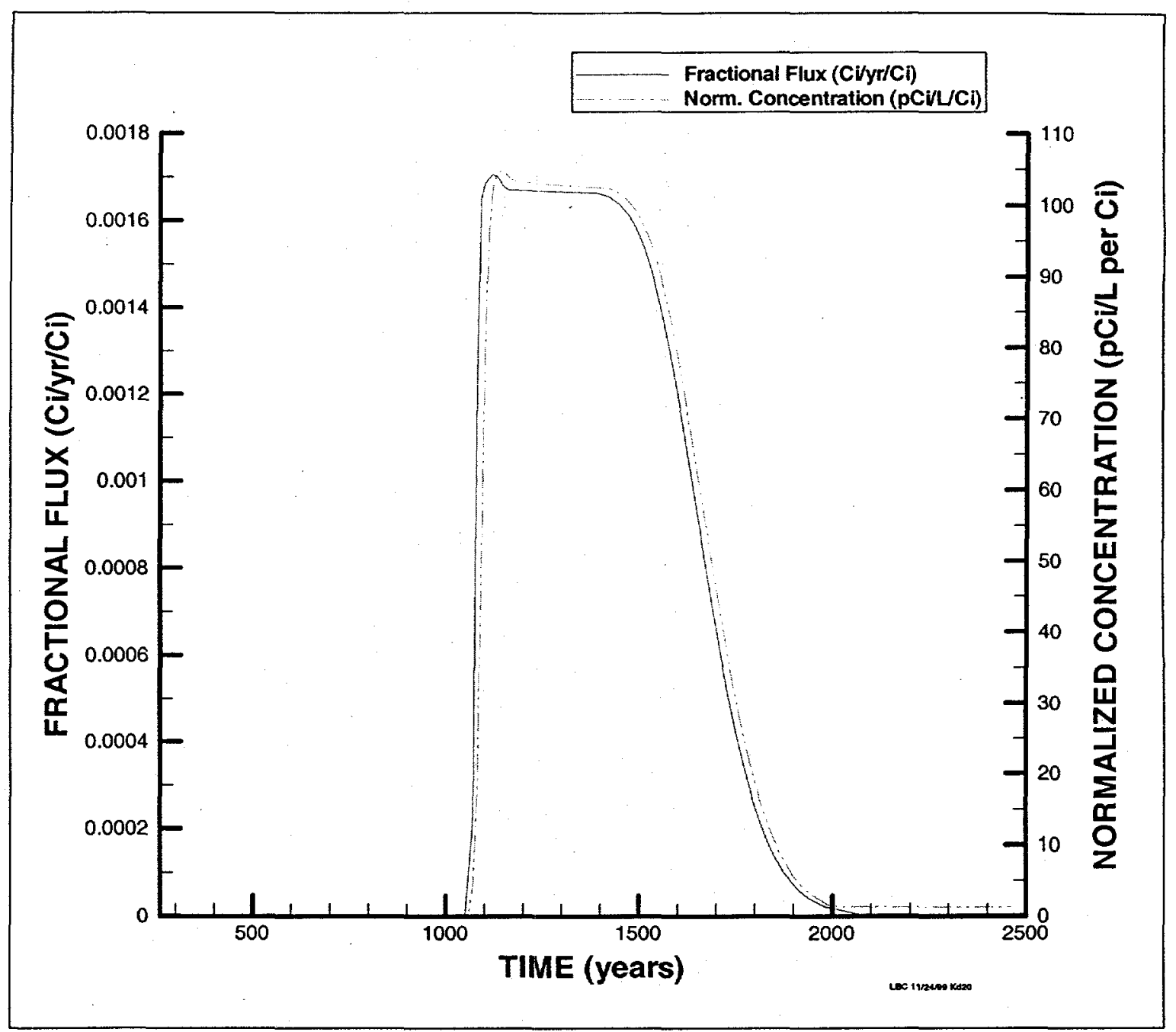

Figure C-2. Hypothetical Waste (Kd=20 ml/g): PORFLOW predicted I-129 fractional release $(\mathrm{Ci} /$ year/Ci inventory) to the water table and normalized concentration $(\mathrm{pCi} / \mathrm{L} / \mathrm{Ci}$ inventory) at the 100-meter well for the Intermediate Level Vaults 


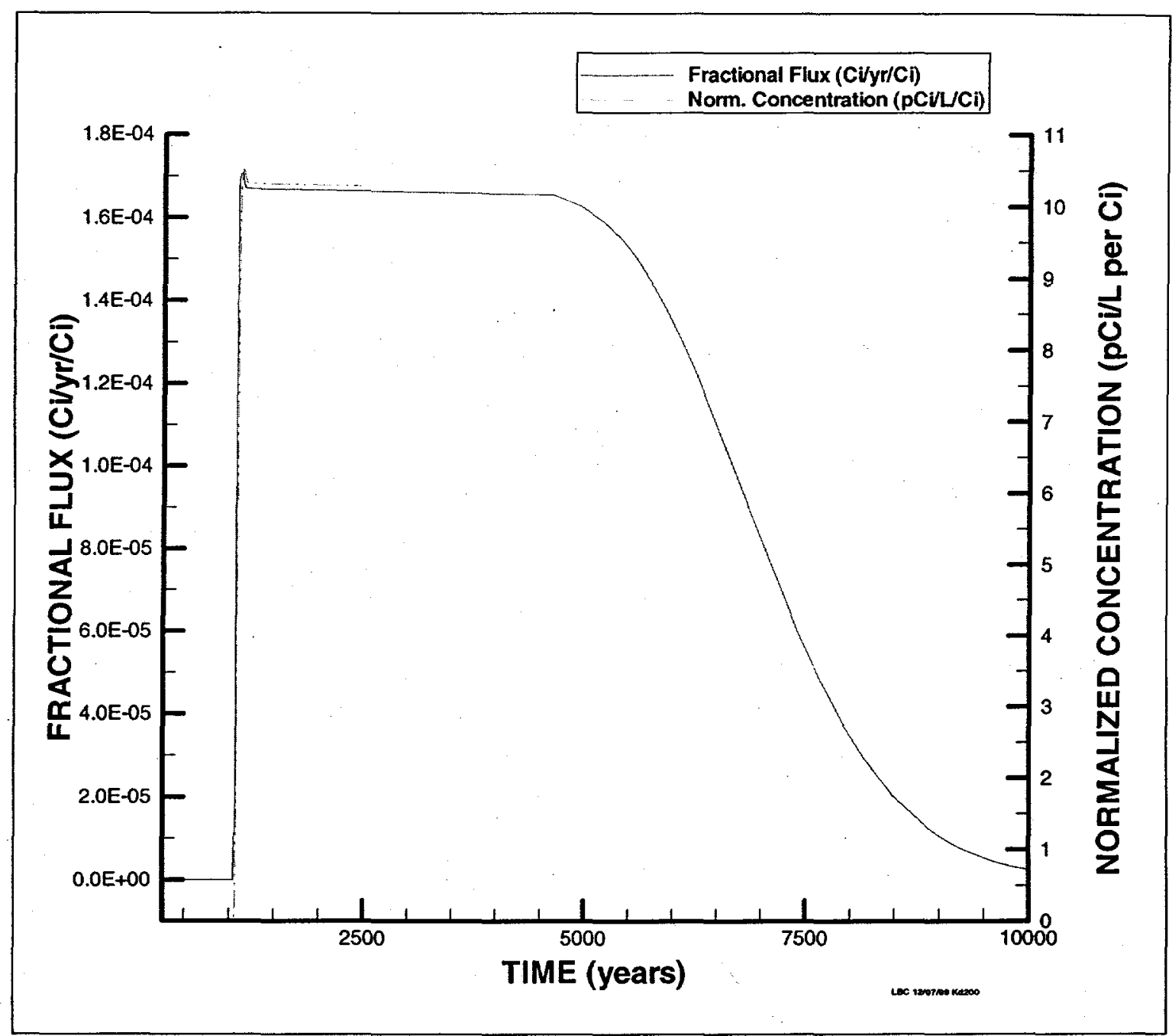

Figure C-3. Hypothetical Waste (Kd=200 ml/g): PORFLOW predicted I-129 fractional release ( $\mathrm{Ci} / \mathrm{year} / \mathrm{Ci}$ inventory) to the water table and normalized concentration $(\mathrm{pCi} / \mathrm{L} / \mathrm{Ci}$ inventory) at the 100-meter well for the Intermediate Level Vaults 


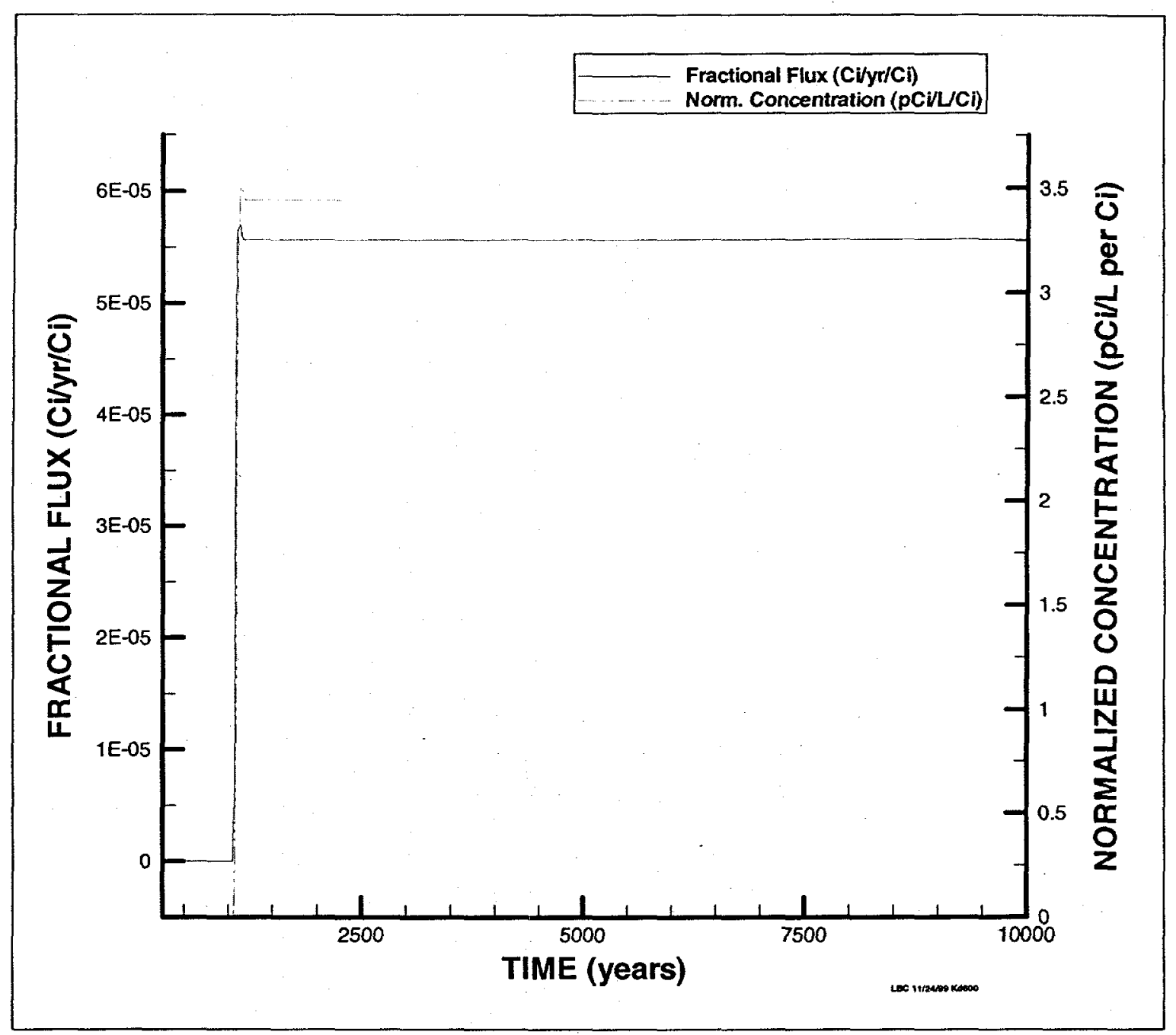

Figure C-4. Activated Carbon (Kd=600 ml/g): PORFLOW predicted $1-129$ fractional release $(\mathrm{Ci} / \mathrm{year} / \mathrm{Ci}$ inventory) to the water table and normalized concentration $(\mathrm{pCi} / \mathrm{L} / \mathrm{Ci}$ inventory) at the 100-meter well for the Intermediate Level Vaults 


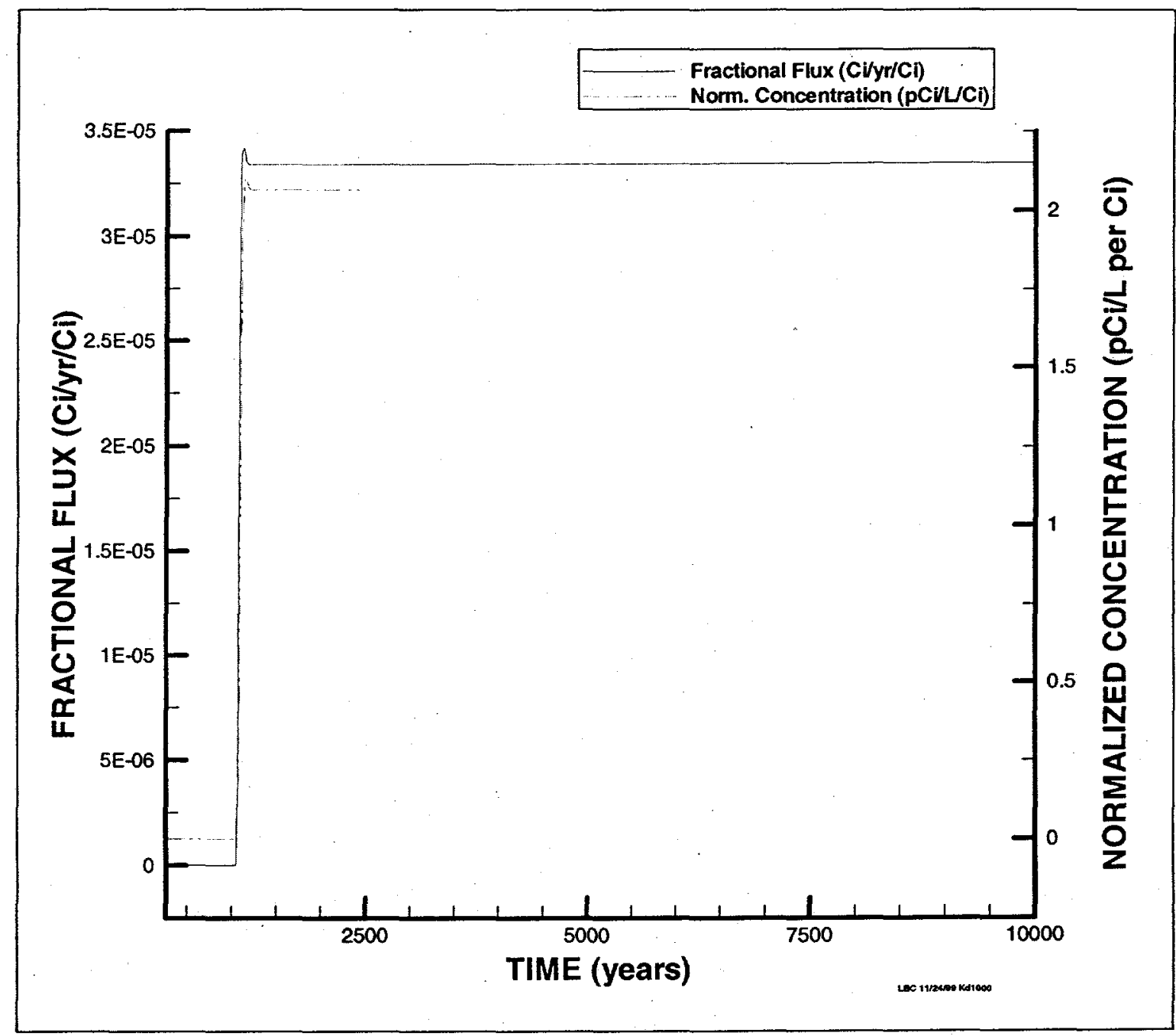

Figure C-5. Hypothetical Waste $(\mathrm{Kd}=1000 \mathrm{ml} / \mathrm{g})$ : PORFLOW predicted $\mathrm{I}-129$ fractional release $(\mathrm{Ci} /$ year/ $\mathrm{Ci}$ inventory) to the water table and normalized concentration $(\mathrm{pCi} / \mathrm{L} / \mathrm{Ci}$ inventory) at the 100-meter well for the Intermediate Level Vaults 


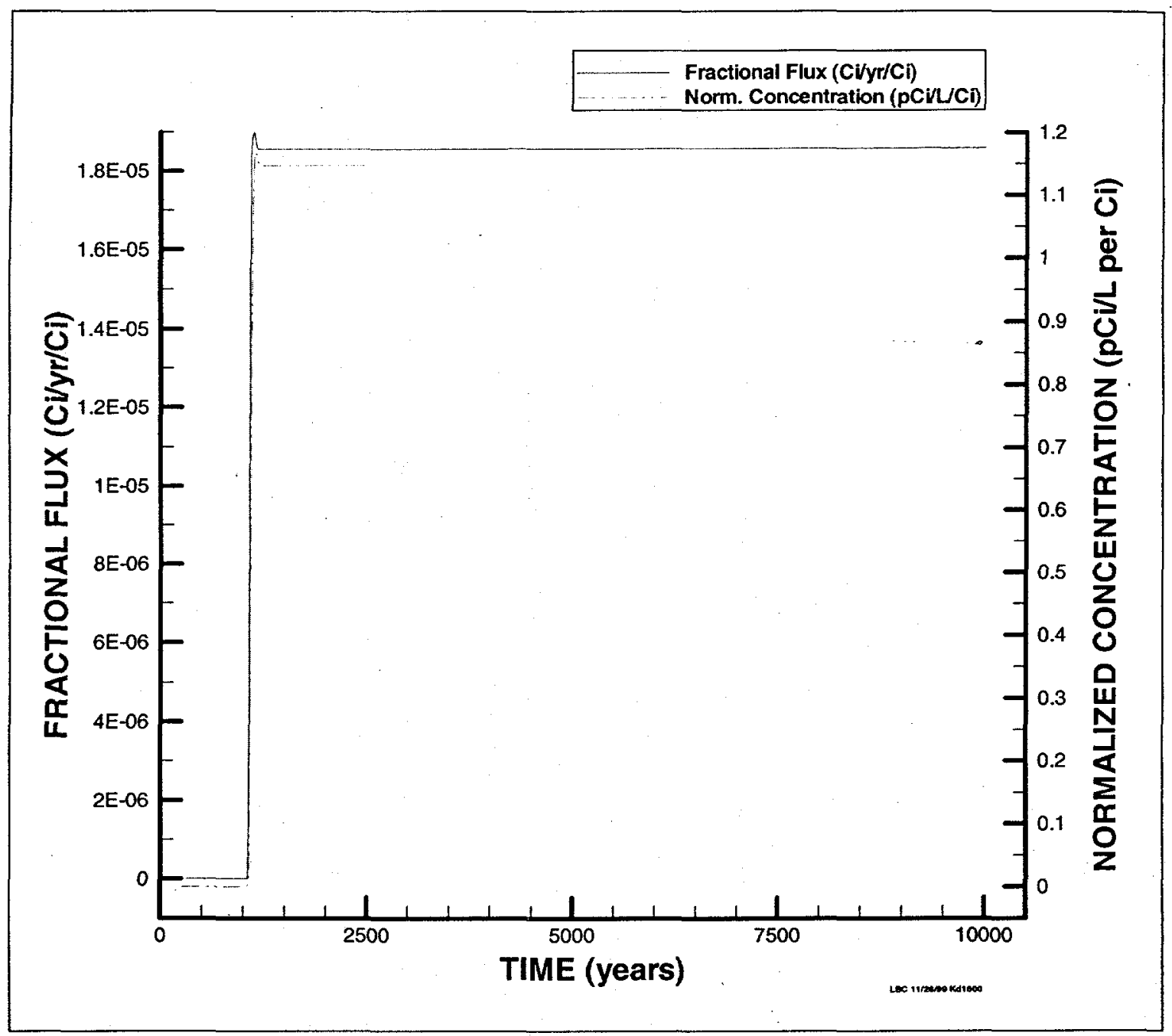

Figure C-6. Dowex 21K Resin ${ }^{a}(\mathrm{Kd}=2800 \mathrm{ml} / \mathrm{g})$ : PORFLOW predicted I-129 fractional release $(\mathrm{Ci} / \mathrm{year} / \mathrm{Ci}$ inventory) to the water table and normalized concentration $(\mathrm{pCi} / \mathrm{L} / \mathrm{Ci}$ inventory) at the 100-meter well for the Intermediate Level Vaults

${ }^{\mathrm{a}}$ Not planned for disposal in IL Vaults 


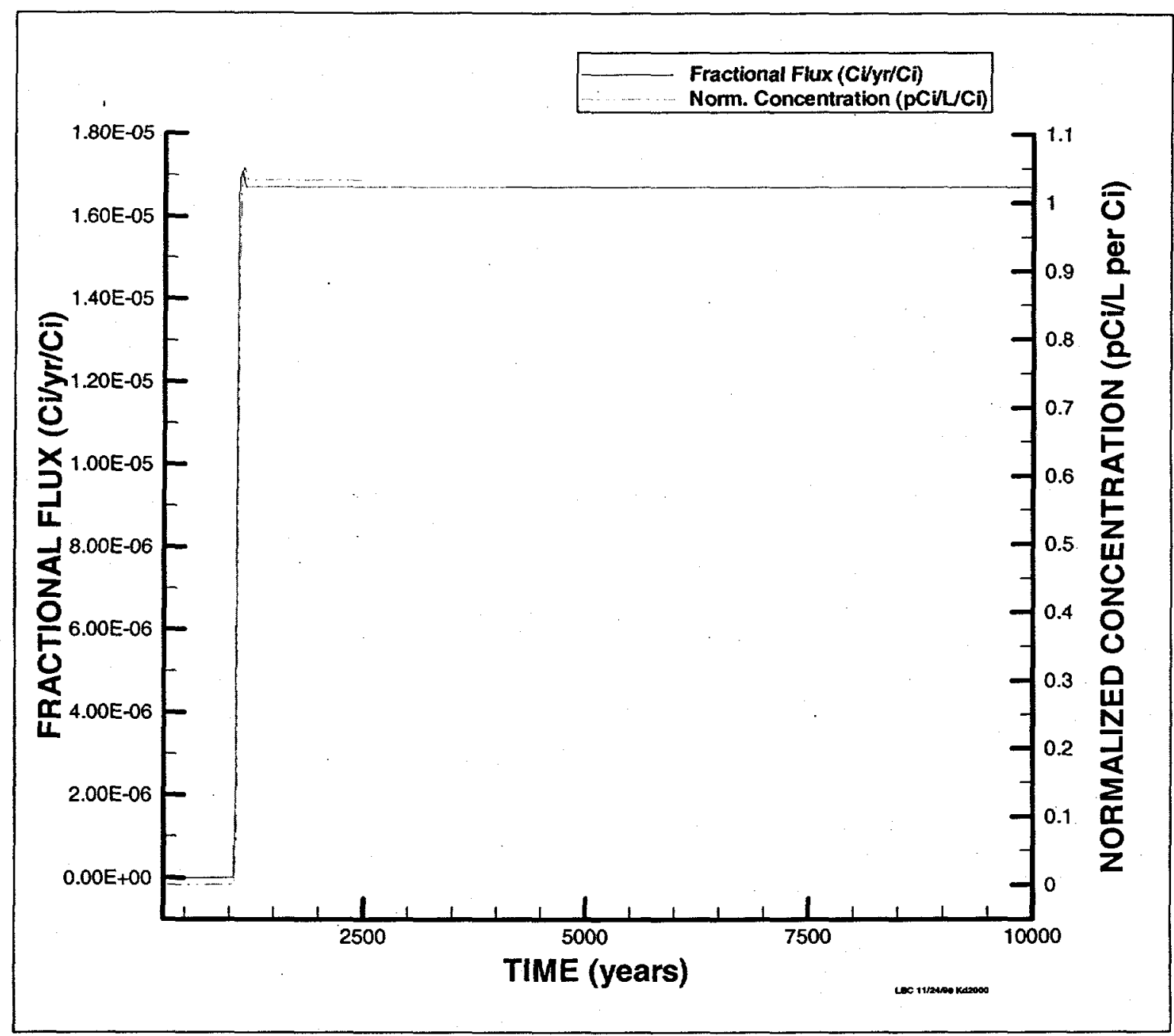

Figure C-7. Hypothetical Waste $(\mathrm{Kd}=2000 \mathrm{ml} / \mathrm{g})$ : PORFLOW predicted $\mathrm{I}-129$ fractional release $(\mathrm{Ci} / \mathrm{year} / \mathrm{Ci}$ inventory) to the water table and normalized concentration $(\mathrm{pCi} / \mathrm{L} / \mathrm{Ci}$ inventory) at the 100-meter well for the Intermediate Level Vaults 


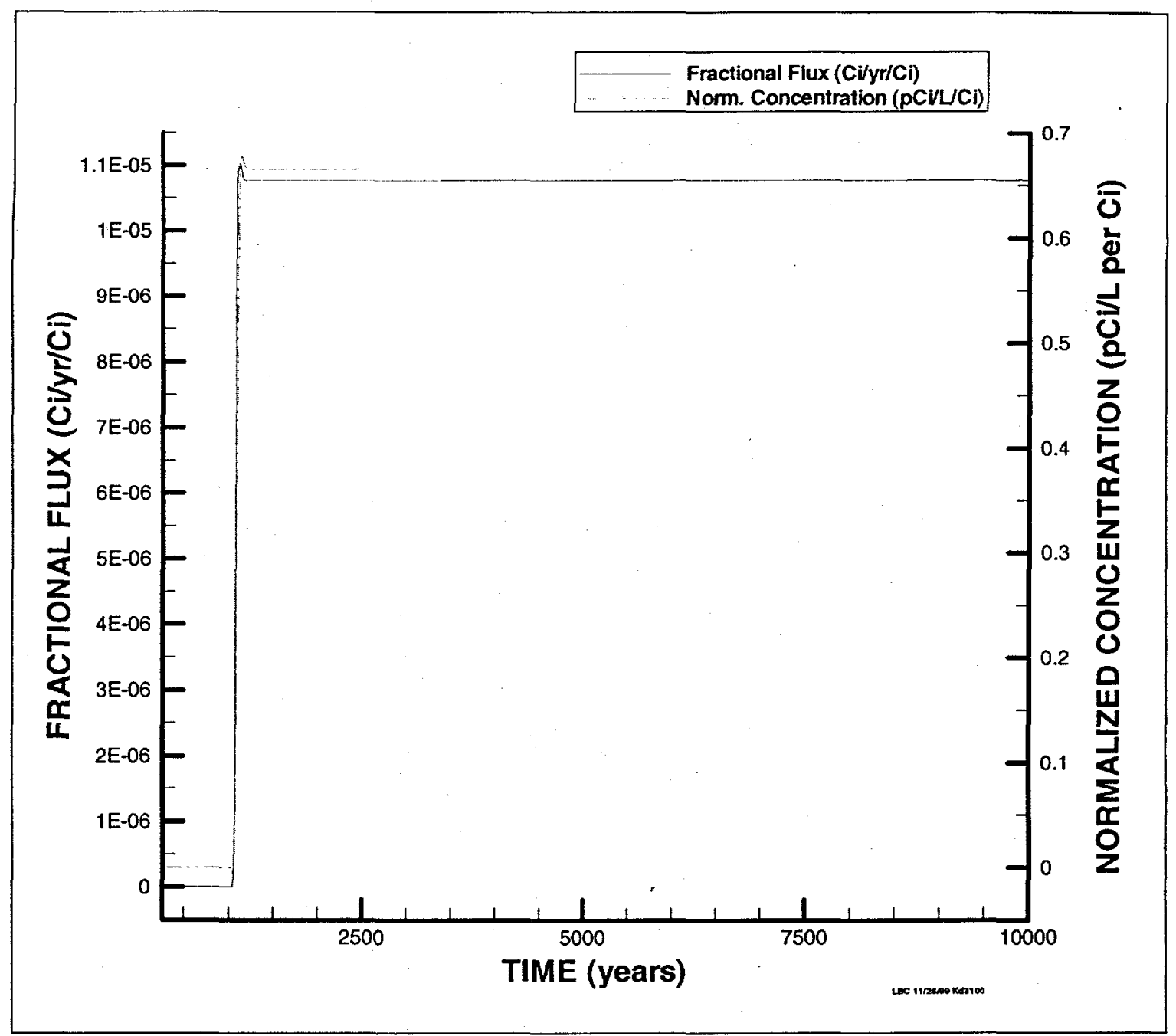

Figure C-8. GT-73 $(\mathrm{Kd}=3100 \mathrm{ml} / \mathrm{g})$ : PORFLOW predicted $\mathrm{I}-129$ fractional release ( $\mathrm{Ci} /$ year/ $\mathrm{Ci}$ inventory) to the water table and normalized concentration $(\mathrm{pCi} / \mathrm{L} / \mathrm{Ci}$ inventory) at the 100-meter well for the Intermediate Level Vaults

${ }^{a}$ Not planned for disposal in $\Pi$ Vaults 